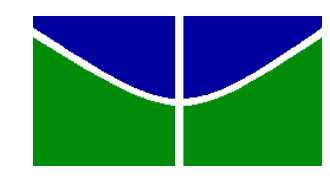

Universidade de Brasília

Faculdade de Educação

Programa de Pós-Graduação em Educação

FERNANDA FAGUNDES ALVES

AS QUESTÕES SOCIOAMBIENTAIS REVELADAS

A PARTIR DAS PERCEPÇÕES DAS CRIANÇAS SOBRE

A CIDADE ESTRUTURAL (DF) EM UM CONTEXTO EDUCATIVO

BRASÍLIA 


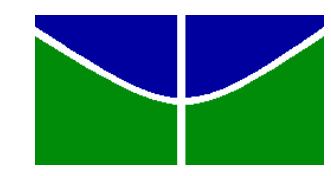

Universidade de Brasília

Faculdade de Educação

Programa de Pós-Graduação em Educação

FERNANDA FAGUNDES ALVES

AS QUESTÕES SOCIOAMBIENTAIS REVELADAS

A PARTIR DAS PERCEPÇÕES DAS CRIANÇAS SOBRE

A CIDADE ESTRUTURAL (DF) EM UM CONTEXTO

EDUCATIVO

Dissertação apresentada à banca examinadora do Programa de PósGraduação em Educação da Faculdade de Educação da Universidade de Brasília/UnB como parte dos requisitos para obtenção do título de Mestre, sob a orientação da professora Pós-Doutora Claudia Márcia Lyra Pato.

BRASÍLIA

2012 


\title{
AS QUESTÕES SOCIOAMBIENTAIS REVELADAS A PARTIR DAS PERCEPÇÕES DAS CRIANÇAS SOBRE A CIDADE ESTRUTURAL (DF) EM UM CONTEXTO EDUCATIVO
}

\begin{abstract}
Dissertação apresentada à banca examinadora do Programa de PósGraduação em Educação da Faculdade de Educação da Universidade de Brasília/UnB como parte dos requisitos para obtenção do título de Mestre, sob a orientação da professora Pós-Doutora Claudia Márcia Lyra Pato.
\end{abstract}

Aprovada em 29 de Outubro de 2012

BANCA EXAMINADORA

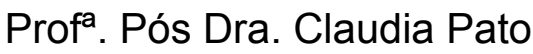

Universidade de Brasília

Profa. Dra. Rosângela Azevedo Corrêa

Universidade de Brasília

Profa. Dra. Maria Inês Gasparetto Higuchi

Universidade Federal de Amazonas

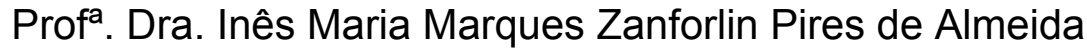

Universidade de Brasília 
Dedico este trabalho à querida "vó" Leonta, que partiu quando eu desenvolvia a pesquisa e hoje apenas a vejo em fotografias, mas ainda assim é minha referência no amar, cuidar, viver e a me conectar com o mais positivo dos seres. 


\section{AGRADECIMENTOS}

Agradeço à minha família de Minas: minha mãe e meu pai, que sempre me apoiam e me ensinam a amar incondicionalmente, à Elen e Guto, que me provocam a servir de exemplo e a lidar positivamente com os desafios da vida. Aos meus demais parentes, que sempre me mandam mensagens tão lindas.

Também agradeço aos meus irmãos de caminhada em Brasília, sem os quais também não teria chegado aqui (Gabs, Fabs, Carol, Leo, Daya, Tript, Belinha, Fer e Marina)

À minha orientadora, Claudia Pato, que me mostrou, pelo seu agir, qualidades essenciais a uma educadora, e também aos professores que contribuíram de forma decisiva nessa etapa de minha formação: Vera Catalão, Eda Henriques, Marcelo Feijó, Rosângela Correa, Inês Maria de Almeida, Fátima Machiushi. Agradeço igualmente aos meus colegas de grupo de pesquisa, que me acolheram e me ajudaram em momentos importantes.

A toda equipe do Coletivo da Cidade e às pessoas com as quais convivi pela Cidade Estrutural, meus amigos de luta, indignações e esperanças que me inspiraram muito. Também às mulheres especiais do Decanato de Extensão da UnB (Leo, Eli, Priscila, Dani, Marlene e Soninha) com quem tive a felicidade de trabalhar e que participaram de momentos importantes dessa minha trajetória.

$\mathrm{E}$, por último, mas não menos importante, agradeço às crianças que trilharam comigo esse percurso. 
“(..)Que seria do homem sem seus vestígios?

Como saberíamos dos avós, do rosto da infância de nossos filhos?

Que seria de nós sem a ancoragem no tempo que esgarça e destroi? Que seria de nós sem nossos baús de saudade e choro?

É a fotografia que segura relógios, Retorna calendários, Faz do passado presente, Num instante. Fala do retrato denunciador, da esperança sumida, dos amores acabados, cujas caras não mais se tocam. (...)Falada das lições nunca aprendidas, da esperança na razão sem razão. Fala fotografia! Dá notícias do homem, em seu difícil trajeto."

(HUMBERTO, 2000, p. 11) 


\section{RESUMO}

No atual contexto educativo, questões relativas à percepção ambiental dos sujeitos têm sido valorizadas tanto para compreensão dos processos de aprendizagem quanto para o desenvolvimento de metodologias que contribuem no enfrentamento de questões socioambientais que os envolvem e na formação de sujeitos ecológicos. Nessa perspectiva, este trabalho investiga a percepção ambiental de crianças moradoras da Cidade Estrutural - DF sobre o local onde vivem no que diz respeito a aspectos vinculados à questões socioambientais desveladas a partir da leitura de fotografias realizadas por elas em uma oficina educativa. A partir da análise de um total de 15 fotografias, selecionadas pelos participantes em meio a atividades pedagógicas, foram reveladas questões vinculadas à Cidade Estrutural - DF relativas à convivência familiar e comunitária, lazer, áreas verdes, infraestrutura urbana, mobilidade e resíduos sólidos que se constituíram em uma narrativa complexa ligadas às suas percepções da cidade.

Palavras-Chaves: Educação Ambiental, percepção ambiental, crianças 


\begin{abstract}
In the current educational context, issues regarding the environmental perception of the subject have been valued both in the understanding of the learning process and in the development of methodologies that contribute to resolve environmental issuesrelated to the formation of ecological subjects.

In this perspective, this research investigates the environmental perception of children living in Cidade Estrutural- DF about their city concerning environmental issues uncovered by the interpretation of photographs taken by them in an educational workshop.

From the analysis of a total of 15 photographs selected by participants, issues related to Cidade Estrutural - DF regarding family and community, leisure, green spaces, infrastructure urban, mobility and solid waste were revealed.

While the workshop unfolded, thesematters revealed as essencial parts of the life of the participants, in a complex storyline .
\end{abstract}

Key Words: environmental education, environmental perception, children. 


\section{LISTA DE FIGURAS}

Ilustração 1-Bicalho,M;Fagundes,F.A. Entrada do lixão da Estrutural. Imagem

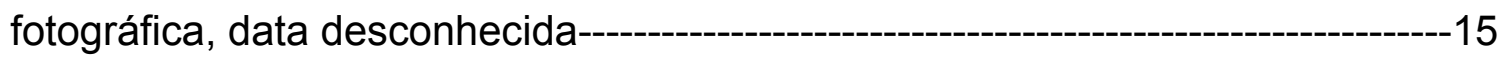

Ilustração 2-Imagem de satélite da Cidade Estrutural. Google, data de acesso 12 de junho de 2012

Ilustração 3-Fagundes, F.A. Mosaico de imagens selecionadas. Colagens com imagens fotográficas, 30 de outubro de 2012---_---llustração 4-Bia. Fael fofinho. Imagem fotográfica, 03 de maio de 2012 $-68$

Ilustração 5 - Pedro. Fofo. Imagem fotográfica, 07 de maio de 2012-------------69 Ilustração 6-Bia. Lugar ruim. Imagem fotográfica, 03 de maio de 2012------------$-71$

Ilustração 7- Fran.Criança na árvore. Imagem fotográfica, 07 de maio de 2012 72

Ilustração 8 - Yohanninha. Dentro do mato. Imagem fotográfica, 08 de maio de 2012$-73$

Ilustração 9 - Pedro. Cavaleiro fantasma. Imagem fotográfica, 08 de maio de 2012 $-75$

Ilustração 10- Fran.Criança livre. Imagem fotográfica, 08 de maio de 2012------76 Ilustração 11 - Yohanninha. Folhas verdes. Imagem fotográfica, 08 de maio de 2012 $-77$

Ilustração 12 - Bia. Flor Rosa. Imagem fotográfica, 03 de maio de 2012 $-78$

Ilustração 13 - Cassi. Plantas no chão. Imagem fotográfica, 03 de maio de 2012

Ilustração 14 - Cassi. Corrida. Imagem fotográfica, 03 de maio de 2012 --------80 Ilustração 15 - Cassi. Chão vermelho. Imagem fotográfica, 03 de maio de 2012---

Ilustração 16 - Fran. Lixo ruim na rua. Imagem fotográfica, 08 de maio de 2012 
Ilustração 17 - Pedro. Lixão. Imagem fotográfica, 08 de maio de 2012----------83

Ilustração 18 - Yohanninha. Lixo no campinho. Imagem fotográfica, 08 de maio

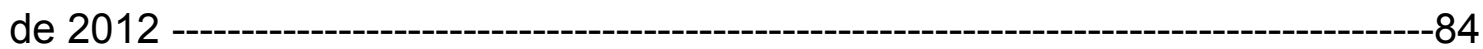




\section{LISTA DE TABELAS}

Tabela 1 - Foto, classificação, autor e questões socioambientais desveladas---$-55$ 


\section{SUMÁRIO}

1 CAMINHANDO PELA ESTRUTURAL: O QUE POSSO DIZER SOBRE MINHA TRAJETÓRIA

2 INTRODUÇÃO $-21$

3 OBJETIVOS 25

4 ASPECTOS LEGAIS E DE FORMAÇÃO DE SUJEITOS ECOLÓGICOS NA EDUCAÇÃO AMBIENTAL EM CONSONÂNCIA COM OS PROCESSOS PERCEPTIVOS DE QUESTÕES SOCIOAMBIENTAIS NAS CIDADES PARA GARANTIA DOS DIREITOS DAS CRIANÇAS E ADOLESCENTES26

5 MÉTODO $-36$

6 METODOLOGIA $-42$

6.1 Contexto $-42$

6.2 Sujeitos $-44$

6.3 Estratégia: Oficina Imagens da Cidade, fotografando o ambiente $-45$

6.4 Instrumentos46

6.5 Procedimentos$-47$

6.6 Trajetória percorrida na oficina imagens da cidade, fotografando o ambiente $-48$

6.7 Análise $-64$

7 AS QUESTÕES SOCIOAMBIENTAIS DA CIDADE ESTRUTURAL A

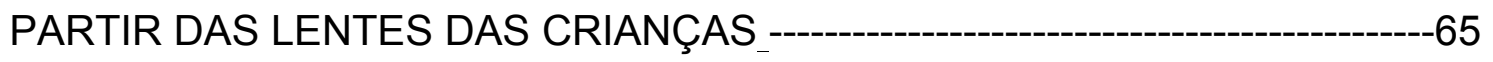

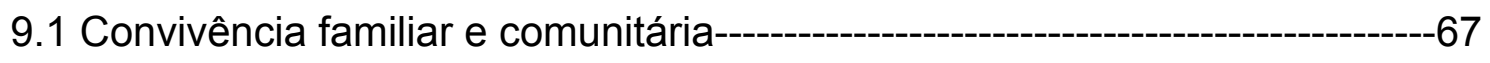

9.2 Convivência comunitária, lazer, áreas verdes e infraestrutura urbana_----72

9.3 Mobilidade, infraestrutura urbana e resíduos sólidos $-80$ 
8 CONSIDERAÇÕES FINAIS--



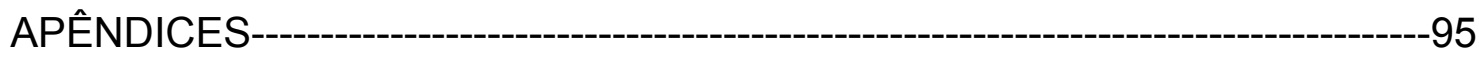




\section{CAMINHANDO PELA ESTRUTURAL: O QUE POSSO DIZER SOBRE MINHA TRAJETÓRIA}

Há um ditado popular que diz: "uma imagem vale mais que mil palavras". Alguns estudiosos vão discordar ao apontarem a supremacia da linguagem escrita ou mesmo ao trazerem o contexto atual da superexposição imagética para indicar que as nossas visões estão saturadas e que as imagens perderam sua força (BAITELO JÚNIOR, 2005). Mas aqui iremos confrontar essas abordagens, na medida em que a imagem fotográfica abaixo exposta é considerada para apresentar a minha trajetória na Cidade Estrutural que me motivou a realizar a pesquisa.

As imagens fotográficas são carregadas de potencialidades comunicativas, pois ao passo que carregam as características de certas formas de viver e pensar o mundo compartilhadas no âmbito de uma cultura, também revelam uma trama complexa e ambígua de representações das quais cada pessoa é tocada de forma distinta e interage de forma diferenciada com os elementos iconográficos presentes. No momento da leitura da imagem, diferentes narrativas se cruzam, abrindo caminhos para a conexão e a relação entre o eu, o tu e o nós dialogarmos.

A leitura das fotografias, dentre as possibilidades que se revelam, pode

envolver uma análise que tenha a descrição, a interpretação e a contextualização de aspectos do processo fotográfico e elaboração das imagens mentais. Esta análise poderá provocar uma síntese que possibilitará a recriação de novas sensações e novas formas de se pensar e/ou a corroboração de outras, tendo como referência a experiência anterior do(a) leitor(a) e os fatores que condicionam nosso olhar. Assim, o que é visto nas fotografias é transformado em imagens mentais que vão contribuir para posicionar os leitores no mundo diante de fenômenos que, nesse caso, envolvem a minha trajetória na Cidade Estrutural.

Dessa forma, juntos, vejamos a imagem abaixo. Você leitor (a), está convidado(a) a participar comigo nessa construção em que nós, oportunizados 
por uma relação intersubjetiva fenomenológica e histórica de abertura ao outro, poderemos dialogar. Nesse momento, ser-nos-á possível admirar um mesmo mundo, ou nos espantarmos com ele, afastarmos dele e com ele coincidirmos, colocando-nos e nos opondo (FREIRE, 1967, 1988). Um mundo relacionado ao vivido por mim nesse percurso de trabalho do qual a pesquisa de mestrado oferece elementos para qualificar uma prática educativa em contínua construção.



Ilustração 1- Bicalho, Marina, S; Fagundes, F.A. Entrada do lixão da Estrutural. Imagem fotográfica, data desconhecida.

$\mathrm{Na}$ foto, há uma cerca que delimita o local onde é depositado o lixo do Distrito Federal, conhecido como o lixão da Estrutural. Optei nesse trabalho em usar o termo lixão da Estrutural por ser a forma como que as pessoas que convivi se referem ao local e também pelo mesmo não ter um sistema de tratamento de chorume adequado e impermeabilização do solo para evitar a contaminação do mesmo como em um aterro controlado. 
Por trás da cerca, no chão de terra crua e seca, cheio do entulho e outros lixos, um ipê brota e colore o ambiente com leveza, com suas flores rosa. Algumas outras árvores ao fundo podem ser vistas, mas não se destacam na paisagem de terra e lixo. O ipê sim.

Ainda que agora ele se destaque na fotografia, por meses havia passado despercebido por mim, até o dia do registro fotográfico quando uma amiga que pela primeira vez circulada pela cidade o identificou e nós fizemos o registro.

Eu caminhava por ali diariamente e o que me chamava atenção era a insalubridade do local, com as ruas sem calçadas, cobertas de terra (ou lama quando em época de chuva), com intenso fluxo de caminhões carregando lixo. O ar era carregado de partículas de terra, dificultando a respiração, e de odor desagradável do chorume (resultante da decomposição da matéria orgânica do lixo).

Ver aquele ipê, ali naquele local, me despertou outras sensações. Vi mais beleza naquele cenário que se mantinha o mesmo em termos socioambientais, mas por um momento o destaque que eu fazia do odor desagradável e o desgosto de transitar a pé num lugar sem infraestrutura havia sido substituído por encantamento pelas flores e reconhecimento de que, mesmo naquele lugar, era possível ver a beleza da vida e das possibilidades que ela permite. A partir da experiência de andar pela cidade naquele dia e realizar o registro da imagem, comecei a confrontar alguns elementos que contribuíam para a formulação das minhas referências sobre o local e assim, o que eu pensava sobre o mesmo.

A foto foi tirada durante uma atividade do grupo de escoteiros da Cidade Estrutural da qual fomos convidadas para falar com os jovens e adolescentes sobre a questão ambiental. Esse evento tinha como objetivo prático percorrer o córrego da Cabeceira do Valo, que passa ali perto e está sendo impactado pela forma como a área está sendo ocupada, para, juntos, coletarmos lixo acumulado em suas margens. A proposta também envolvia trabalho de grupo e reflexão sobre a história da cidade, bem como questões ligadas à ocupação da terra e à preservação ambiental. 
As atividades do grupo de escotismo e outras, como oficinas de Educação Ambiental para crianças, formação para educadores sociais e eventos culturais, que também acompanhei durante o período de março de 2010 até junho de 2011, aconteciam no espaço da Associação Pró-vida estruturada - Associação Viver, localizada bem em frente à entrada do "lixão".

Tais atividades contribuíram para que nesse processo de registro do Ipê me fosse elaborado algumas questões. Assim como o ipê florido naquela paisagem inóspita não havia sido percebido, fiquei me indagando se outros elementos poderiam estar passando despercebidos por mim naquele lugar e contribuindo para condicionar a imagem mental que tinha da Cidade Estrutural.

Ademais, também me perguntei se eu não estaria confundindo alguns aspectos interessantes da conformação física do lugar e da forma com que as pessoas viviam ali com problemas, tendo uma compreensão reduzida daquela realidade como na foto, onde o tronco do ipê se confunde com a estrutura da cerca, com o entulho e com a camisa velha descartada. Esses questionamentos também foram reforçados pela minha vivência na localidade.

Ao passar pela rodovia DF-095 (Via estrutural), em que é possível ver a parte da cidade limítrofe à via, ainda que já com sinais dos investimentos para implantação de infraestrutura urbana, eu só conseguia enxergar os problemas relacionados à presença do lixão muito em função do trabalho que tinha antes de começar a minha inserção na Cidade Estrutural. Na época, recém-formada em Relações Internacionais e entusiasmada com as potencialidades do trabalho local mobilizatório, crítico e transformador da sociedade civil, estava trabalhando na Agenda Ambiental da Universidade de Brasília, vinculada ao Decanato de Extensão da Universidade e, por isso muito, sensível aos processos que envolviam a temática dos resíduos sólidos.

A questão dos resíduos sólidos pode ser considerada uma das grandes problemáticas socioambientais das cidades urbanas. Suas raízes remontam ao modelo capitalista de produção e consumo excessivo de bens supérfluos e descartáveis dentro da lógica de organização da sociedade atual, que está 
intimamente ligada à forma como a sociedade se relaciona e compreende a natureza e ao sentido atribuído à vida.

Nesse contexto, é gerado não apenas o rejeito material, como também o social, em que uma parcela da população em especial catadores de recicláveis e familiares é impactada de forma desigual pelos processos de degradação ambiental resultantes da destinação inadequada dos resíduos, muitas vezes fica desassistida de serviços como educação, saúde e previdência social (ZANETI, 2005).

Ainda que por meio da coleta de recicláveis seja possível se auferir renda, estabelecer um lugar de moradia e constituir uma família, bem como desenvolver uma prática que promova a emancipação dos sujeitos (COSTA, 2008), ações que garantam a vida digna e direitos básicos, como educação de qualidade para estes e seus familiares ainda se fazem necessárias.

Essas questões relacionadas à problemática dos resíduos sólidos me motivaram a iniciar um trabalho na Cidade Estrutural, uma vez que, a partir dos dados sociodemográficos aos quais tinha acesso e da paisagem do lugar, enxergava esta região como um exemplo do exposto acima. Minha primeira inserção na comunidade foi como voluntária de uma ação educativa de extensão universitária com adolescentes em 2009. Na ocasião, oferecemos um curso de audiovisual no qual, dentre as ações desenvolvidas, uma que se destacou: a exposição de imagens fotográficas feitas por eles ao transitarem pelas ruas da Cidade Estrutural. A proposta da exposição, sugerida pelos adolescentes, e que tinha como título Re-estrutural, era desmistificar imagem da cidade como um lugar de violência e lixo e mostrar que lá também era um lugar como qualquer outro, pois os participantes da atividade se incomodavam com o fato de, no Distrito Federal (DF), a veiculação na mídia sobre a cidade abordar basicamente abordar os temas da violência, pobreza e lixo e isso contribuir para o preconceito contra os que ali vivem.

Pela minha participação nessa atividade e em outras, já atuando com a equipe do Decanato de Extensão da Universidade de Brasília(DEX-UnB) junto à Associação Viver por meio de uma parceria com a entidade, e também atuando 
com coletivos na cidade de forma voluntária, pude começar a perceber que outras questões, que não se restringiam ao lixo e que tanto me sensibilizavam, movimentavam os que ali viviam e se mostravam a necessidade premente de uma mobilização. Ademais, o que, para mim, poderia ser um problema, para os que ali viviam poderia não ser. Aos poucos fui mudando meu olhar sobre a cidade.

Realizei oficinas para crianças atendidas pela Associação Viver, contribui no apoio pedagógico aos educadores sociais que lá trabalhavam. Também iniciei um trabalho de articulação e fomento a programas e projetos com vistas à sustentabilidade regional, bem como apoiei os moradores ameaçados de remoção da então quadra 12 no processo de mobilização e intervenção jurídica por meio de ação civil pública movida contra o governo do Distrito Federal.

No entanto, nesse percurso nem tudo foram flores e beleza como o ipê: vi a equipe da coordenação do trabalho da entidade parceira ser demitida por divergências, acompanhei de perto o drama de mães de família da quadra 12 sofrendo com ameaça de perder o local de moradia e com a desmobilização dos moradores do grupo que tinham instituído para fazer frente às arbitrariedades do governo e à corrupção na implantação do plano de estruturação da cidade. Aos poucos, meu entusiasmo foi passando e dando lugar a um sentimento de desilusão que me convidava a pensar melhor e me qualificar para continuar a atuação na comunidade.

Dessa vez, a mudança na forma pela qual eu pensava aquele local e interagia com ele, ou seja, a percepção ambiental da cidade havia sido provocada não por uma pessoa externa (como a minha amiga em relação ao ipê florido), mas pelos que viviam ali e estavam cotidianamente dentro da comunidade.

Assim como a garota da foto acima transita naquele local como se abrisse a bolsa após cruzar a rua, a cerca e o ipê, diante da minha vivência senti a necessidade de vasculhar minha bagagem, nesse caso, o meu viver na cidade $\mathrm{e}$ a minha busca por melhor elucidar questões vinculadas a esta cidade, em especial as atividades educativas que inter-relacionam à essas questões, tendo 
como referência a percepção ambiental dos que ali vivem. Com esse intuito ingressei no Mestrado em Educação.

Poderia ter apresentado o projeto na Psicologia, na Geografia, na Comunicação, pois a reflexão sobre questões que envolvem a vida na cidade e os desafios de um trabalho perpassam todos esses campos, mas trazer as contribuições destes para a Educação me pareceu mais significativo ao considerar as palavras de Gadotti:

Através da educação, os homens de uma época, de uma sociedade historicamente situada, se exprimem em relação àquilo que convém ser, que convém fazer e agem em consequência; nela é toda uma sociedade que se encontra empenhada, implicada. Na medida em que hoje em dia, a nossa sociedade esta em crise, se interroga e hesita, a educação torna-se, por sua vez, um lugar posto em questão, um lugar de tensão e debate. Nesse sentido, ela se constitui num espaço político-pedagógico e de liberdade, portanto, onde os homens preocupados em se situar podem lutar por uma existência mais autêntica e uma sociedade mais justa (GADOTTI, 1981, p 21).

Assim, sigamos juntos na leitura dessa dissertação, a partir de questões que se apresentam na introdução e integram a trajetória aqui apresentada, contribuindo dessa forma, para elucidação da mesma e em especial, o caminho que trilhamos durante a execução desse trabalho. 


\section{INTRODUÇÃO}

Como estudos têm apontado, as relações entre pessoa e ambiente são recíprocas, de influências mútuas e a visão dos sujeitos e grupos sociais e as inter-relações que eles estabelecem com seu entorno constituem dimensões fundamentais na produção dos espaços, no atendimento das demandas sociais, na elaboração de satisfação com o quadro da vida e nas condutas ambientais orientadas para ideários ecológicos (CARVALHO, 2008; KUHNEN, 2011; LYNCH $1956,1980)$. Isso porque a percepção que as pessoas tem influenciam a forma como estabelecem prioridades, avaliam e reconhecem os benefícios das ações nas cidades. Sendo assim, cada vez mais tem se procurado compreender a percepção ambiental dos sujeitos que criam imagens mentais, ou seja, referências formadas a partir da experiência em relação ao ambiente, a fim de se desenvolver programas e projetos com vistas à melhoria da qualidade de vida.

A percepção ambiental pode ser compreendida genericamente como uma forma de pensar o ambiente incluem elementos relacionados à cognição, afeto, significado, valoração e serve para elaboração de como as pessoas vivem o ambiente (KUHNEN, 2011). A percepção ambiental é um processo que diz respeito à elaboração de imagens mentais sobre o ambiente.Trata-se de um conceito analítico explorado no campo da Psicologia Ambiental, que tem contribuído para se entender processos que dizem respeito à apreensão do ambiente por parte dos sujeitos e sua atuação no mundo e consequentemente, também tem sido usado para se elucidar aspectos significativos da prática educativa ambiental, revelando os destaques para as questões sociambientais que mobilizam os sujeitos.

No contexto da Educação ambiental o ambiente das periferias dos grandes centros urbanos, como no Distrito Federal, tem sido apontados como marcado por processos de injustiça socioambiental dos quais uma parcela da população em situação de vulnerabilidade socioeconômica e política fica desassistida de serviços públicos como educação, transporte, saúde, saneamento e, com isso, também é mais impactada por processos de 
degradação ambiental vinculados às questões socioambientais que envolvem cada localidade(ASCELRAD; HERCULANO e PÁDUA,2004; LOPES , 2004; THEODORO e ASCELRAD, 2005). No Distrito Federal a Cidade Estrutural é apontada como um exemplo do expostos.

A Cidade Estrutural integra a XXV Região Administrativa do Distrito Federal. Surgiu com a instalação do "Lixão da Estrutural", na década de 60, após a inauguração de Brasília, com os primeiros "barracos" de catadores de material reciclável próximos ao local. Nessa dinâmica, cresceu com um grande adensamento populacional e, paradoxalmente, com precária urbanização, bem como déficit de habitação e de prestação de serviços públicos. Trata-se de uma localidade que além de ser impactada pela presença do lixão, encontra-se nas intermediações do Parque Nacional de Brasília e do Setor de Automóveis. Desde 2002, equipamentos públicos como escolas e serviços públicos como saneamento e pavimentação de ruas foram implantados no local a partir de um esforço de regularização da área e da urbanização muito embora nesse processo, conflitos vinculados às injustiças socioambientais enfrentadas pelos que moram na Cidade Estrutural tenham ocorridos.

Só que por mais que indicadores sociais( DISTRITO FEDERAL, 2004,2011) apontem elementos que corroboram com a afirmação de que as crianças, que residem nessa localidade, são impactadas por esses processos de injustiça socioambiental que ocorrem em seu ambiente-em suas casas, nas ruas e em outros locais, dependendo do contexto familiar e social, estão expostas às dinâmicas instituídas social e historicamente nas cidades em que vivempodemos indicar que elas estabelecem uma interação específica com o ambiente e com as questões socioambientais do lugar, uma vez que as imagens mentais, ou seja, referencias acerca da organização de aspectos significativos do mundo da vida dos sujeitos, obtidas a partir da percepção que elas têm do ambiente assumem um caráter específico que interfere na forma como pensam, vivem e agem.

O mundo da vida da criança urbana foi estudado de forma pioneira por Muchow e Muchow $(1935,1978)$. Os autores trouxeram a reflexão sobre a 
caracterização do espaço da experiência e da vida da criança urbana a partir da investigação de como as crianças pensam, experimentam e vivem o ambiente urbano, levando em consideração o ponto de vista delas. Como a autora aponta, a criança urbana está inserida em uma realidade específica que precisa ser estudada, tendo, inclusive, implicações pedagógicas os resultados de tais pesquisas.

Diante do exposto, a Educação Ambiental assume a função social de mediar uma reflexão, tendo como parâmetro a percepção dos sujeitos sobre a realidade vivenciada dentro de um esforço mobilizatório em prol do enfrentamento dos desafios que envolvem a vida da criança da periferia dos centros urbanos, vinculados aos processos de injustiça, e garantia de direitos.

Embora haja interesse de se incorporar a compreensão da percepção ambiental das crianças em processos pedagógicos mobilizatórios pela busca de direitos, há poucos estudos envolvendo crianças de periferias de cidades urbanas como as que residem na Cidade Estrutural. Ademais, muitos estudos que envolvem o tema da percepção em pesquisas no campo educativo "não dão conta de subsidiar uma discussão mais aprofundada sobre o que deveriam ser suas preocupações centrais, a saber: a natureza e as formas de relação do ser humano com as realidades imediatas, onde se inserem a coletividade e o lugar habitado" (MARIN, 2008, p.204).

Nesse processo investigativo, vários estudos têm proposto métodos de investigação no contexto da educação, utilizando fotografias para desvelar elementos relativos à percepção ambiental de diferentes sujeitos acerca de questões socioambientais vinculadas aos lugares onde vivem.

Nesse sentido, assumimos as seguintes questões para o delineamento da pesquisa:

-Com as crianças da cidade estrutural percebem o seu lugar de moradia?

-O que é revelado em termos das questões socioambientais a partir das fotografias realizadas pelas crianças de periferias das cidades ao transitarem pelas ruas dos lugares onde vivem? 
-Como as fotografias elaboradas pelas crianças da Cidade Estrutural interagem com as questões socioambientais locais discutidas na prática educativa? 


\section{OBJETIVO}

O objetivo do trabalho é revelar aspectos relacionados às imagens mentais que as crianças residentes na Cidade Estrutural têm sobre questões socioambientais vinculadas ao lugar onde moram a partir de fotografias.

Os objetivos específicos são:

- Identificar os aspectos socioambientais revelados a partir de fotografias realizadas pelas crianças sobre as cidades.

- Interpretar as imagens fotográficas realizadas pelas crianças sobre a cidade onde vivem; 


\section{ASPECTOS LEGAIS E DE FORMAÇÃO DE SUJEITOS ECOLÓGICOS NA EDUCAÇÃO AMBIENTAL EM CONSONÂNCIA COM OS PROCESSOS PERCEPTIVOS DE QUESTÕES SOCIOAMBIENTAIS NAS CIDADES PARA GARANTIA DOS DIREITOS DAS CRIANÇAS E ADOLESCENTES}

Vários esforços tem sido empreendidos para a garantia e defesa do direito da criança e do adolescente com a criação de normatizações, planos de ações e programas com esse foco em diferentes campos.

Nesse ensejo, o Estatuto da Criança e do Adolescente (ECA), Lei federal $n^{\circ}$ 8069/1990 regulamenta o artigo 227 da Constituição Federal e reitera a perspectiva trazida na Convenção Internacional Dos Direitos da Criança e do Adolescente (1989). Trata-se de uma normatização que institui a doutrina da proteção integral como a base para busca da garantia de direitos para todas as crianças e adolescentes. Tal doutrina indica destaca a necessidade de se garantir a sobrevivência, a integridade e o desenvolvimento físico, mental, moral, espiritual e social de crianças e adolescentes. Também sinaliza que as mesmas devem ser respeitadas na sua condição peculiar de sujeitos em desenvolvimento, tendo prioridade na efetivação dos direitos referentes à vida, à saúde, à alimentação, à educação, ao esporte, ao lazer, à profissionalização, à cultura, à dignidade, ao respeito, à liberdade e à convivência familiar e comunitária (FEDERAL, 2010).

No que diz respeito à garantir direitos nas periferias dos centros urbanos destacamos o Estatuto das Cidades (Lei federal $n^{\circ} 10257$, de 2001) que, dentre as diretrizes gerais, propõe a gestão urbana pautando-se pela participação, cooperação entre governos e garantia do direito às cidades sustentáveis. Tais diretrizes são propostas para se concretizarem a medida que informações sobre a cidade são disponibiizadas e os planejamentos e processos decisórios considerem o pensamento e experiências dos que vivem a cidade.

Tais normas podem ser vistas de forma complementar, pois podem contribuir para o amparo legal no estabelecimento de sistemas de governança local na 
gestão urbana que articulem programas e projetos e assim, garantam às crianças aspectos como:

- Oportunidade de influenciar decisões sobre sua cidade,

- Expressar sua opinião sobre a cidade que quer,

- Participar na família, na comunidade e na vida social,

- Receber serviços básicos de cuidados para a saúde, educação e abrigo,

- Beber água potável e ter acesso apropriado a saneamento,

- Estar protegido de exploração, violência e abuso,

- Andar com segurança pela cidade sozinho,

- Encontrar amigos,

- Ter áreas verdes para plantas e animais,

- Viver em um local na poluído,

- Participar em eventos culturais e sociais,

- Ter acesso a todos os serviços oferecidos independentemente de origem étnica, religião, classe, gênero ou deficiência (Buding child Friendly Cities: A framework for action, 2004; Bulding blocks for developing Child Friendly City ,X (tradução do proponente)

Ou seja, reiterar a necessidade de se implementar programas e projetos que garantam os direitos fundamentais das crianças tanto no que diz respeito à prestação serviços básicos para melhoria da qualidade de vida, garantia de infraestrutura e também a convivência familiar e comunitária.

Considerando que o direito à educação só se concretiza na perspectiva da busca dos demais direitos fundamentais ( ARROYO,2005) é fundamental que as práticas educativas ambientais contribuam para discussão, formulação, implementação e execução de ações de governança local na gestão urbana articulando todas as orientações legais como o Estatuto das Cidades e o ECA à formação de sujeitos ecológicos. Ou seja uma atuação que assuma a complexidade dos fenômenos e caminhem além de gerar comportamentos em prol da garantia de direitos, pois está em consonância com a reflexão de como 
as pessoas pensam o ambiente, e o desenvolvimento de capacidades e sensibilidades para compreender as questões socioambientais e assim, assumir o compromisso com as tomadas de decisões em favor do convívio solidários dos sujeitos.

Assim, o trabalho no campo da Educação assume uma posição baseada na totalidade complexa, o conjunto. A complexidade pode ser entendida como tecida na rede de acontecimentos, ações, interações, articulações, acasos, determinações que constituem nosso mundo ( MORIN, 2007).

Contrapõe, assim, à abordagem que foca em partes e não se integra ao todo que se pauta pelo cientificismo cartesiano. Traduz uma compreenssão-ação sobre o mundo crítica do paradigma dominante que historicamente se constituiu hegemônico na sociedade moderna e contribuiu para a constituição da sociedade capitalista.

A organização da sociedade capitalista contribuiu para o estabelecimento de problemas relacionados ao individualismo, à competição, à desigualdade, à injustiça socioambeintal, marginalização, desemprego e pobreza. Tais problemas são sinais de uma crise socioambiental, de um modelo de sociedade capitalista e seus paradigmas. Uma crise civilizatória, marcada pela perda da afetividade, do amor, da capacidade de se relacionar do um com o outro (social), do um com o mundo (ambiental). ( GUIMARÃES, 2004; LEFF, 2007)

No contexto brasileiro, a crise ambiental é marcada por assimetrias e injustiças nesse processo de organização social e na trajetória de mobilização no âmbito da educação ambiental, dentre as diferentes correntes, a perspectiva crítica reitera a necessidade de se assumir um compromisso social com foco no enfrentamento das desigualdades, que se revelam em várias manifestações sociais, seja em questões étnicas e de gênero, seja no acesso a serviços públicos, na ocupação de postos de trabalho e também na vinculação com a pobreza. (LAYRARGUES, 2009).

A crise paradigmática, civilizatória e socioambiental, anunciada desde a década de 60 abre caminhos para um novo paradigma que tem em suas bases uma preocupação ética-política educativa dos seres humanos na qual a 
educação, que não é neutra, é provocada a assumir um projeto libertador e crítico em que a visão sobre os sujeitos, a nossa forma de existir, de estar com os outros se coloca na base da reflexão e do fazer pedagógico com foco na intervenção em prol de processos de emancipação, transformação das desigualdades sociais e garantia de direitos.

Nessa perspectiva a Educação Ambiental incide no campo educativo retomando o foco em dimensões singulares da experiência humana sob uma nova epistemologia de um saber ambiental.

O saber ambiental [...] é a confluência de processos físicos, biológicos, e simbólicos reconduzidos pela intervenção do homem- da economia, da ciência, e da tecnologia- para uma nova ordem geofísica, da vida, e da cultura.( LEFF, 2007, p.9)

A Educação Ambiental subsidia a compreensão das relações sociedadenatureza a partir do saber ambiental baseado em um novo paradigma de intervenção-compreensão sobre as questões socioambientais com múltiplas dimensões (geográficas, históricas, biológicas, sociais e subjetivas contextualizadas e históricas).

Nessa perspectiva, retomando a questão da garantia dos direitos da criança no contexto da Educação, as crianças, podem ser compreendidas, enquanto sujeitos ecológicos em formação, ou seja, portadores de um ideal ecológico, que sintetiza "as virtudes de um experiência ecologicamente orientada, que busca responder os dilemas sociais, éticos e estéticos configurados pela crise socioambiental, apontando para a possibilidade de um mundo socialmente justo e ambientalmente sustentável" (CARVALHO, 2008, p. 26).

Sujeitos que trazem, na sua experiência de vida individual e comunitária, a participação em processos de aprendizagem a medida que vão se desenvolvendo, vivenciando o ambiente e sendo estimulados. As crianças, assim, vão agindo mais do que do respondendo à regras de comportamento e padrões de conduta instituem modos de ser e de compreender, de posicionar 
diante de outros e de si mesmos, enfrentando desafios cotidianos e estabelecendo valores ecológicos para vida.

Tais valores constituem como predisposições para que os sujeitos possam se comportar de uma maneira específica, tendo como referência a percepção ligada às sensibilidades éticas e estéticas relacionada à vida no âmbito individual e coletivo.(PATO, 2004; CARVALHO,2008).

Nessa perspectiva, a Educação Ambiental sintetiza o esforço para que haja a inclusão, nos temas formadores e nos processos de aprendizagem, da problematização das questões socioambientais e das bases dos conflitos sociais que afetam os sujeitos, bem como a provocação para uma ação transformadora na perspectiva da garantia de direitos das crianças.

Como aponta Carvalho(2008) a formação se faz na relação indivíduosociedade, ao passo que os sujeitos se fazem na sua relação com o mundo e se reponsabiliza com as diferentes dimensões da ação humana. Assim, tendo a complexidade como parâmetro, recusa a crença individualista de um mudança social advinda da mudança das partes, e também a sua contrapartida que destaca a necessidade de mudança em um sistema social genérico para que haja transformações da vida dos sujeitos. Nesse caso, há uma valorização do cuidado consigo, com os outros e com o ambiente sem dicotomizar e estabelecer hierarquias entre ambas esferas na construção da realidade pelos sujeitos.

Nesse caso, destaca a necessidade de não simplesmente transmitir conhecimentos para uma compreensão dos problemas, mas refletir sobre a experiência cotidiana e participar de forma a contribuir para ampliar a compreensão e intervenção na realidade. Também reforça que não seja privilegiado apenas aspectos cognitivos do processo pedagógico, como também aspectos afetivos, emocionais numa perspectiva complexa. (CARVALHO 2008; GUIMARÃES,2003)

A Educação Ambiental assim, é apresentada "como uma mediação importante na construção social de uma prática político-pedagógica portadora de nova sensibilidade e postura ética, sintonizada com um projeto de cidadania ampliada pela dimensão ambiental" (CARVALHO, 2008, p. 26). 
Valoriza se então a compreensão da rede de relações da e na Natureza fundamentada na ética e cidadania em que há a tomada de consciência e assim, o reconhecimento que para o equilíbrio ecológico é necessária a percepção do papel que o ser humano no ecossistema planetário preocupado com o sentido mais profundo do que fazemos com nossa existência.(GADOTTI, 2000).

Podemos considerar que a experiência da existência envolve pensar, sentir e tornar-se consciente. Uma existência que, dentre as possibilidades possíveis, envolve a reflexão sobre quem somos, o que sentimos e queremos indissociada de uma ação no mundo (FREIRE 1967,1988).

Assim, a Educação Ambiental reitera a necessidade de uma percepção de mundo, individual e coletiva e também historicamente situada, que promova a compreensão complexa, crítica e reflexiva e o engajamento socioambiental e uma intervenção social. Ao passo que os sujeitos, individuais e coletivos, são convidados a refletirem sobre aspectos da interrelação das pessoas em seu ambiente, mediante estímulos de uma prática pedagógica, podem pensar atitudes para conquista ou restauração da qualidade de vida e da garantia de direitos e, de acordo com as possibilidades, ressignificarem as imagens mentais elaboradas sobre o ambiente, chegando a mudar suas formas de ser, estar e agir no mundo.

Kuhnen (2011), destacando a trajetória reflexiva no campo da percepção, considera que os aspectos socioculturais (significados, valores, contextos) e históricos (contexto político, economia, dentre outros), além das características físicas e dos aspectos psicossociais (cognição, afeto, preferências, dentre outros) estão envolvidos na percepção ambiental.

O ambiente das cidades não são algo em si mesmos, mas objetos de percepção de seus habitantes, que elaboram imagens mentais sobre elas ( $\mathrm{LYNCH}, 1980)$. Assim, ao interpretar a realidade cada sujeito pode ter diferentes percepções em termos de satisfação diária, de acesso e garantia de direitos de acordo com contexto de quem observa. 
Ademais, uma vez que estamos em constante interação com o ambiente, estamos envolvidos por ele e a forma de acesso, bem como a própria interação, está por ele influenciada num movimento em que o sujeito se posiciona no mundo de forma ativa, seletiva, construtora de sentidos, de realidades e criadora de imagens mentais e sistemas de ação ( LURIA, 1979; DEL RIO, 1999; KUHNEN, 2011).

Nesse caso, assumimos que as imagens mentais das cidades têm uma base social que, como Lynch (1980) coloca, serve de símbolos e memórias sociais que contribuem para comunicação entre indivíduos e grupos. Assumimos também que os constituintes físicos das cidades fazem parte do mundo social historicamente constituído e que, de alguma forma, assumem os aspectos biológicos, psicológicos, sociais, culturais e históricos próprios das pessoas que ali os experienciam em contextos específicos. Isso acontece pois as imagens mentais formuladas são influenciadas pelo processo de percepção.

Para Del Rio (1999), a percepção, enquanto um processo mental de interação do indivíduo com o meio ambiente, se dá em função de mecanismos perceptivos, principalmente cognitivos, que envolvem a orientação dos estímulos externos, captados por meio dos cinco sentidos. De acordo com Del Rio e Oliveira (1999,p. X) a cognição é considerada como "processo mental mediante o qual, a partir do interesse e necessidade estruturamos e organizamos nossa interface com a realidade e o mundo, selecionando as informações percebidas, armazenando as e conferindo-lhes significado".

A cognição também é entendida como "processo por meio do qual as pessoas criam imagens mentais" (ARAGONÉZ, 1991; ITTELSON, 1978 apud KUHNEN, 2011, p. 256). Sendo que as imagens mentais podem ser compreendidas como referencias sobre a organização do pensamento.

De acordo com Luria (1979), por meio das sensações, as informações relativas aos fenômenos do mundo exterior chegam ao cérebro da pessoa, colocando-a em contato com este mundo e permitindo que ela o compreenda. O autor destaca que a sensação tem um caráter ativo e seletivo, integrada a um movimento. Por exemplo: a percepção visual de algo se realiza com a 
participação ativa do movimento dos olhos, que pode assumir diferentes reações motoras (seja abrindo bem os olhos ou fazendo um leve movimento), dependendo da importância das influências do mundo exterior.

Entretanto, é no trabalho conjunto dos sentidos, "na síntese de sensações isoladas e nos complexos sistemas de conjuntos" (LURIA, 1979, p. 38) que é oportunizada a percepção. De acordo com o autor, esse processo requer que se discriminem do conjunto de indícios atuantes (cor, forma, propriedades táteis, peso, sabor, etc.) os indícios básicos determinantes, com a abstração simultânea de indícios inexistentes.

Para haver a identificação de um objeto, ocorre uma confrontação dos indícios com os conhecimentos anteriores do objeto. Dessa forma, "a percepção plena de um objeto surge com resultado de um complexo trabalho de análise e síntese, que ressalta os indícios essenciais e inibe os indícios secundários, combinando detalhes percebidos num todo apreendido" (LURIA, 1979, p.40), Nesse processo, o objeto perceptível é categorizado, separando-se de outros objetos semelhantes por meio de formulações que podem assumir um caráter variável, como um prato girando que é visto, a princípio, num formato oval e depois parado, assumindo um caráter circular.

A percepção a partir da experiência cotidiana passa por um processo de desenvolvimento, no qual ocorre uma reorganização qualitativa cujo resultado é a substituição de formas elementares imediatas por uma complexa atividade perceptiva, constituída tanto pelo conhecimento de um objeto quanto pela análise das particularidades essenciais deste, que é feita com a participação imediata do discurso. As percepções dos sujeitos são formadas em determinada cultura e, por isso, os indícios da realidade percebida precisam ser contextualizados no âmbito social e histórico (LURIA, 1979).

No contexto infantil, quando diferentes significantes passam a se diferenciar por meio de imagens, ocorre o processo de construção de significados e percepções sobre o ambiente da cidade. Este ambiente pode ser assumido como lugar que moram, brincam e transitam, coberto de significação e reconhecido a partir do valor atribuído à vivência neste lugar e aos sentimentos 
relacionados a ele. Nesse caso, outros componentes psicossociais, como afeto e preferências, também contribuem, possibilitando a decodificação das informações proporcionadas e a transformação do que é visto em significados No que diz respeito à construção do senso das cidades organiza os espaços e as relações socioambientais, a criança vão ampliando a noção a partir convivência familiar e dos espaços de moradia (KUHNEN, 2011; CAVALCANTE; NOBREGA, 2011; HIGUCHI ,2008; HIGUCHI e KUHNEN, 2008).

Reforçando o destaque anteriormente dado à diferentes dimensões que influencia na elaborações do pensamento sobre o ambiente, Del Rio (1999) reitera a visão de que a percepção ambiental não pode ser reduzida à cognição, um aspecto psicossocial, pois a nossa mente atua na organização e na representação de esquemas perceptivos e de imagens mentais, com outros atributos específicos.

De acordo com Kuhnen (2011), as características de um lugar são captadas pela percepção em função de particularidades de determinadas operações fisiológicas humanas, assim como das condições ambientais e da configuração do espaço. Tais elementos contribuem para o estabelecimento de estruturas de referência sobre as cidades, um esquema mental constituído de referências de ruas e lugares e de fenômenos que as interpelam.

A organização do campo visual é influenciada pelas características do mundo físico, facilitando ou dificultando a organização das informações. De acordo com Lynch $(1959,1999)$, um ambiente com grande quantidade de estímulos visíveis pode provocar ou inibir certas atividades.

Assim, podemos afirmar que as imagens mentais sobre as cidades envolvem de forma inter-relacionada, tanto características externas - como a conformação da cidade ou situações que ocorrem cotidianamente - quanto aspectos da produção do observador e são, ao mesmo tempo, produtos e produtoras de relações sociais. A partir da experiência cotidiana, as imagens elaboradas são progressivamente internalizadas, constituindo extratos cognitivos, quadros mentais generalizados do mundo exterior que podem servir como referências organizadoras de atividades, de crenças ou de conhecimentos 
que servem para formulação dos significados. A partir das imagens, as informações são interpretadas, influenciando na forma como a pessoa vive a cidade (LYNCH, 1980; KUHNEN, 2011).

Cabe destacar que o processo de construção de significados é dinâmico e contínuo, ao passo que as concepções são repetidas e modificadas. As crianças, dessa forma, a partir do seu desenvolvimento cognitivo, das experiências de vida e estímulos recebidos pelo ambiente criam e reproduzem significados e práticas próprias de grupos, transformando-os continuamente, se distinguindo como seres autônomos e transformadores em sua essência (HIGUCHI e KUHNEN, 2008).

Tendo esses elementos que envolvem o processo perceptivo como norteadores do trabalho educativo, pode -se construir ou fortalecer as bases de um trabalho que inspire para o engajamento dos sujeitos, a fim de encontrar soluções possíveis ou formas de enfrentamento dos desafios relativos às questões socioambientais, mobilizando sentimentos e reflexões, envolvendo a comunidade em suas propostas.

\section{O MÉTODO}


De acordo com Lüdke e André (1986), a pesquisa em educação precisa estar situada dentro da vida diária do educador, tornando-se um instrumento para o trabalho. Nesse caso, a partir da interrogação que é feita dos dados e dos fatos do cotidiano, tendo como referência a teoria acumulada sobre o assunto diante de um contexto sócio-histórico-cultural, o conhecimento é construido sobre o que está sendo pesquisado, numa intricada relação entre sujeito de pesquisa, pesquisador e objeto de estudo. Há uma procura na pesquisa educacional de se "captar essa realidade dinâmica e complexa do seu objeto de estudo, em sua realização histórica" (LÜDKE; ANDRÉ, 1886, p.5), e assim, subsidiar a prática educativa. Dessa forma, valoriza-se a compreensão de que a realidade se faz na síntese entre sujeito e objeto e na aplicação reflexiva e prática dos referenciais teórico-metodológicos oferecem elementos para construção do conhecimento.

Tal abordagem esta em consonância com a proposta de um conhecimento que se construa a partir de uma atuação no mundo que dê destaque para a " experiência de consciência em que 'tudo que é informado pelos sentidos é mudado em uma experiência de consciência de se perceber a realidade.

Assim, vai ao encontro das premissas da Educação ambiental subsidiando a compreensão complexa do real e uma prática educativa que forneça elementos para construção da compreensão dos sujeitos e sua relação com o mundo sob bases pautadas na solidariedade e no equilíbrio entre as relações (Guimaraes, 2004, Loureiro, 2004). Assim, esta ligada a um projeto transformador da sociedade alimentando um discurso complexo do existir e estar ambiente e a vida.

Nesse caso, o educativo, o político e o ambiental são colocados indissociáveis no contexto da pesquisa, em que a compreensão de um aspecto se faz na sua relação com o conjunto tendo a pesquisa acadêmica um papel de destaque na compreensão-ação dos sujeitos na sua interação com as questões que os envolvem. 
Em consonância com esse olhar de destaque para o espaço educativo enquanto espaço de pesquisa, Higuchi e Kuhnen (2008) e Kuhnen e Higuchi (2009) sugerem o engajamento dos educadores enquanto pesquisadores na investigação de questões vinculadas às dimensões psicossociais dos comportamentos associadas ao contexto físico. Nesse caso, o educadorpesquisador desenvolve uma pesquisa participante e tem o papel de conduzir e mediar as atividades propostas com as crianças na escola e coletar, observar registrar e analisar os dados pertinentes à pesquisa, fazendo interagir esse processo investigativo com os planos de aulas.

Dessa forma, para se oportunizar a elucidação das questões socioambientais que se revelam a partir de como as crianças pensam e vivenciam o ambiente, cabe ao educador criar condições para que tal educação surja, considerando os limites da sua ação pedagógica, procurando educar-se educando, aprendendo e ensinando sem renunciar ao risco de indicar um caminho mediante o diálogo entre ele e o educando (GADOTTI, 1981). Para isso pode usar métodos e técnicas de pesquisa aliada à prática educativa.

Uma das possibilidades que se apresentam é a realização de oficinas integrando atividades educativas às de pesquisas. Para tanto, o ensino da fotografia pode contribuir no desvelar das imagens mentais formadas pelos educandos acerca da sua vivência cotidiana, pois fotografar é um ato de se comunicar, de expressar o que se pensa e se sente.

A fotografia, a partir de seu caráter informativo e de expressão, pode representar um instrumento para se repensar a percepção de aspectos da realidade vivida cotidianamente e interpretada dentro de um contexto sóciohistórico por cada sujeito.

Além disso, a partir do interesse do aluno é possível ocorrer um processo de aprendizagem. Assim, pelo desejo de aprender a fotografar e pela possibilidade de revelar o seu modo de vida, cria-se um ambiente de abertura ao diálogo e ao estimulo para o trabalho educativo ambiental.

Com o ensino da fotografia e com o compartilhamento do conhecimento gerado a partir dessa experiência é oportunizado um trabalho na formação de 
cidadãos conscientes, críticos e responsáveis que problematizam a realidade das cidades e participam na mobilização comunitária para construção da garantia de direitos tão necessária, como estudos sociodemográficos apontam.

A fotografia, enquanto expressão artística, permite ao ser humano articular conhecimento, historicidade, linguagem, afeto e intuição, fazendo interagir diferentes dimensões dos sujeitos. Nessa perspectiva, constitui-se como um importante instrumento para suscitar a intervenção na realidade de forma a buscar superações de processos sócio-históricos.

No processo de elaboração das imagens fotográficas haveria uma primeira realidade (KOSSOY, 2002, 2009), que envolve o fenômeno no momento em que ocorreu o registro, interrompido e isolado na bidimensão da superfície sensível. A realidade no contexto da produção das imagens (primeira realidade), "os componentes tridimensionais das paisagens, dos vestígios da ação do homem, que serviram de quadro para um certo fotógrafo efetuasse, através da câmera, o devido registro sobre o plano bidimensional do material sensível" (KOSSOY, 2009, p. 36) em um preciso espaço e tempo é que torna o visível fotográfico.

A partir do registro do tema visível pelo fotógrafo, com uso de um equipamento específico, passa haver uma segunda realidade, interpretada a partir do fragmento congelado da cena, materializado iconograficamente.

Dessa forma, como resultante da ação humana inter-relacionada com o tema e o equipamento que possibilita o respectivo registro, tem-se a fotografia, que assume uma realidade própria, a segunda realidade. No entanto, ela sempre está condicionada à primeira interpretação do fotógrafo, ainda que seus conteúdos sempre sejam interpretados de formas diversas: com implicações sentimentais ou não, variando de acordo com o vínculo e conhecimento do assunto registrado.

De acordo com Kossoy (2002, 2009), a fotografia é uma evidência documental de algo que ocorreu na realidade concreta e que não se constitui como registro fidedigno da realidade ou da verdade absoluta. Trata-se de uma verdade iconográfica, produto de um processo de criação-construção ambíguo 
por excelência a partir da elaboração técnica, cultural e estética do autor da representação e de outros coautores que, de alguma forma, interferiram no processo.

Como Kossoy $(2002,2009)$ aponta, as imagens nos mostram um fragmento selecionado da aparência das coisas, das pessoas, das formas, dos fatos tal como foram (estética/ideologicamente) congelados num dado momento de sua existência/ocorrência por meio do uso de um equipamento específico.

Ainda que no processo de elaboração das imagens o domínio da técnica e as características dos equipamentos (sofisticados ou não) devam ser considerados, tal como Kossoy (2002) destaca, a bagagem cultural, a sensibilidade e a criatividade são elementos fundamentais na produção, bem como o tema. Para Kossoy (1941), não há um simples registro mecânico de aspectos da realidade, há uma elaboração estética e criativa em que aspectos psíquicos relacionados à dimensão criadora dos sujeitos estão na base dessa forma de expressão.

No ato fotográfico o vínculo afetivo com o objeto fotografado, a preocupação com os elementos de comunicação visual ou a inserção da fotografia com a expressão de sua vida e da memória podem se revelar conscientes ou não, mas, como Kossoy (2009) coloca, a organização do campo visual se faz na construção das imagens a partir da elaboração estética.

A fotografia surge a partir do desejo em realizar tal feito por parte do fotógrafo e o respectivo registro visual documenta a atividade criativa do autor, que se utiliza dos recursos técnicos dos equipamentos para registrar um tema. A composição da imagem pode ser elaborada utilizando efeitos ópticos e químicos para realizar abstração, montagem e modificação e alteração visual dos elementos ou mesmo o próprio enquadramento pode ser explorado pelo autor, destacando detalhes que compõem o assunto na produção de efeitos.

As fotografias são, "a um só tempo, reveladoras de informações e detonadoras de emoções" (KOSSOY, 2009, p. 28). Algumas imagens podem não se destacar dentre várias outras, ou incólumes despertarem espontaneamente diferentes emoções corporalmente identificadas, como mãos suadas, agitação, 
choro, riso, melancolia que, de toda forma, fornecem um vasto cenário de informações que fazem menção ao seu referente (KOSSOY, 2009).

Para Higuchi e Kuhnen (2008), ao perceberem a imagem fotográfica exposta de um mundo, as imagens mentais se aglutinam numa veia de significações complexas. Nesse caso, além da forma há também a possibilidade de se realizar uma análise perceptiva do que é visto. Segundo as autoras, ao vermos as imagens um ideário se abre, expondo o que dificilmente seria apresentado de outra forma. O que é percebido assume a conformação de uma imagem mental repleta de sentidos e permeada de novas significações.

A fotografia permite o desvelamento dos sistemas de significação do que a produz, que acabam sendo manifestados como um sistema coletivo de uma dada sociedade. Elas revelam características de certas percepções de mundo, estabelecendo uma relação comunicacional em que um discurso é narrado.

Ao captar uma imagem da cidade a pessoa elege, destaca e seleciona, dentre a multiplicidade de fenômenos que envolvem a vida, o que considera fotografável, um fragmento do que é visível e, consequentemente, contextualizado. Da mesma forma, ao ler uma fotografia o receptor, também a partir dos signos presentes na imagem, elabora associações e a interpreta.

Nesse caso, para que as narrativas sejam compreendidas (HIGUCHI; KUHNEN, 2008), elas precisam ser apreendidas a partir da consideração do contexto em que são pronunciadas mediante a observação e o registro das interações.

Silva (2006) destaca as contribuições metodológicas da proposta de Luis Gonzaga Motta, com a narratologia do vivido, em que o narrador do vivido é um revelador de imagens latentes que busca decifrar enigmas e sombras da produção simbólica por meio das vozes envolvidas na trama fotográfica a ser construída.

As contribuições dos autores acima citados para a leitura e análise das imagens podem ser integradas à proposta de Kossoy (2009), que sugere uma análise técnico-iconográfica para recuperação das informações que envolvem o documento fotográfico com a reconstrução do processo que gerou o artefato, a 
explicitação dos seus elementos constitutivos tanto histórico-políticos quanto socioeconômicos e suas coordenadas de situação, a determinação dos elementos icônicos que compõem o registro visual e o conteúdo da representação.

Nesse caso, tendo como referência as realidades fotográficas que envolvem o processo de elaboração das fotos, Kossoy (2009) propõe que seja considerada uma série de elementos que contribuem para uma interpretação do documento e o consequente melhor entendimento sobre a vida representada que, inclusive, pode não estar exposta no visível fotográfico.

No âmbito da descrição propõe-se que seja descrito e constatado o que é possível ver, os elementos da representação fotográfica que abarcaram a composição da imagem envolvendo o autor, o tema tratado e a técnica. Para a interpretação e apreensão do significado do conteúdo é necessário, segundo o autor, desvendar o contexto que envolveu o referente (no caso, a primeira realidade), tendo como parâmetro o assunto da forma como foi retratado (a segunda realidade). De acordo com Kossoy (2002, 2009), a interpretação da imagem prescinde de uma compreensão dos usos, da veiculação de idéias e da consequente formação e manipulação da opinião de quem a vê, uma vez que a estética de representação das imagens pode servir para diferentes construções de discurso. 


\section{METODOLOGIA}

\subsection{Contexto}

A pesquisa foi realizada na Cidade Estrutural, que surgiu na década de 60 após a chegada pessoas para trabalhar na coleta de recicláveis no "lixão", local deposito de lixo do DF.

A Cidade Estrutural está localizada próximo ao Plano Piloto do DF, entre as vias DF-095( ao sul) e DF-097 ( ao norte), limítrofe ao Parque Nacional de Brasília e o Córrego da cabeceira do Valo (Integrante da Área de relevante interesse ecológico- Arie Cabeceira do Valo) conforme é possível ver na figura abaixo (Fig. 2).

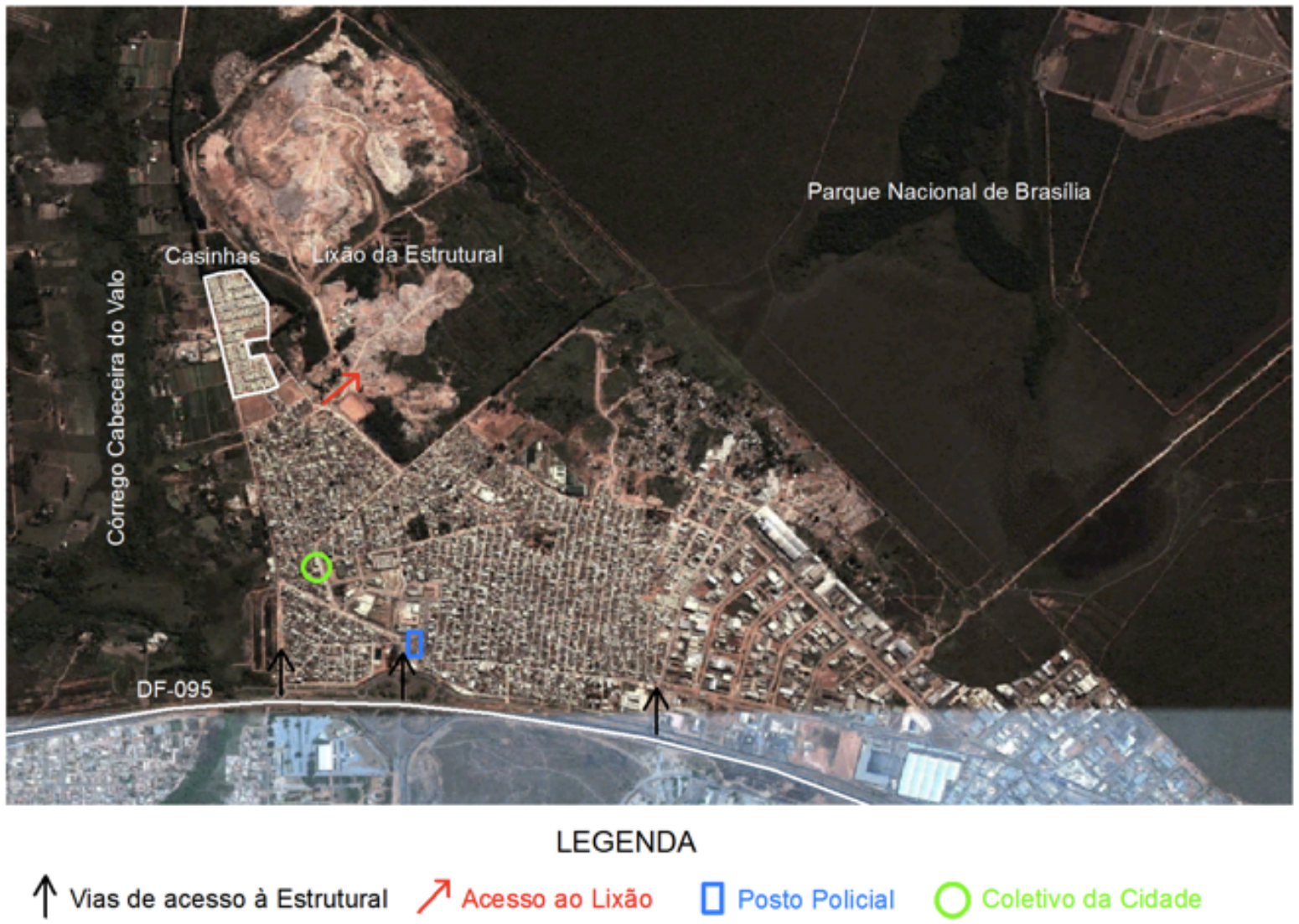

Ilustracação 2- GOOGLE.Imagem de satélite, 2002 
A ocupação da área que hoje abrange a Cidade Estrutural se fez sobretudo na década de 90 , quando aumentou o número de famílias na localidade, indo de encontro a sucessivas tentativas empregadas por parte do Governo do Distrito Federal para que a ocupação não crescesse. Em 1993, foram cadastradas 393 famílias, e atualmente estima se que tenham 6.254 famílias. ( DISTRITO FEDERAL , 2004, 2011)

Ao longo dos anos as pessoas que lá residiram enfrentaram problemas característicos de assentamentos tidos como "invasão": infraestrutura de saneamento e abastecimento de água precária, dificuldades de acesso à equipamentos públicos como escolas e postos de saúde, ruas sem asfalto e estreitas entre outros.

Apenas em 2002, iniciou processo de regularização com a Lei Complementar Distrital n530/02 desencadeada por articulações políticas e mobilização da comunidade por moradia. Nesses anos, como parte da iniciativa para fixar a população local e para implantar um projeto urbanístico na localidade foram decretadas leis (Lei complementar $n^{\circ} 715 / 2006$ ) e delineados programas governamentais como Programa Brasília Sustentável (contrato 7326). E assim, iniciou se a construção de equipamentos públicos como escolas, postos policiais, postos de saúde.

Ao longo desses anos, associações civis também empreenderam programas e projetos em vários campos de atuação. DISTRITO FEDERAL , 2004, 2011) A presente pesquisa se realizou em parceria com o Coletivo da Cidade. O Coletivo da Cidade, é uma entidade não governamental que, desde 2011, realiza atendimento com crianças e adolescentes no contraturno escolar na Cidade Estrutural (Quadra 03, Conjunto 03, Lote 47, Setor Oeste). Oferece atividades de reforço escolar e artístico-pedagógicas, como aulas de idiomas, violão, xadrez, break, oficina de direitos, bem como atendimento psicossocial às crianças e seus familiares. Atua articuladamente com a rede de controle, proteção e defesa dos direitos das crianças e adolescentes. A equipe de trabalho é composta por assistentes sociais, psicólogos e educadores, dentre outros. 
As crianças atendidas, com idade entre 10 e 14 anos, são encaminhadas pelo Centro de Referência de Assistência Social (CRAS) vinculado à Secretaria de Desenvolvimento Social do Governo do Distrito Federal após seleção de acordo com perfil socioeconômico familiar e disponibilidade de atendimento.

\subsection{Sujeitos}

Participaram da pesquisa cinco crianças atendidas pela entidade. Para fins da pesquisa cada uma delas esta identificada com um "nome artístico" fictício proposto por cada um dos participantes. São eles: Yohaninha, Cassi, Pedro, Fran, Bia, Gênio e Jaque.

Destas, quatro crianças eram do sexo feminino e uma do sexo masculino, todas com idade entre 9 (nove) e 12(doze) anos. A escolha dessa faixa etária foi motivada pelo estudo de Huguchi (2008) que aponta que nessa faixa etária as crianças estão iniciando a construção de abstrações sobre as dinâmicas que acontecem em seus espaços.

Todas residem na mesma região da Cidade Estrutural, no Setor Oeste. De acordo com os dados obtidos por meio da ficha de cadastro dos participantes e das conversas com eles as moradias tem construções de alvenaria e todos são os proprietários com acesso à água encanada. Apenas a casa de um dos participantes ainda não possui acesso ao esgotamento sanitário.

Para seleção dos participantes foi consultado o número total de interessados dentre os atendidos pela entidade no período da tarde e depois realizado o sorteio de 12 nomes. O número de sujeitos participantes da pesquisa foi definido levando em consideração o número mais adequado ao método usado, de 4 a 8 crianças, bem como as possíveis desistências. O Oficina iniciou com a participação de 7 crianças porém 2 deixaram de ser atendidas pela OnG e de participar da Oficina. 


\subsection{Estratégia: Oficina Imagens da Cidade, fotografando o ambiente}

Foi realizada uma oficina educativa com título Imagens da Cidade, Fotografando o ambiente.

A oficina foi iniciada no dia 25 de abril de 2012 , tendo como proposta a realização de três encontros. Diante do envolvimento e interesses das crianças, disponibilidade da pesquisadora e necessidade de mais tempo para a realização de atividades para finalização do trabalho, tais encontros foram estendidos, sendo a oficina concluída no dia 13 de junho, com a realização de oito encontros, sendo três deles realizados fora do Coletivo da Cidade. A proposta é que se dê continuidade à oficina em outro momento e que ela também seja estendida aos demais interessados que não puderam participar nessa ocasião.

Teve como pilares os elementos apresentados no capítulo 5 em que foi destacada a pesquisa situada na vida diária do educador atentendo aos limites e potencialidades do espaço educativo enquanto espaço de pesquisa (LUDKE e André,1986; HIGUCHI e KUHNEM,2009; KUHNEN e HIGUCHI,2009)

O planejamento da oficina foi realizado considerando que, em cada dia de atividade da oficina, tivesse 4 etapas: integração, sensibilização, criação e fechamento, tendo como referência os pilares propostos por Kuhnen e Higuchi (2008). Segue abaixo o detalhamento de cada etapa.

A integração consistiu em realização de jogos, brincadeiras e conversas, inclusive contando com a sugestão das próprias crianças. Elas foram realizadas de forma a possibilitar o desenvolvimento de empatia, solidariedade entre os participantes e a abertura para a realização da pesquisa (KUHNEN; HIGUCHI, 2008). No planejamento foram sugeridas algumas atividades, no entanto, a proposta inicial era a de que a pesquisadora acolhesse os participantes, perguntando sobre como havia sido o dia e qual atividade eles gostariam de fazer naquele momento, de acordo com a disponibilidade do tempo.

A sensibilização contemplou a preparação para a atividade, que aconteceu com a explicação do que seria feito, criando um espaço motivador. Nela foi explicada a proposta do encontro, de forma simples e sintética. 
Atividades que incentivavam a concentração foram desenvolvidas de acordo com a necessidade percebida pela pesquisadora-educadora.

Já a criação envolveu a execução propriamente dita da atividade que foi considerada na pesquisa. Maior tempo foi destinado para a realização de tal etapa. Destacamos que, nos encontros, a etapa de criação previu a utilização das técnicas fotografando o ambiente (HIGUCHI; KUHNEN, 2008) e roda de diálogos adaptadas ao contexto.

O fechamento implicou na realização de uma breve avaliação do dia, realizada de forma interativa e dinâmica.

A descrição da Oficina será apresentada no item 6.6 e os resultados serão apresentados no capítulo 7 .

\title{
6.4 Instrumentos
}

Como Higuchi e Kuhnen (2008,p. 182 ) apontam, ao proporem pesquisas no contexto educativo:

\begin{abstract}
as técnicas compreendidas são empregadas durante o fazer da própria atividade educativa como um processo que não se encerra em si mesmo, mas retroalimenta novos conhecimentos que surgem durante a ação desenvolvida. Para as autoras nesse caso, há um processo investigativo contínuo, com a participação dos educandos e educadores que corrobora com o próprio ato de aprender.
\end{abstract}

Assim, integrando à estratégia escolhida para desenvolvimento da pesquisa foram realizado jogos, dinâmicas de grupo, roda de diálogos, passeios, bem como registros fotográficos por parte das crianças e consulta de material disponível sobre a Cidade Estrutural. Destaque especial faço ao uso dadaptado da técnica fotografando o ambiente (HIGUCHI \& KUHNEN, 2008)em uma atividade realizada durante passeio pela cidade. A partir do processo desencadeado da leitura das fotografias, oportunizado pelo uso dessa técnica foi possibilitado atingir aos objetivos do trabalho. 
Ademais, foram elaborados roteiros de atividades(Apendice E) e foi também realizado o diário de bordo. Os roteiros de atividades sofreram alterações em virtude das dificuldades de infraestrutura, motivação dos envolvidos e oportunidades advindas da prática cotidiana.

\subsection{Procedimentos}

A escolha da entidade foi motivada pela abertura e interesse desta na realização da oficina/pesquisa e do envolvimento da pesquisadora na concretização de oficinas pedagógicas junto às pessoas que estão responsáveis pelo trabalho em outras oportunidades.

Foi formalizada a autorização da entidade por meio da assinatura de um termo, cujo modelo encontra-se nos apêndices (APÊNDICE A).

Após o sorteio dos participantes, foi enviada, pela coordenação pedagógica do Coletivo da Cidade, conforme praticando pela entidade, por intermédio das crianças sorteadas, uma correspondência aos pais, cujo modelo também encontra-se nos apêndices (APÊNDICE B). No documento constava a apresentação do objetivo a pesquisa, sua contextualização no âmbito das atividades oferecidas pela entidade, os procedimentos e outros dados pertinentes, além da autorização dos pais. As autorizações dos pais foram entregues pelas crianças no primeiro dia de atividade.

As alterações nos procedimentos e nos dias dos encontros que se fizeram necessárias foram notificadas aos pais por meio de outras correspondências e contato por telefone.

Uma ficha de cadastro de cada criança foi elaborada a partir de dados fornecidos pela entidade, que são disponibilizadas pelos pais durante a inscrição, e pelas próprias crianças no decorrer da oficina (APÊNDICE C). Nela constam dados relativos ao local de residência do aluno, a fim de contextualizar espacialmente o lugar de residência dos sujeitos da pesquisa, dentre outros. Parte dos dados foram omitidos nesta pesquisa como, por exemplo, endereço completo e nome da criança para preservar os participantes. 
A entidade disponibilizou o espaço e fez o contato com os pais e a pesquisadora providenciou todo o material usado com recursos próprios. As atividades vinculadas à oficina aconteceram nos espaços, de acordo com a demanda da atividade e disponibilidade. Ao final de cada encontro, o roteiro elaborado para o próximo era revisto, considerando as informações do diário de bordo. No próximo capítulo será apresentada a trajetória da oficina, destacando elementos centrais dos roteiros (APÊNDICE D) .

Por meio do contato direto, através do trabalho de campo, os dados foram coletados e registrados no diário de bordo da pesquisadora, buscando registrar o observado nas situações em que foi possível às crianças manifestarem sua percepção da cidade e as reflexões ao longo da atividade de campo, bem como possibilitaram que a pesquisadora vivenciasse esta cidade ao andar pelas ruas.

\subsection{Trajetória percorrida na oficina imagens da cidade, fotografando o ambiente}

Segue abaixo a descrição da trajetória percorrida na oficina. Os dados foram colocados para contextualizar o leitor sobre todo o processo de construção da primeira realidade fotográfica, a análise encontra-se no capítulo 7 .

\subsubsection{Encontro 1}

Conforme apontado no roteiro (APÊNDICE D), iniciamos a oficina com a etapa de integração, realizando a atividade de elaboração de crachá (em que os participantes colocavam seu nome e um outro nome artístico), seguida de apresentação. O foco dessa atividade era permitir que cada uma das pessoas do grupo se apresentasse e gradativamente pudesse decorar o nome de todos, além de possibilitar que as próprias crianças pudessem escolher um nome a ser usado nesse trabalho. 
Dessa forma, Bia, Cassi, Yohaninha, Pedro, Gênio, Jaque e eu elaboramos nossos crachás. Optei por preparar o crachá com eles, a fim demonstrar praticamente que a oficina seria vivenciada por todos e para promover uma aproximação junto às crianças.

Durante o momento em que todos estavam se apresentando, em virtude das manifestações das crianças sobre o trabalho que fizeram, foi possível que eu colocasse alguns dos pilares que sustentavam toda a oficina: liberdade para expressar o ponto de vista, ainda que outros não concordassem, não procurar se constranger ou constranger o outro por errar ou fazer algum trabalho feio, mas sim se dedicar no que estivesse fazendo, respeitar o trabalho dos colegas.

Alguns se mostraram tímidos durante a apresentação, falando baixo, não se apresentando espontaneamente para falar o nome que escolheu.

Ainda no momento de integração, foi realizada uma atividade corporal chamada Olhar pela moldura, em que foi entregue a cada um dos participantes uma moldura feita de papelão de $10 \times 15 \mathrm{~cm}$ de tamanho que eles carregavam ao circularem pelo espaço. Quando eu falava "foto", eles tinham que olhar pela moldura da forma como eu instruía, por exemplo, inclinando a cabeça para o lado direito e para baixo e olhando.

Para a realização da atividade, saímos da sala que estávamos por esta não dispor de espaço suficiente. A Fran juntou-se ao grupo nesse momento, porque antes estava fazendo o dever de casa.

Ao final, perguntei para eles se tinham visto algo diferente e o que tinham visto. Aos poucos, foram se manifestando e, só após eu ir sugerindo elementos que eles poderiam ter visto, alguns confirmaram ou não.

A atividade contribuiu para abordar a reflexão sobre a primeira realidade fotográfica. Ao final, voltamos para a sala, seguindo, de acordo com o roteiro, com a etapa de sensibilização. Foi esclarecida a dinâmica da oficina e seu objetivo. Eles perguntaram sobre o porquê do passeio pela cidade ser dividido e por que ele aconteceria nas ruas perto de onde moram. A proposta inicial era que fossem definidas, conjuntamente, regras para a convivência no grupo, mas, 
como as crianças estavam reticentes em se manifestarem anteriormente, eu suspendi essa atividade.

Também nesse momento perguntei sobre qual atividade eles gostariam de fazer no momento da integração, no próximo encontro realizado no Coletivo da Cidade e, dentre as sugestões que eles mesmos apresentaram - como caça ao tesouro, cobra cega pique pega -, a caça ao tesouro foi escolhida. Definimos como seria a dinâmica no dia, quem falaria as dicas e quem as criaria, quem providenciaria e esconderia o tesouro e as opções de tesouro.

Posteriormente foi realizada a atividade Máquina e fotógrafo com revelação para introduzir o esclarecimento de como se opera uma máquina fotográfica de forma lúdica, bem como questões, tais quais cuidado com o equipamento, processo de revelação de imagens e respeito ao trabalho do colega. Na atividade se formavam duplas e uma pessoa fechava os olhos, sendo a máquina, e a outra a conduzia pelos espaços, sendo a fotógrafa. Quando queria realizar um registro, tocava no ombro de quem representava a máquina. Depois, quem era a máquina trocava com quem era a fotógrafa. Ao final, formava-se um círculo e cada uma recebia uma folha para registrar, em giz branco, o que havia visto, para depois passar em uma vasilha com água e anilina e o desenho aparecer.

Acompanhando seu desenvolvimento, percebi que as crianças estavam dispersas e muito mais motivadas a terem o contato com o equipamento, mas, mesmo assim, foi possível destacar a necessidade de se estabelecer uma relação de cuidado, pois, "de brincadeira", duas crianças tinham provocado o choque entre as máquinas e uma delas havia se machucado. Aproveitei para chamar a atenção sobre a necessidade de agir com responsabilidade no espaço.

Após revelarmos as imagens, nós as discutimos. Todos haviam realizado desenhos de computadores (pois a sala que usávamos era a sala de informática da entidade), mas cada um tinha feito um desenho único, destacando ou omitindo elementos das mais variadas formas, compondo a imagem muito especificamente. 
Como Higuchi e Kuhnen (2008) sugerem ao descreverem a técnica Fotografando ambiente, a instrução sobre o uso da câmera fotográfica foi feita durante a etapa da criação. Diante dos acontecimentos, optei por disponibilizar as informações relativas ao uso das câmeras, informações sobre o manuseio e orientações sobre luz-foco-sombas e cores, por exemplo, à medida que apareciam na própria vivência com os equipamentos. $O$ foco dado durante as atividades foi mais no sentido de incentivar a liberdade criativa e as diversas possibilidades de olhares.

A turma foi dividida em duas duplas e um trio, para realizarem fotos no próprio espaço educativo com máquinas disponibilizadas por mim. Nesse caso, o registro fotográfico serviu como teste para auxiliar na produção de imagens sobre a cidade, que seria feita em horário e dia combinados. Para o registro fotográfico, nesse momento, foi dado o seguinte comando: "divididos em grupos, cada um fará uma fotografia de algo que mais the desperte a curiosidade no Coletivo da Cidade". A instrução dada era que eles fizessem apenas uma fotografia de todo o visível fotográfico e depois voltassem para sala para colocarmos no computador, visualizarmos e discutirmos. Ao propor que eles fizessem apenas uma foto, todos reclamaram e a ideia de usarmos o computador na atividade os deixou motivados. Como estávamos utilizando a sala de computadores, em vários momentos eles queriam usá-los e chegaram a ficar até mesmo resistentes a realizar outras atividades que não fossem sair para fotografar ou usar o computador.

Eles tiveram que se organizar em relação a quem iria realizar a fotografia e poderiam transitar por todos espaços do Coletivo.

Foram disponibilizadas três câmeras digitais (duas máquinas Kodak Easy Share M340 com especificações, 10 mega pixels e zoom óptico de 3x e uma Samsung D-240, 12.2 mega pixels e zoom óptico 5x). No momento da distribuição houve tumulto para ver quem ficaria com qual máquina, em virtude das características externas dos equipamentos e, sendo assim, realizei sorteio. Estavam tão entusiasmados que nem queriam ouvir instruções sobre uso da máquina. 
Quando entreguei as máquinas, nem cheguei a dar instruções básicas de

como ligar e sobre em qual botão era feito o registro, e alguns já estavam fotografando ou mexendo na câmera por eles mesmos. Além disso, enquanto eu tentava explicar, a Bia e a Cassi, que formavam uma dupla, discutiam sobre quem iria segurar a máquina.

Discutimos as fotos, ao exibirmos as imagens da primeira dupla após enfrentarmos problemas técnicos com o equipamento de projeção.

Fechamos o encontro conversando sobre o passeio que iríamos fazer no próximo. Não tivemos tempo hábil para que cada um colocasse suas impressões sobre este encontro.

No primeiro encontro (em 25 de abril), as atividades contribuíram para suscitar o entrosamento dos participantes, o contato com o equipamento fotográfico e iniciar o trabalho sobre percepção do ambiente, bem como a leitura das imagens fotográficas.

\subsubsection{Encontro 2}

Para a realização dessa atividade foi enviado aos pais um bilhete informando o dia e solicitando que os alunos não faltassem.

Entre os dias 27 de abril e $1^{\circ}$ de maio, realizei passeio pela Cidade Estrutural em pequenos grupos, divididos em virtude da proximidade de moradia e facilidade de contato prévio para agendamento do passeio, que ocorreu sempre durante o horário que as crianças frequentam o Coletivo da Cidade.

Primeiro com a Bia e a Cassi, depois com João Victor, que faria o passeio com a Jaque, mas que deixou de participar das atividades do Coletivo da Cidade para entrar em uma escolinha de futebol e assim não mais participou conosco da oficina. Por último, com a Yohanninha, o Pedro e a Fran.

Apenas no primeiro dia uma pessoa nos acompanhou para me dar suporte.

$\mathrm{Na}$ fase de integração foi apresentado o mapa da cidade e consultadas referências de alguns lugares para as crianças, bem como confirmado o caminho 
percorrido da escola ao espaço educativo. Em geral, as crianças tinham dificuldade de apresentar pontos de referência e visualizar o trajeto realizado cotidianamente no mapa. Nessa atividade destacamos a via Estrutural, as entradas para Cidade Estrutural, o posto policial, o Coletivo da Cidade e os locais das casas.

Nem todos do grupo tinham costume de andar pela cidade por áreas mais distantes de suas moradias, mas todos iam a pé de suas casas para o Coletivo da Cidade, na companhia de amigos e/ou familiares e conheciam essa região.

$\mathrm{Na}$ fase de sensibilização foi destacado que cada um tinha liberdade para fotografar o que considerasse objeto de registro, de acordo com a proposta de trabalho. Foi esclarecido às crianças que, para realizarem imagens de pessoas, teriam que obter autorizações por escrito (APÊNDICE E) destas pessoas ou de seus responsáveis ( no caso de crianças).

Foi solicitado a cada criança realizar três fotografias: uma do que considerasse bom da cidade, outra do que considerasse ruim e mais outra de algo que the chamasse a atenção (livre).

O registro fotográfico foi realizado com uma máquina disponibilizada por mim a cada um dos participantes durante o passeio (as mesmas usadas no encontro anterior).

Durante o passeio percorremos a pé as ruas da Cidade Estrutural, realizando, inicialmente, o trajeto do Coletivo da Cidade à casa das crianças, porém elas foram indicando os lugares a serem percorridos no tempo disponível que tínhamos, para que fizessem o registro fotográfico.

Com a Bia e a Cassi percorri as ruas próximas à residência delas. Saímos do Coletivo da Cidade e caminhamos por onde elas normalmente passam para chegar de suas casas. Primeiro passamos em frente a casa da Cassi, conheci seu irmão que brincava na rua; depois passamos em frente a casa da Bia e, nesse momento, elas sugeriram que circulássemos pela região. Durante o trajeto, Bia sempre destacava as casas de seus familiares, madrinhas, avós. Em um momento do passeio encontramos a tia da Cassi, responsável legal por ela, que nos convidou para tomar água em sua casa. Neste momento aproveitamos 
para descansar, já que, posteriormente, retomaríamos o passeio. Depois percorremos as ruas próximas de lá.

Quando já estávamos há aproximadamente 50 minutos circulando, perguntei a elas quantas imagens faltavam e, até o momento, cada uma havia feito apenas duas fotos para a atividade (Cassi a boa e a ruim, e Bia a boa e a livre) e solicitei que caminhássemos por onde elas iria realmente conseguir finalizar o trabalho. Bia nos conduziu para que tirássemos as fotos. Ao final, voltamos para o Coletivo.

Com Pedro, Fran e Yohaninha iniciamos o percurso passando em frente a casa da Yohaninha, depois seguindo em direção a casa de Pedro que, desde o início, havia manifestado interesse em fotografar seu irmão. Chegando lá fomos recebidos pela mãe de Pedro, que estava com os outros filhos em casa. Depois de Pedro realizar as fotos, saímos, passamos em frente a casa da Fran e as crianças sugeriram que fôssemos em direção "às casinhas", que ficam ainda no Setor Oeste, porém mais afastadas do local de residência das crianças, por considerarem que lá havia mais elementos para tirarem as fotos. Circulamos por lá, parando para tomar água em uma venda e retornamos ao Coletivo da Cidade passando novamente pela casa de Pedro.

Ao final do passeio com cada um dos grupos, realizamos a atividade Conte-me sobre a foto, após cada um selecionar 3 fotos. A medida que eu ia realizando questões para instigarem as crianças a refazerem mentalmente a trajetória, destacando os sentidos mobilizados e os sentimentos identificados e cada criança falou sobre os conteúdos internos das imagens selecionadas.

Nesse momento, grande parte das crianças teve dificuldade em responder as questões apresentadas. Dessa forma, os encontros posteriores foram elaborados a fim de possibilitar uma melhor compreensão das imagens, levando em consideração esse desafio. Os resultados são apresentados e discutidos no próximo capítulo. Optei por não usar as fotos produzidas pelo Gênio, pois este, depois do dia em que realizou a fotografia, não participou mais das atividades porque começou a frequentar a escolinha de futebol. 
Segue, abaixo, a tabela com nome da foto, classificação, autor e questões socioambientais desveladas.

Tabela 2 - Foto, classificação, autor e questões socioambientais desveladas

\begin{tabular}{|c|c|c|c|}
\hline Autor & Nome da Foto & Classificação & $\begin{array}{c}\text { Questões } \\
\text { socioambientais } \\
\text { desveladas }\end{array}$ \\
\hline Cassi & Plantas no Chão & Livre & Áreas verdes \\
\hline Cassi & Corrida & Bom & $\begin{array}{l}\text { Mobilidade e } \\
\text { infraestrutura urbana }\end{array}$ \\
\hline Cassi Bia & Chão Vermelho & Ruim & $\begin{array}{l}\text { Mobilidade e } \\
\text { infraestrutura urbana }\end{array}$ \\
\hline Bia & Fael Fofinho Viver & Livre & $\begin{array}{l}\text { Convivência familiar e } \\
\text { comunitária }\end{array}$ \\
\hline $\mathrm{Bia}$ & Flor Rosa & Bom & Áreas verdes \\
\hline $\mathrm{Bia}$ & Lugar ruim & Ruim & $\begin{array}{l}\text { Convivência } \\
\text { comunitária }\end{array}$ \\
\hline Fran & Criança livre & Livre & $\begin{array}{l}\text { Lazer e infraestrutura } \\
\text { urbana }\end{array}$ \\
\hline Fran & Criança na árvore & Bom & $\begin{array}{l}\text { Áreas Verdes, } \\
\text { Convivência } \\
\text { comunitária }\end{array}$ \\
\hline Fran & Lixo ruim na rua & Ruim & $\begin{array}{l}\text { Resíduos Sólidos e } \\
\text { infraestrutura urbana }\end{array}$ \\
\hline Yohaninha & Dentro do mato & Livre & $\begin{array}{l}\text { Áreas verdes e } \\
\text { infraestrutura urbana }\end{array}$ \\
\hline Yohaninha & Folhas verdes & Bom & Áreas verdes \\
\hline Yohaninha & Lixo no campinho & Ruim & $\begin{array}{l}\text { Resíduos Sólidos e } \\
\text { infraestrutura urbana }\end{array}$ \\
\hline Pedro & $\begin{array}{l}\text { Cavaleiro } \\
\text { Fantasma }\end{array}$ & Livre & $\begin{array}{l}\text { Áreas verdes e } \\
\text { Convivência familiar e } \\
\text { comunitária }\end{array}$ \\
\hline Pedro & Fofo & Bom & $\begin{array}{l}\text { Convivência familiar e } \\
\text { comunitária }\end{array}$ \\
\hline Pedro & O lixão & Ruim & $\begin{array}{l}\text { Resíduos Sólidos e } \\
\text { infraestrutura urbana }\end{array}$ \\
\hline
\end{tabular}

Fonte: Dados da pesquisa, 2012.

\subsubsection{Encontro 3}


No momento de integração realizamos a atividade Caça ao tesouro, sugerida pelas crianças. Eu providenciei os "tesouros"- um caderno para cada um - e escondi em uma sala, dentro de uma lixeira que estava preparada para recebê-lo. Fran, ao longo da brincadeira, deu as dicas e, depois de muito procurarem, Yohanninha descobriu o local. Ao receberem o tesouro, apenas Bia não reagiu com empolgação e gritos de alegria, mas, ao saber que eles poderiam levar para casa e fazer dele um diário para escreverem o que quisessem, ela mudou sua expressão de descontentamento e gostou da ideia, chegando a perguntar se poderia, naquele momento, já escrever e desenhar no caderno.

Nesse encontro tive dificuldade para conduzir as atividades com o grupo e, ao mesmo tempo, cuidar do equipamento de gravação. Só após a segunda atividade iniciei a gravação. Também tive dificuldade na condução da oficina, já que ficamos em um corredor com sofá e em que várias pessoas passavam; assim o grupo tinha dificuldade para se concentrar e realizar as atividades.

$\mathrm{Na}$ segunda atividade, já de sensibilização, entreguei para cada um as três fotos selecionadas impressas em papel fotográfico. Em seguida, solicitei que cada um escrevesse um título para a própria foto.

Nesse momento eles começaram a visualizar as fotos dos colegas. Alguns haviam esquecido a classificação dada para cada foto (livre, algo ruim na cidade e algo bom na cidade) e aproveitamos para esclarecer.

Quando terminaram, solicitei, já no momento de criação, que cada um apresentasse a sua fotografia. Nesse momento cada um falou sobre o período do registro de cada foto, alguns chegaram a destacar, inclusive, determinados elementos até então não revelados no encontro anterior. Yohaninha, que precisava sair para fazer outra atividade, começou, seguida de Fran, Pedro, Cassi e Bia. Durante a atividade, alguns se incomodaram com o fluxo de pessoas circulando por onde estávamos.

Para esta atividade eu havia preparado alguns apontamentos, de modo a realizar em cada apresentação, o que, pela dinâmica e interação do grupo, fui colocando quando possível. 
Ao final recolhi todas as fotos impressas e entreguei novamente a eles três fotos sorteadas das 15 disponíveis. Ao longo da semana, eles teriam que descrever a foto, falar sobre as cores, os elementos presentes nela e o assunto abordado, bem como alguma história que ela pudesse lembrar. Assim cada um poderia compartilhar sua perspectiva em relação ao trabalho do colega.

Ao distribuir as fotos, alguns reclamaram das que receberam e se mostraram resistentes a fazerem a atividade.

Para encerrar, definimos a atividade que seria feita no início do próximo encontro, dentre as sugestões: jogos, realizar novo passeio e usar o computador. Foi decidido que, estando a sala disponível, as crianças iriam usar o computador de forma livre.

\subsubsection{Encontro 4}

Nesse dia a Yohaninha faltou o encontro sem justificar a ausência.

No momento de integração, as crianças presentes (Pedro, Cassi, Bia e Fran) usaram o computador de forma livre: aproveitaram para pesquisar vídeos e músicas, usar programas de desenho, jogar na net e tentar entrar em uma rede social. Ao final, eu perguntei se alguém havia usado o computador para fazer pesquisa e Pedro respondeu que sim, para ver uma cena de uma novela a que ele assistia.

Aproveitei para fazer relação do que Pedro havia pesquisado com a possibilidade de se construírem narrativas por meio de imagens sem movimento, no nosso caso imagens fotográficas. Após discutirmos sobre o assunto, tendo como exemplo uma foto feita pela Yohanne, a própria Fran sugeriu que o grupo fizesse um texto no computador sobre as histórias das fotografias realizadas. Com isso, retomei o exercício que havia passado na semana anterior escreverem sobre as fotos - e, aos poucos, eles compartilharam o que haviam escrito. Pedro começou falando sobre o que escreveu e o que teve dificuldade de escrever, seguido de Fran. Em seguida Bia deu continuidade, dizendo o que refletiu sobre as imagens que estavam com ela e Cassi. 
Após essa atividade, a proposta inicial era que eles pesquisassem fotógrafos profissionais e depois pensassem uma forma de apresentar as próprias imagens, mas, como a Fran havia sugerido que continuassem a escrever no computador, mudei o roteiro e propus que eles pesquisassem na internet sobre os temas de cada fotografia e continuassem a escrita do texto sobre as fotos no computador.

Embora no momento anterior, de uma forma geral, eles tivessem demonstrado familiaridade com o computador, nesse momento sentiram dificuldades em encontrar o programa para escrever o texto, em digitar, além de propriamente escrever o que queriam e corrigir os erros de português.

Após uma hora, encerramos esta atividade e devolvi para cada um as fotos impressas. Depois combinamos o que seria realizado no próximo encontro: um passeio para conhecermos exposições no Centro Cultural Banco do Brasil e Espaço Cultural Contemporâneo (ECCO).

Como finalização, iniciamos uma atividade para relembrarmos o que havíamos realizado até aquele encontro e avaliarmos a oficina, no entanto, interrompemos quando Fran passou mal e o tempo se esgotou.

\subsubsection{Encontro 5}

Foi informado aos pais sobre o passeio e solicitada autorização por parte da equipe do Coletivo da Cidade. Este passeio aconteceu em um domingo (data acertada com todas as crianças, de acordo com a disponibilidade de todos e facilidade de transporte). Em companhia de uma amiga, busquei as crianças na porta do Coletivo da Cidade e, de carro, nos dirigimos ao espaço ECCO. Nesse dia a Fran não estava presente e em todo o percurso eles tinham disponíveis as três máquinas, para se organizarem e tirarem fotos.

No Espaço ECCO acontecia uma mostra de fotografia intitulada Retinas e rotina. $\mathrm{Na}$ ocasião eram apresentadas fotografias tiradas por crianças e adolescentes em oficinas realizadas em diferentes estados. As crianças e 
adolescentes cumpriam medidas socioeducativas sobre o cotidiano nas unidades de internamento. A exposição havia sido organizada pela Andi como parte das ações do evento Direitos em Pauta - imprensa, agenda social e conflito com a lei, que aconteceu em Brasília nos dias 22 a 24 de maio de 2012.

Nesse local aproveitei para destacar as necessidades de se garantirem os direitos das crianças e adolescentes e refletimos sobre as condições de vida dos que ali estavam fotografando, mas o enfoque dado foi para a forma com que o trabalho estava sendo apresentado e nossa interpretação.

As respostas foram consideradas na categorização das questões reveladas a partir das fotos realizadas pelas crianças. Comecei a atividade mostrando para eles as próprias imagens realizadas e indagando sobre quais eram os direitos que eles consideravam que as fotos ressaltavam; depois reforcei a importância deles para o desenvolvimento das crianças e adolescentes.

Destaquei que muitos dos meninos e meninas que ali estavam apresentando seu cotidiano haviam tido seus direitos negligenciados e não garantidos e que isso os prejudicava. $\mathrm{Na}$ ocasião, Yohaninha deu um depoimento comovente sobre uma situação que tinha presenciado naquela semana: o assassinato de um vizinho usuário de drogas bem em frente a casa dela.

Depois circulamos pelo espaço, lemos sobre os trabalhos expostos, começando com a apresentação geral da curadoria e fizemos uma reflexão sobre o conteúdo. Os textos estavam escritos com palavras muito difíceis para as crianças, mas, mesmo assim, elas se interessaram em ler e ver as fotos e compreender o contexto dos trabalhos. Nosso esforço interpretativo estava baseado em algumas perguntas: quem fez o registro, como fez e qual o momento. Na medida em que íamos lendo as apresentações, íamos identificando possíveis respostas para as perguntas e questões como "porque sonhos velados", apresentados pela Yohaninha, eram discutidas pelo grupo.

Elas apenas ficaram muito desmotivadas com o lugar, que estava muito sujo. Na noite anterior houve uma festa e, no momento em que estávamos lá, pessoas limpavam e desmontavam a estrutura. 
Saímos de lá e fomos para o Centro Cultural Banco do Brasil. Quando chegamos, lanchamos ao ar livre e eles brincaram nos jardins. Depois vimos a exposição Índia, que reunia mais de 350 peças variadas, como artefatos sacros, estátuas, fotografias e vídeos e apresentava, criativamente e de forma diversificada, a cultura Indiana.

$\mathrm{Na}$ ocasião pensamos em possibilidades de apresentação do trabalho deles e dos procedimentos necessários para isso (elaboração da proposta expográfica, montagem das peças, captação de recursos, exercício da criatividade para montagem das peças e reutilização de materiais).

Eles estavam muito interessados em fotografar tudo e, por terem que se organizar para compartilharem o equipamento, conflitos entre eles emergiram, chegando ao ponto de, ao final, pararmos para conversar, avaliarmos o que estava acontecendo e juntos definirmos uma estratégia para resolver o conflito.

Saímos do Centro Cultural Banco do Brasil e as crianças foram deixadas na porta de casa.

\subsubsection{Encontro 6}

Quando cheguei ao Coletivo, a sala que iria usar não estava disponível e não tínhamos local para fazer nossa atividade. Ficamos numa mesa, em um local muito barulhento e, nesse momento, comecei a sentir enxaqueca.

A Fran também não participou nesse dia, sem justificar sua ausência. Ao final do encontro, a achei para entregar o $c d$ e perguntar sobre o que estava se passando e ela disse que no dia queria fazer atividade de recreação, mas que não queria deixar de participar.

Havíamos programado de usarmos o computador para visualizarmos as imagens feitas e discutirmos a forma de apresentação das fotos, no entanto, não pudemos usar os computadores e eu apenas entreguei a eles um $c d$ com todas as fotos que haviam sido feitas durante nossos encontros anteriores. 
Como não pudemos executar o planejado, retomei a atividade de reconstrução do percurso, até então trilhado na oficina e que não pode ser concluída no encontro quatro. Nesse dia apenas fizemos uma roda de conversas.

Relembramos coletivamente todas as atividades realizadas $\mathrm{e}$ conversamos as situações que vivenciamos.

$\mathrm{Na}$ ocasião tivemos a oportunidade de conversar sobre os conflitos cotidianos e as formas de resolução. Apresentei algumas questões norteadoras de como são comumente resolvidos e apresentei uma nova perspectiva.

Nesse dia eu estava um pouco emotiva por questões pessoais e, pelo contexto da ausência de infraestrutura no dia, bem como pela finalização da oficina, as crianças perceberam, pela minha expressão, que algo não estava bem comigo e pediram para contar para eles o que estava se passando. Resisti, mas eles começaram a levantar hipóteses e a me perguntar. Daí expliquei, dentro do que era possível, o que se passava, em especial meu incômodo com a ausência de infraestrutura e os recursos necessários para a atividade. Eles demonstraram interesse em continuar nossos encontros e, inclusive, em ajudar para que a oficina não terminasse, chegando até a propor guardarem dinheiro em cofrinhos e pedir ajuda de pais, para que atividade continuasse. Reforcei a importância da participação dos pais, mas sugeri que fosse pensada outra alternativa, alguma em que pudéssemos conseguir maior apoio e em que eles não tivessem que trabalhar, pois, pela idade deles, o foco que lhes caberia seria estudar e se divertir, não trabalhar.

Acertamos que, além do encontro de encerramento da oficina, teríamos outro para planejar a exposição dos trabalhos. Retomamos uma ideia que surgiu da apresentação dos trabalhos quando estávamos no Centro Cultural Banco do Brasil, que era a de montar uma peça para exposição, trazendo a importância da convivência entre as crianças e o crescer em um ambiente apropriado. No caso, imprimiríamos as fotos em tecidos e montaríamos uma mandala com patchwork (técnica de costura com retalhos de tecido), com a qual um grupo de mães já trabalhava. Pensamos que no centro da mandala poderia ter alguma frase que 
provocasse a reflexão e que embaixo dela deixaríamos bonecos de pano, com diferentes fisionomias, de mãos dadas. Acertamos que seria interessante o grupo aprender a fazer os bonecos com alguma senhora que, quando criança, tivesse brincado com tais tipos de bonecos.

Paralelo à construção de ideias para superar o desafio posto para eles de forma espontânea, conversamos sobre assuntos diversos, inclusive sobre a violência na Estrutural, já que alguém abordou o assunto ao ver viaturas policiais, dizendo ter medo deles.

Ao final nos despedimos, combinado o encontro com a participação dos pais.

\subsubsection{Encontro 7}

O encontro não foi gravado, por problemas técnicos. Aconteceu fora do horário de atendimento durante a semana, ao sábado, em virtude da disponibilidade de espaço e da possibilidade de os pais participarem.

Estavam presentes a Cassi, a Bia, a prima e a mãe da Bia e eu.

Comecei a atividade apresentando as fotos e a dinâmica da oficina para a mãe da Bia e para a prima. Coloquei as fotos impressas em um mural e agrupei pelas questões socioambientais que eu havia identificado e solicitei que se manifestassem sobre a forma com que eu organizei a leitura coletiva das imagens.

Conversamos sobre as possibilidades de apresentar o trabalho e a Cassi sugeriu que fizéssemos um texto falando sobre como é andar pela Cidade Estrutural e, a partir daí, eu propus a atividade chamada História dobrada. Nesta atividade, cada um do grupo escreve uma parte da história, dando continuidade ao ler a frases deixadas pela pessoa anterior, só tendo acesso a essa parte específica da história.

Após escrevermos o texto, lemos e discutimos seu conteúdo e, a partir do que discutíamos, alteramos o original, tornando-o mais compreensível e também trazendo informações complementares para história, ao passo que refletíamos 
sobre ela. Esta história colocou em evidência vários aspectos desvelados pelas imagens e está apresentada no próximo capítulo.

Ao final, fomos até o Ponto de Memória da Cidade, local que poderia abrigar nossa exposição por trabalhar com a memória da cidade e desenvolver outros projetos na comunidade.

Terminamos lanchando e eu deixando cada um na porta de sua casa.

\subsubsection{Encontro 8}

Este encontro foi iniciado com a apresentação do material produzido no último encontro e depois eles sugeriram que fizéssemos fotos do grupo, pois, como Cassi propôs, eu poderia imprimir e colocar na minha mesa de estudo para lembrar deles. E assim encerramos, realizando fotos do grupo, conforme sugerido pelas crianças, e eu fiquei de retomar posteriormente os resultados da articulação e do trabalho para lá continuar realizando a oficina.

$\mathrm{Na}$ mesma semana eu estava escrevendo um projeto para financiamento de ações culturais e, assim, expliquei a eles os procedimentos, para não gerar expectativas inviáveis e contextualizei a possibilidade de darmos continuidade à oficina.

\subsection{Análise}

Especificamente em relação às fotografias, destacamos que estas foram analisadas de acordo com o indicado por Kossoy $(2002,2009)$ e reiterado por Higuchi e Kuhnen ( 2008, p, 198) ao proporem que a leitura das imagens seja feita apontando "a escolha do foco, a imagem, os conteúdos internos que the inspiram na busca da imagem para representar a indagação".

As fotos foram descritas, contextualizadas e interpretadas, bem como apresentadas a partir da narrativa construída por mim e discutida com as crianças. 
A partir da elaboração do diário de bordo e da transcrição das gravações, foi realizada uma leitura flutuante (ANDRÉ, 2008), com a identificação de categorias de análise que subsidiaram a contextualização e a interpretação das fotos e a construção da narrativa.

\section{AS QUESTÕES SOCIOAMBIENTAIS DA CIDADE ESTRUTURAL A PARTIR DAS FOTOGRAFIAS DAS CRIANÇAS}

A primeira realidade, ou seja a realidade no contexto da produção das imagens, foi vivenciada no cotidiano das ruas da Cidade Estrutural, no setor Leste, que se revelava ao circularmos pela cidade no período indicado e contextualizado no capítulo 6 .

A partir do registros fotográficos realizados no segundo encontro da oficina durante passeio pela Cidade Estrutural e das discussões e atividades realizadas nos demais encontros fomos elaborando nossa compreensão da segunda realidade, ou seja a interpretação dos fragmentos congelados da cena presentes das fotografias.

Para isso é importante destacar que ao longo dos encontros 3, 4, 5, 6, 7 e 8 , as crianças destacaram nas fotografias aspectos já sinalizados por Kossoy(2002,2009 que influenciam a leitura das imagens. São eles:

- Os elementos presentes e a primeira realidade fotográfica;

- As cores;

- A autoria;

- Aspectos relativos à qualidade técnica das imagens;

- Se haviam gostado ou não da foto em virtude do apresentado anteriormente 
Assim, a leitura das imagens revelaram não só aspectos relacionados ao domínio e especificidades do equipamento usado mas também à elaboração criativa e estética das crianças, bem como aos temas abordados. Os temas foram categorizados considerando as narrativas (compreendendo contextualização e interpretação das fotografias) construídas a partir das indagações elaboradas durante a leitura coletiva das fotografias. A partir do registros do que achavam bom, ruim e o que queriam destacar da cidade, tivemos como resultado 12 fotografias indicando 3 temas específicos interrelacionados.

Vejamos abaixo um mosaico com as fotos realizadas que serviram de base para a elaboração da narrativa. O mosaico foi organizado colocando na primeira parte as fotos agrupadas tendo cada coluna representando cada de uma das 5 crianças participantes (Bia, Pedro, Cassi, Yohaninha e Fran) e as linhas apresentando a foto livre, boa e ruim selecionada das mesmas. $\mathrm{Na}$ segunda parte, as fotos foram reorganizadas a partir dos temas.

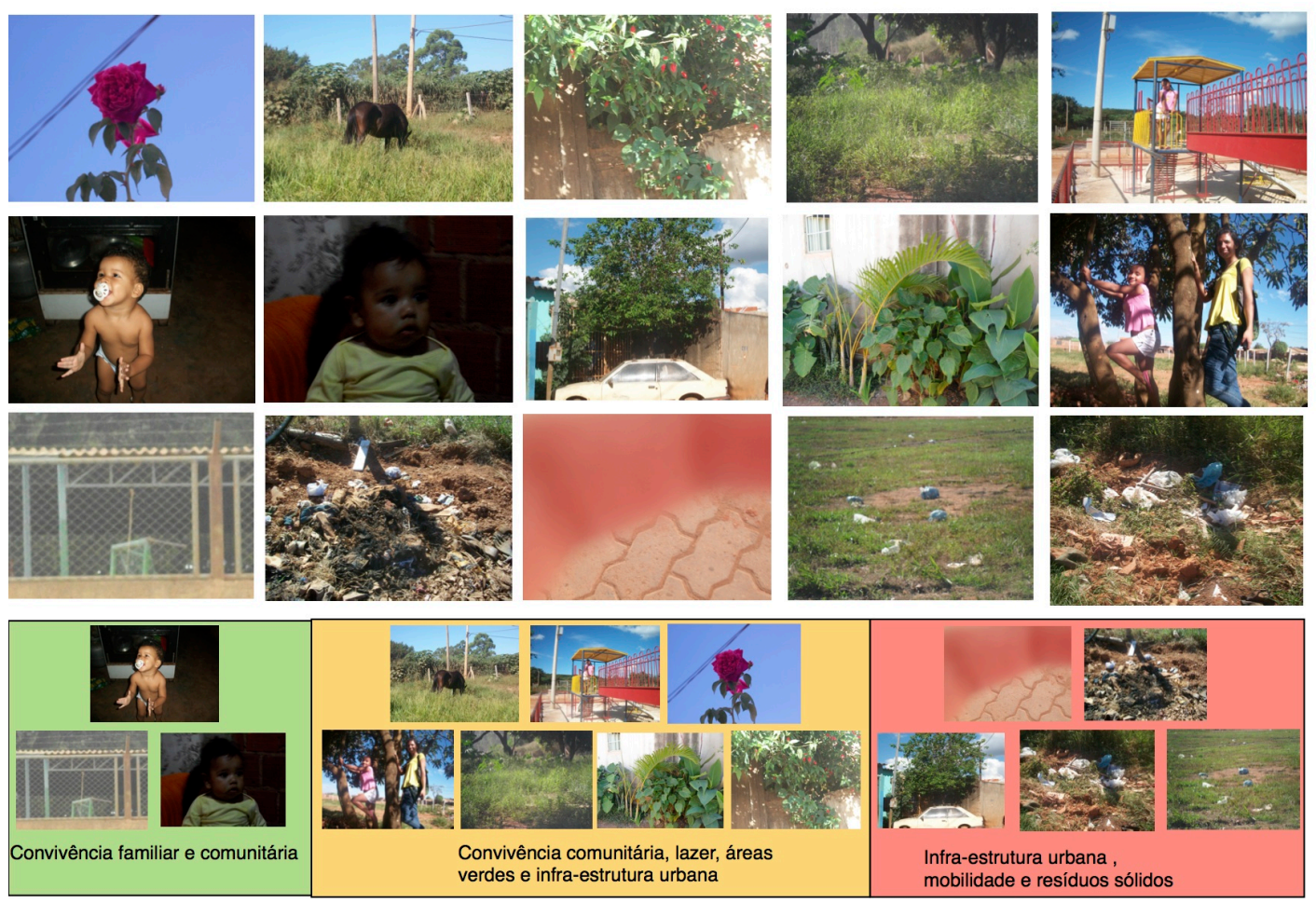


llustração 3- Fagundes, F.A. Mosaico de imagens selecionadas. Colagens com imagens fotográficas, 30 de outubro de 2012.

Os temas revelam uma forma de compreensão da relação sociedadenatureza relacionado ao mundo de vida das crianças e destacam as questões socioambientais percebidas pelas mesmas. Sinalizam uma preocupação como processo de ocupação e urbanização das periferias das cidades com implementação de infraestrutura urbana, equipamentos públicos ao passo que os vínculos comunitários e familiares, a preservação das paisagens naturais e o lazer são reforçados. O discurso que se constrói a partir da leitura das fotografias esta em consonância com as normatizações e mobilizações em prol da garantia de direitos das crianças e adolescentes e das propostas de trabalho no campo da EA. Ao longo desse capítulo narramos o discurso elaborado durante o processo de leitura das imagens, que revela o mundo de vida das crianças e detalha aspectos das questões socioambientais.

\subsection{Convivência familiar e comunitária}

Quando andávamos pela rua, encontramos com a tia de Cassi, responsável legal pela mesma, e nesse momento decidimos passar na casa dela para tomarmos água. Com a casa cheia de pessoas, fomos bem acolhidos e brincávamos com o primo de Cassi, em um momento de descontração e alegria. Bia aproveitou o momento para fotografar o primo de Cassi selecionando posteriormente a foto como algo que gostaria de destacar. 


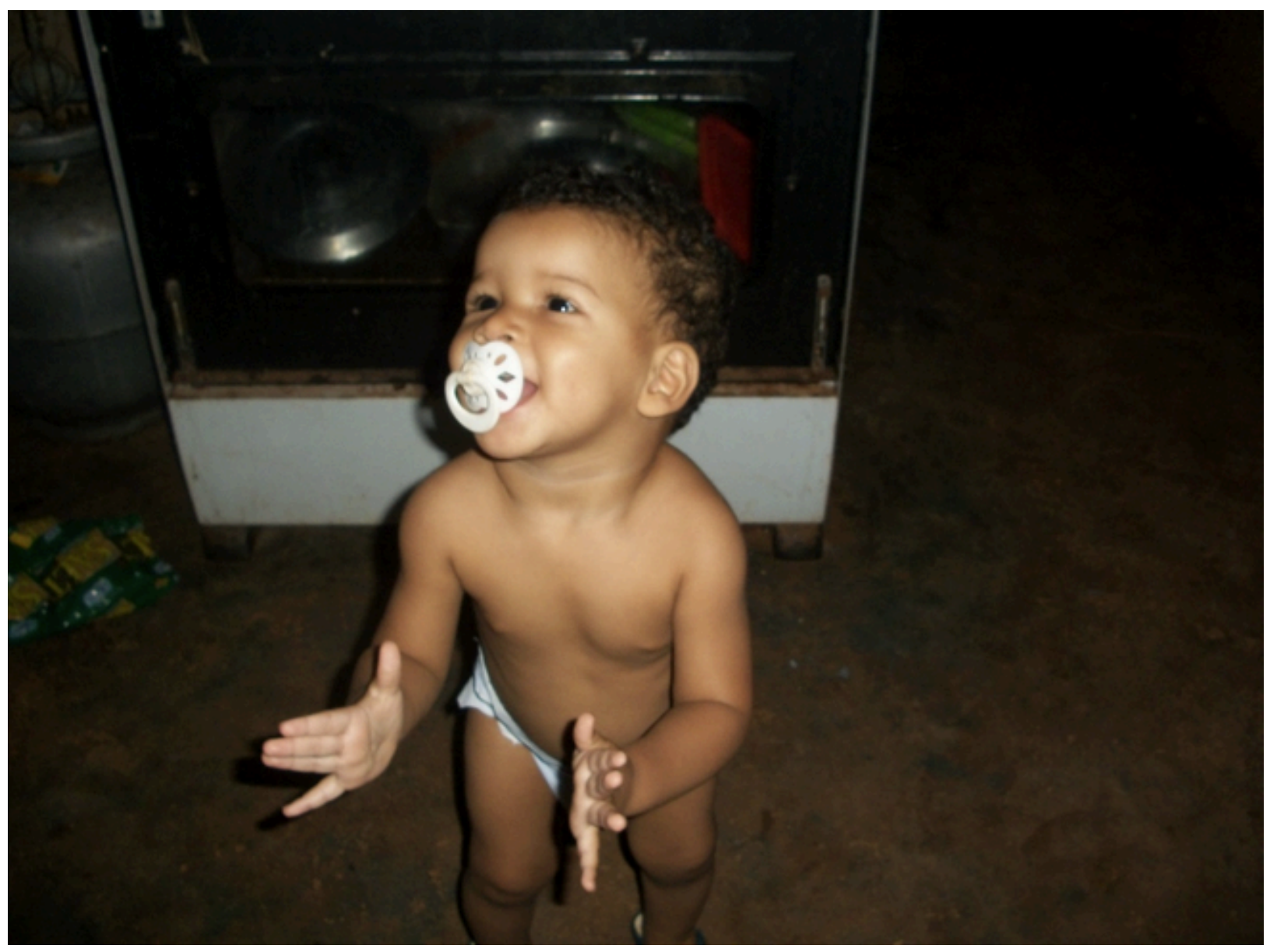

Ilustração 4 - Bia. Fael fofo. Imagem fotográfica, 03 de maio de 2012

Como podemos ver, a beleza do olhar e a presença alegre do primo de Cassi se mostram evidentes naquele ambiente com estrutura simples- chão de terra cozida (uma técnica construtiva popular que usa poucos recursos materiais) e fogão antigo.

Os movimentos com as mãos, aplaudindo o que estava vendo -muitas pessoas na cozinha interagindo com ele e se divertindo em um ambiente acolhedor - reiteram a importância desses momentos na vida de uma criança "fofa, bonita e gostosa" como o primo de Cassi foi descrito na dinâmica que realizamos juntos de leitura das fotos selecionadas. Momentos como esse marcam a vida de uma criança e a própria Cassi considerou aquele em sua casa como o mais interessante do passeio. 
Tanto Bia quanto Pedro selecionaram fotos de crianças familiares nas casas de estrutura simples: Bia do primo de Cassi e Pedro do seu irmão. Vejamos a foto de Pedro.

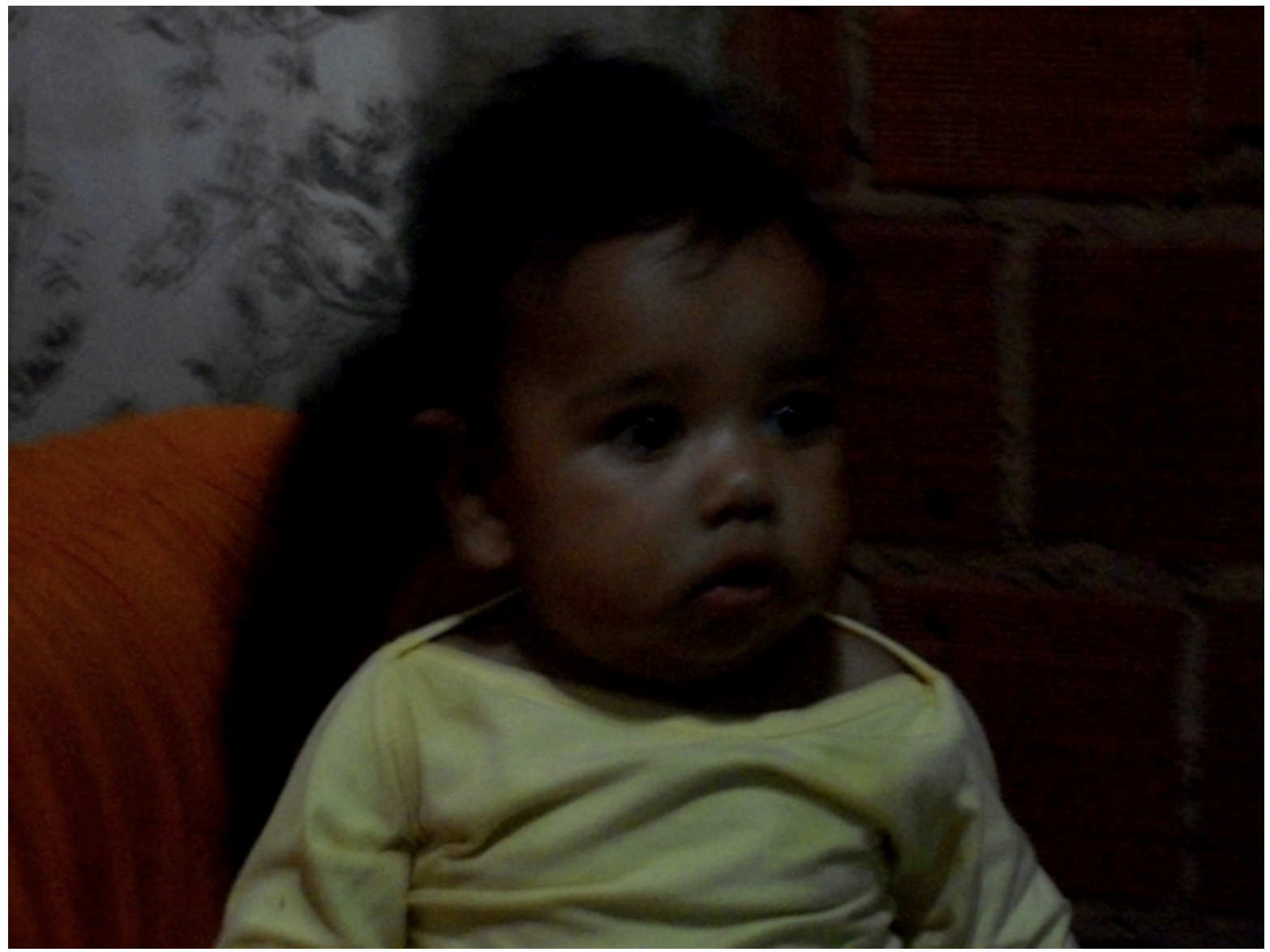

Ilustração 5 - Pedro. Fofo. Imagem fotográfica, 07 de maio de 2012

A simplicidade da infra-estrutura na foto de Pedro também é revelada pelo uso do equipamento inapropriado que em ambientes com baixa iluminação, um simples tremido pode deixar a foto desfocada, como aconteceu. Contudo, como na foto anterior, tal simplicidade da infraestrutura não ofuscou o destaque, a importância, o cuidado e o carinho concedidos às criança em seus contextos familiares, bem como o valor dado à foto.

Pedro já tinha o costume de realizar registros do irmão com uma câmera de celular da mãe, e durante o passeio aproveitou a oportunidade para usar o equipamento para fazer outras fotos e selecionar uma delas para mostrar o que há de bom na cidade, reiterando a importância daqueles momentos. 
Como muitos do grupo sinalizaram o irmão de Pedro é querido por todos da rua, "ele é o xodó da rua", nos afirmou sua mãe durante o passeio e Cassi, ao comentarem as fotos, ainda dizendo: "foto mais fofa de todas nem se compara, bochecha mais grande".

O irmão de Pedro, "cabeludinho" e também "pretinho", nas palavras de Bia, é querido na rua onde mora e apreciado pelas crianças, mas sua fisionomia, parecida com a de vários garotos da Cidade Estrutural, nem sempre é apreciada e valorizada. No local onde realizei a oficina, cheguei a presenciar momentos em que algumas crianças se referiam às outras crianças negras de maneira pejorativa. Discutindo durante a leitura das imagens com as crianças participantes da oficinas sobre a questão alguns afirmaram ser recorrente uns se referirem aos outros usando apelidos de forma pejorativa, como "macaco da áfrica", "filhote de piche", "formiga do haiti", "macaca fedorenta", "poço de lixo" e Bia inclusive nos relatou que esse foi o motivo que a fez selecionar a foto "Lugar ruim" . A foto como veremos abaixo com a sobreposição de tonalidades em tons crus das estruturas gera um desconforto no olhar. O muro, as grades os arames farpados reforçam este desconforto e nos instigam a olhar com desconfiança para o local retratado de fora. 


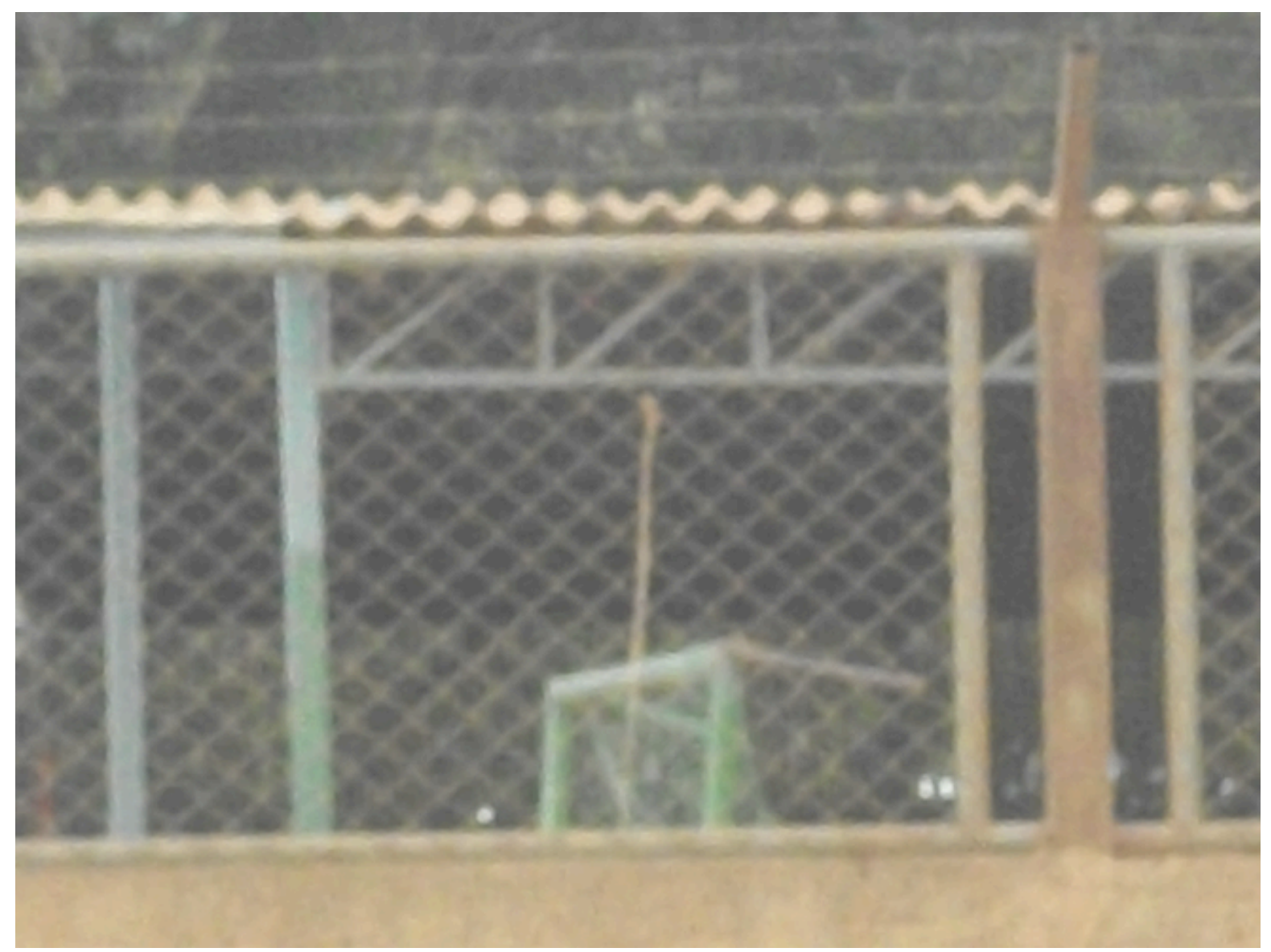

Figura 6- Bia. Lugar Ruim. Imagem fotográfica, 03 de maio de 2012

Para Bia, todo o cenário representa os momentos que vivenciou ali, quando participava de atividades educativas complementares às escolares. $\mathrm{Na}$ ocasião, era xingada por um grupo de colegas. Ela se irritava com a situação e, mesmo com a tentativa de intervenção dos responsáveis pelas atividades e com conversas entre as envolvidas, a situação não se resolveu, mobilizando emoções como as provocadas pela foto acima e motivando Bia a deixar de frequentar a entidade por causa desta situação.

Esse registro indica as consequências dos processos de discriminação que contribuem para exclusão de alguns, para a desvalorização da diversidade e lança desafios para o exercício da convivência comunitária.

7.2 Convivência comunitária, lazer, áreas verdes e infra-estrutura urbana 
Como nas imagens anteriores, a convivência comunitária e familiar também é evidenciada nas duas próximas imagens, no entanto outros elementos se destacam.

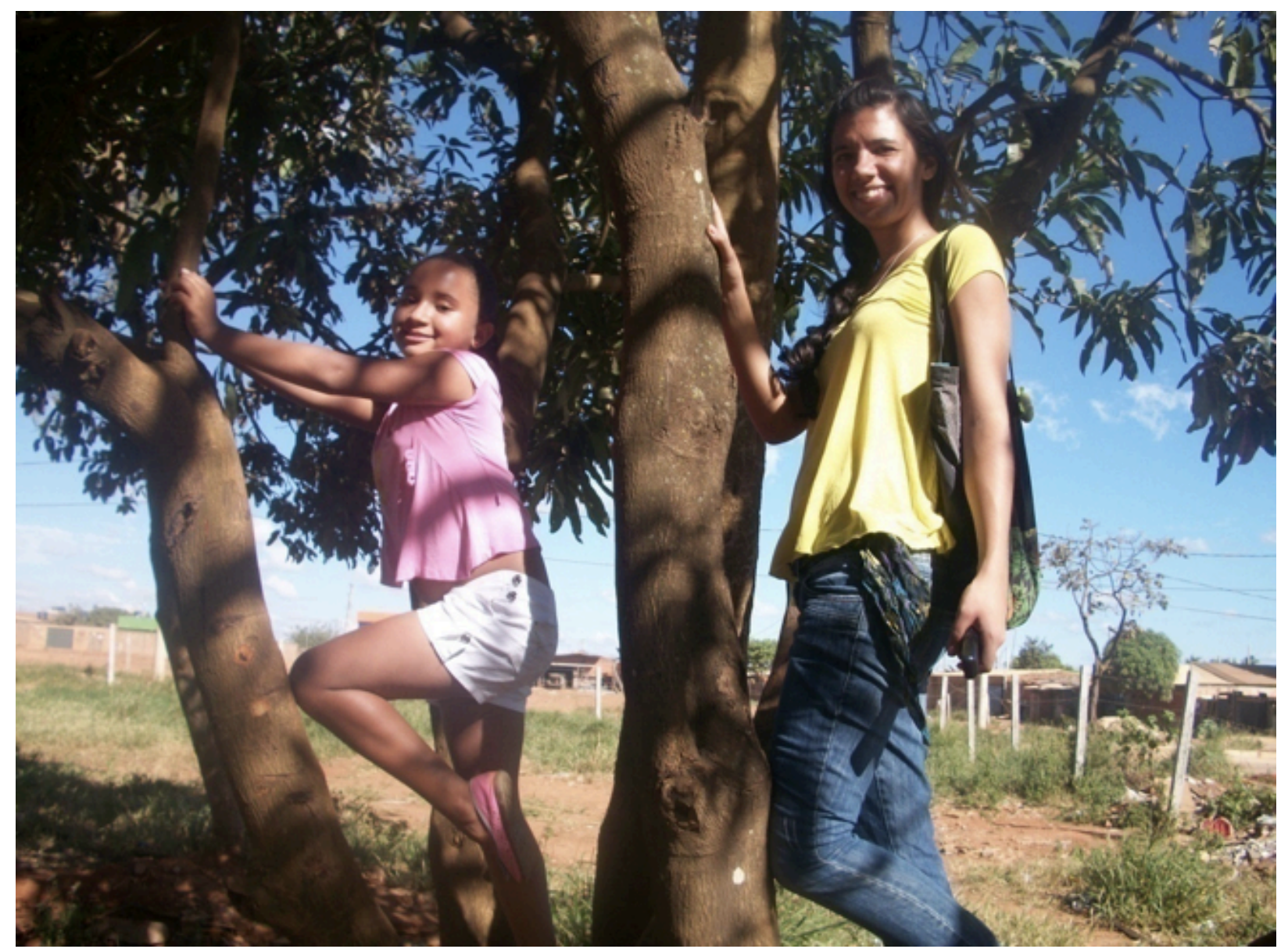

Ilustração 7 - Fran.Criança na árvore. Imagem fotográfica, 07 de maio de 2012

A foto acima, selecionada por Fran para mostrar o que há de bom na cidade foi realizada quando entramos em uma área com árvores como a dafoto e outras plantas próxima às casinhas. Eu e Fran estamos sobre uma "Mangueira" sorrindo. Fran ao apresentar a foto sinalizou o quanto foi divertido subir na árvore e relembrou outros momentos em áreas verdes com familiares ao falar sobre a foto: "quando eu vou para a Água Mineral eu subo na árvore e tiro fotos".

Pedro e Yohaninha também selecionaram fotos no local e indicaram a necessidade de preservação das áreas verdes, de lazer e interação uma vez que também sinalizaram que os espaços onde é possível circular como o que 
estivemos estão se reduzindo com a ocupação da Cidade Estrutural e aos poucos eles vão "perdendo esses espaços tão gostosos" como diz Pedro.

Quando andávamos para realizar o registro, eu, Yohanne, Pedro e Fran nos deparamos, na região das "casinhas", com um terreno cercado, com aspecto de abandonado, muitas árvores, algumas típicas do cerrado, como Cajueiro (Anacardium occidentale) e outras não. Eles solicitaram entrar lá para realizar fotos. Assim fomos. Subimos em árvores, discutimos sobre quais espécies de árvores ali teriam, quais nativas da região, brincamos no local fugindo das formigas no chão e tiramos fotos. A foto anterior e as duas próximas fotos, de Yohaninha e de Pedro, respectivamente, foram registradas neste local.

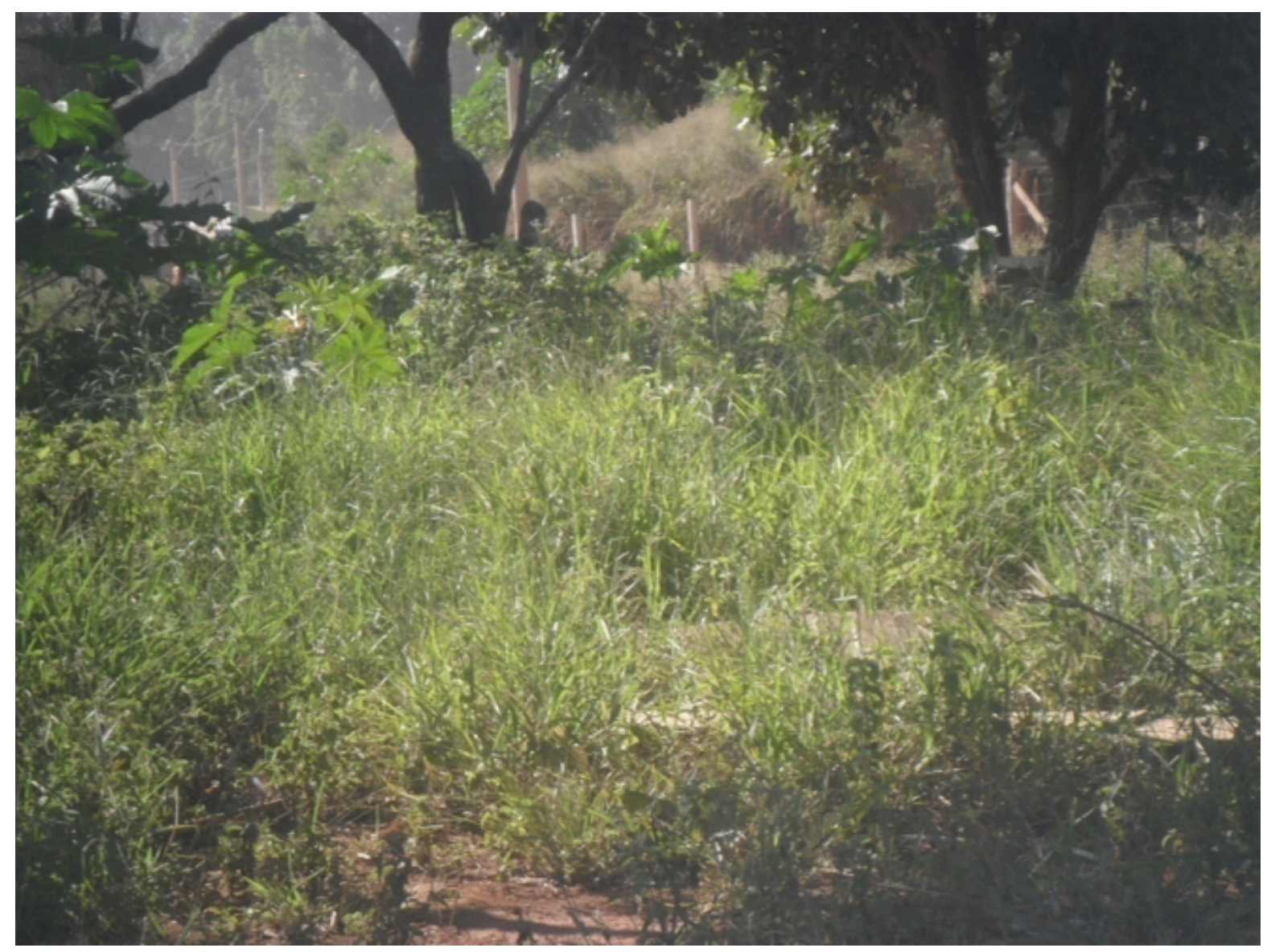

Figura 8 - Yohanninha. Dentro do mato. Imagem fotográfica, 08 de maio de 2012

Yohaninha selecionou esta foto por gostar áreas verdes e por esta área, em especial, ter uma história por ela conhecida, que queria deixar registrada como memória: naquele terreno, em meio a tantas árvores, havia uma casa, em 
que uma família vivia, no entanto a família havia sido removida e a casa demolida, para que naquele local fossem instalados equipamentos públicos.

Quando estávamos lá, brincando entre as árvores, apontei os indícios de que naquele lugar havia uma casa (os azulejos formando um piso, os entulhos), eles duvidaram, mas depois consultei uma mulher, dona da venda em frente ao terreno, na qual paramos para beber água.

Quando descansávamos, perguntei à vendedora se naquele local havia uma casa antes e a mulher respondeu positivamente, dizendo que a casa havia sido demolida para o governo fazer para instalação de equipamentos públicos.

$\mathrm{Na}$ opinião das crianças, aquela área verde estava ameaçada, assim como os momentos de descontração da turma, pois, quando perguntei se o governo iria deixar as árvores e as plantas lá, Pedro foi muito categórico, com um tom de voz como quem estivesse indignado: "não tia, com certeza não, eles não deixam". Assim, Yohanninha, naquela mesma hora, sugeriu que fosse realizado registro do local, para que, quando fosse construída alguma coisa, nós pudéssemos ter uma foto de recordação do local cheio de plantas.

Pelas três fotos acima, podemos considerar que, de acordo com as crianças, um elemento fundamental para a instalação de equipamentos públicos é a presença de áreas verdes, onde a convivência familiar e comunitária se faz de forma muito valorizada. No entanto, ainda é necessária a garantia da criação e manutenção das áreas verdes na implementação de infraestrutura por parte do governo. Para elas, um simples terreno pode se transformar em um parque de diversão e até mesmo em sala de aula ao ar livre, em que é possível abordar temas relativos às ciências, à história e à geografia em meio a diversão, descontração e alegria. Infelizmente, muitas vezes recursos públicos são gastos em obras para instalação de equipamentos públicos que vão de encontro com o que é valorizado pelas pessoas que deles usufruirão e poderão vivenciar momentos agradáveis no local.

Pedro também se identificou com o local. E lá fez o registro de um cavalo que pastava por lá. 




Ilustração 9 - Pedro. Cavaleiro fantasma. Imagem fotográfica, 08 de maio de 2012.

Pedro ao ver aquele cavalo se lembrou dos momentos que circulava à cavalo com o pai pela cidade, e também sinalizou gostar de cavalos e, por isso, se esforçou para tirar a foto. Entre o cavalo e Pedro havia um mato alto, com uma cerca de plantas de espinhos e Pedro se esforçou muito para tirar a foto do cavalo. A primeira a foto saiu apenas da anca; já a segunda saiu do animal por inteiro.

O momento do registro da foto naquele local e a reflexão sobre as duas realidades da fotografia considerando sobre possíveis desdobramentos da situação daquele terreno podem ter marcado Pedro, que nomeou a foto de Cavaleiro fantasma, fazendo referência ao filme de que gosta e cuja história trata de um homem que se vê realizando justiça com as próprias mãos contra bandidos e vilões que querem preencher o mundo com maldade. No filme o herói andando pela cidade com sem veículo preferido, faz justiça, algo que para Pedro também 
deveria acontecer para proteger o local e as crianças poderem bricar e o cavalo pastar.

Outro local da cidade é destacado pelas fotografias. Um parquinho do qual Fran reforça a alegria de poder brincar de forma livre. Ao destacar uma linda criança, em meio à estrutura do brinquedo com cores vibrantes e um céu azulado.

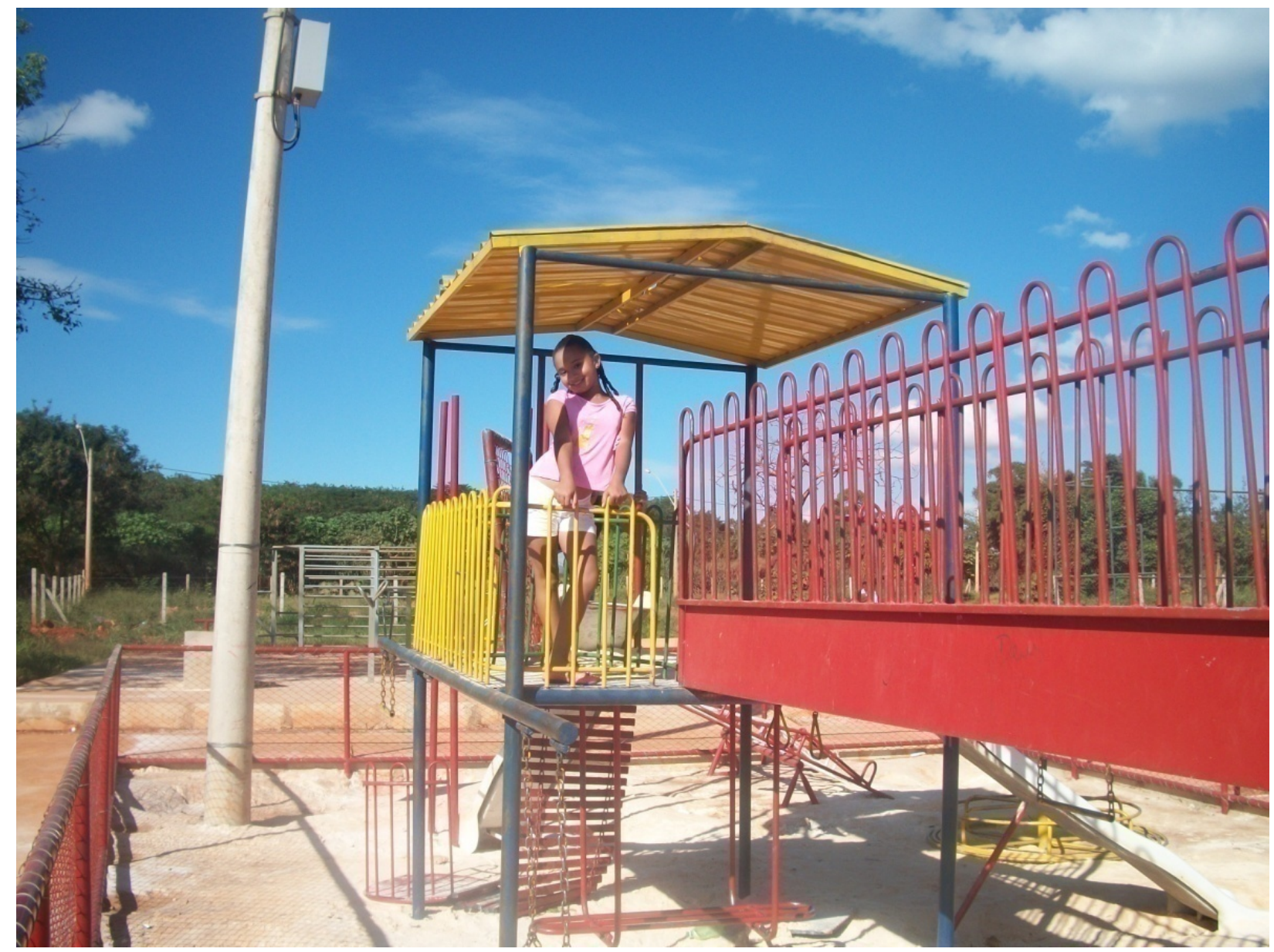

Ilustração 10 - Fran.Criança livre. Imagem fotográfica, 08 de maio de 2012

As crianças reforçaram o que Fran sinalizou destacando os momentos de felicidade, alegria oportunidade de uma criança se divertir no parque que também expõe uma paisagem com áreas verdes.

Assim, as crianças sugerem a necessidade de se incorporar, nos planejamentos urbanos, a destinação de espaços com estruturas apropriadas, considerando, nos aspectos paisagísticos, a presença de áreas verdes para diversão, bem como, nas práticas pedagógicas, sugerem momentos de interação 
por meio da brincadeira. Nessa perspectiva também apontam a necessidade da comunidade acompanhar a implementação das políticas públicas na localidade e garantir o acesso a serviços e equipamentos públicos como forma de se garantir justiça.

Ademais, pelas imagens selecionadas pelas crianças podemos destacar que não é só responsabilidade do Estado a criação e a manutenção de espaços de convivência com áreas verdes, pois, nas próximas fotos, Yohaninha e Bia valorizaram as iniciativas de famílias de colocarem plantas em suas casas.

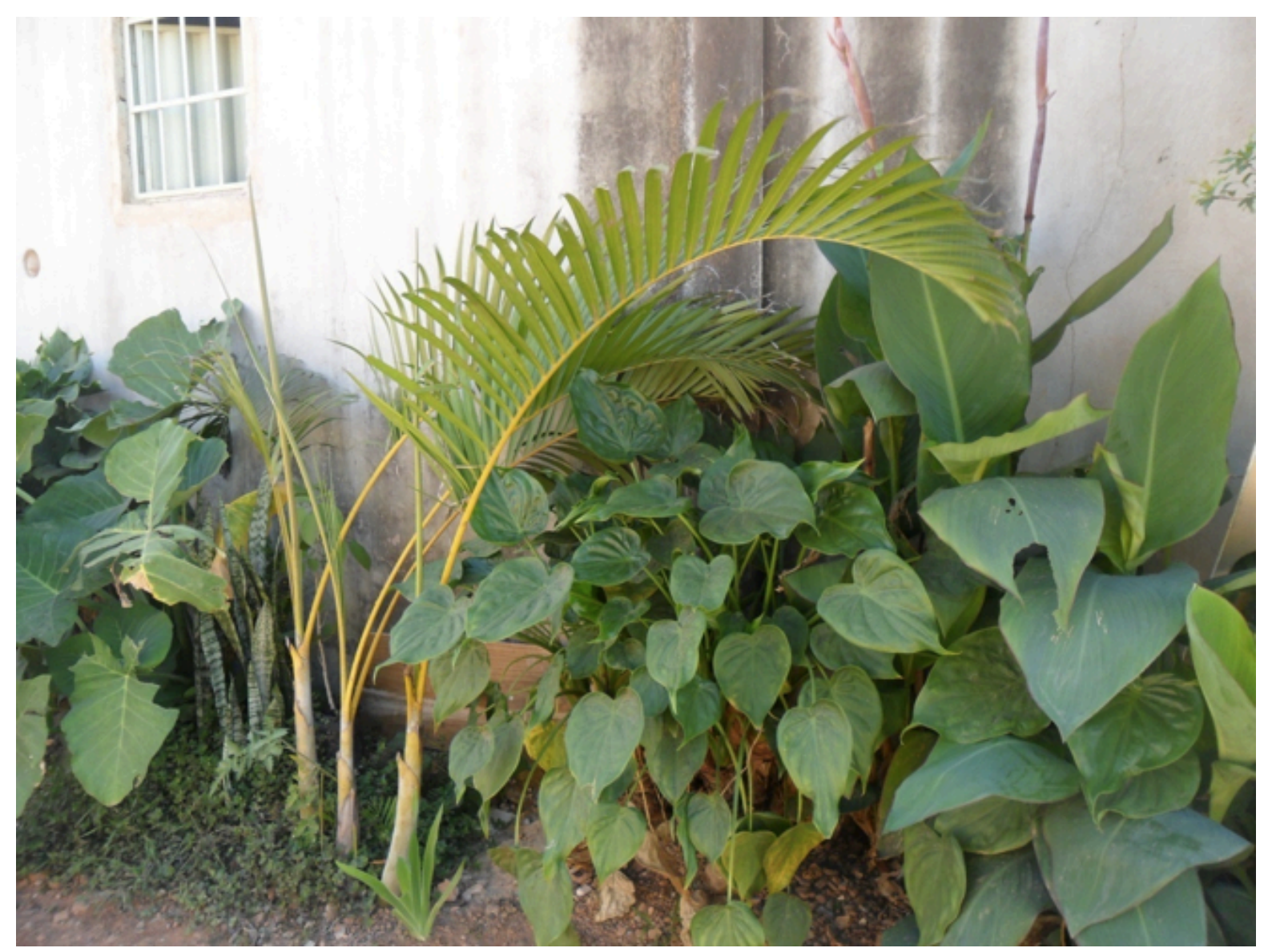

llustração 11 - Yohanninha.Folhas verdes. Imagem fotográfica, 08 de maio de 2012

A foto acima, realizada por Yohaninha, foi tirada da porta da casa de Fran. Nela várias folhagens diferentes (como espada de São Jorge, lírio da paz, copo de leite, dentre outras) cobrem o muro da casa, ocupando um pequeno espaço da calçada. 
O pai de Fran é jardineiro e mantém um lindo pequeno jardim na porta de sua casa. Yohaninha destaca que, em sua rua, não há iniciativas como essa, mas que gostaria que tivesse.

A foto de Bia é significativa para ilustrar as bases do desejo de Yohaninha.

Toda vez que Bia passa na frente da casa onde há a roseira, se sente feliz e alegre.



Ilustração 12- Bia. Flor Rosa. Imagem fotográfica, 03 de maio de 2012

Nesse caso a planta "muito bonita", de acordo com Bia, se destaca florida, tendo o rosa contrastando com o azul do céu. A flor, segundo Fran, "deixa a primavera mais bonita".As plantas nos espaços, dessa forma, abririam caminhos para uma nova forma de estar e conviver ligada a vínculos afetivos de interação e cuidado. 
Podemos indicar que para as crianças a ocupação do local prescinde de manutenção de áreas verdes, próximas às moradias, como também indica Cassi que seleciona uma foto em que a casa esta cheia de plantas com flores.

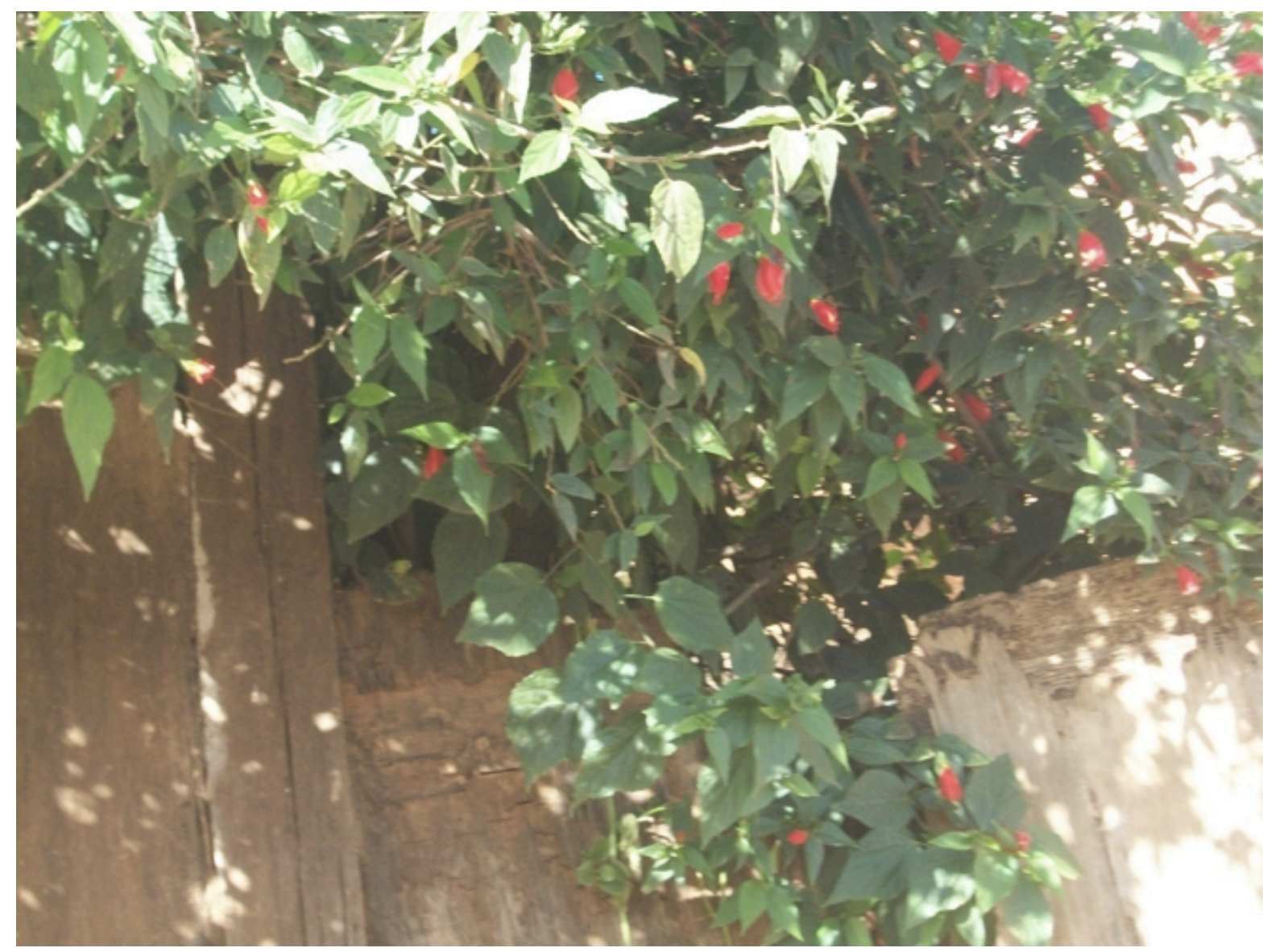

Ilustração 13 - Cassi. Plantas no chão. Imagem fotográfica, 03 de maio de 2012

Cassi ao fotografar o muro de madeira da casa coberto de plantas floridas, ressignifica aquela imagem ao relembrar das casas no estado do Pará, que vivia e brincava antes de chegar no Distrito Federal. Nesse caso, o muro que representa dificuldade de acesso para um local privado abre caminhos para o reencontro memórias de familiares íntimos e aproxima dos locais tão distantes e tão socioeconômicos e ambientalmente diferentes, como o Distrito Federal e o Pará.

A aproximação de locais também é sinalizada pelo destaque dado pelo próximo tema como veremos. 


\subsection{Mobilidade , infra-estrutura e resíduos sólidos}

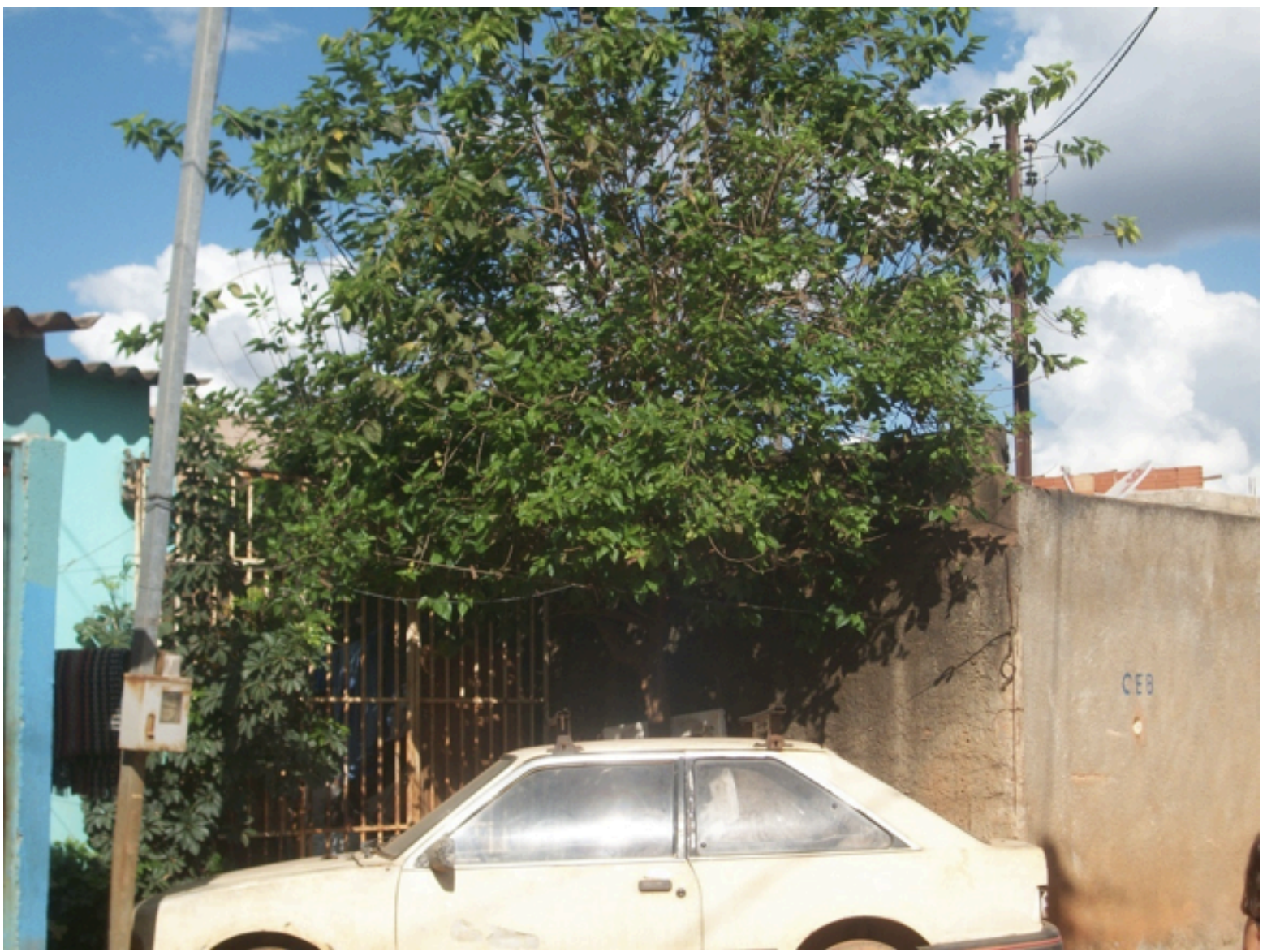

llustração 14 - Cassi. Corrida. Imagem fotográfica, 03 de maio de 2012

Cassi selecionou a foto abaixo por combinar alguns elementos importantes para ela: a casa, a árvore e o carro. A casa, pela moradia oportunizada, a árvore, por tornar o ambiente agradável e o carro, por ter a cor branca, sua segunda cor preferida, e também por permitir que as pessoas se desloquem com facilidade, permitindo viver a cidade com mais qualidade e até viajar para outras cidades de outros estados.

As crianças ao lerem a foto destacam que andar a pé por algumas ruas da Cidade Estrutural é muito ruim: quando em época de seca há muita terra e quando em época de chuva há muita lama. Ademais, o lixo fica acumulado em algumas ruas, atrapalhando também os pedestres. 
A foto abaixo destaca isso. Quando Cassi a selecionou, pensou que a parte em vermelho era a terra do chão e, só depois de vê-la impressa, viu que era o próprio dedo em frente à câmera.

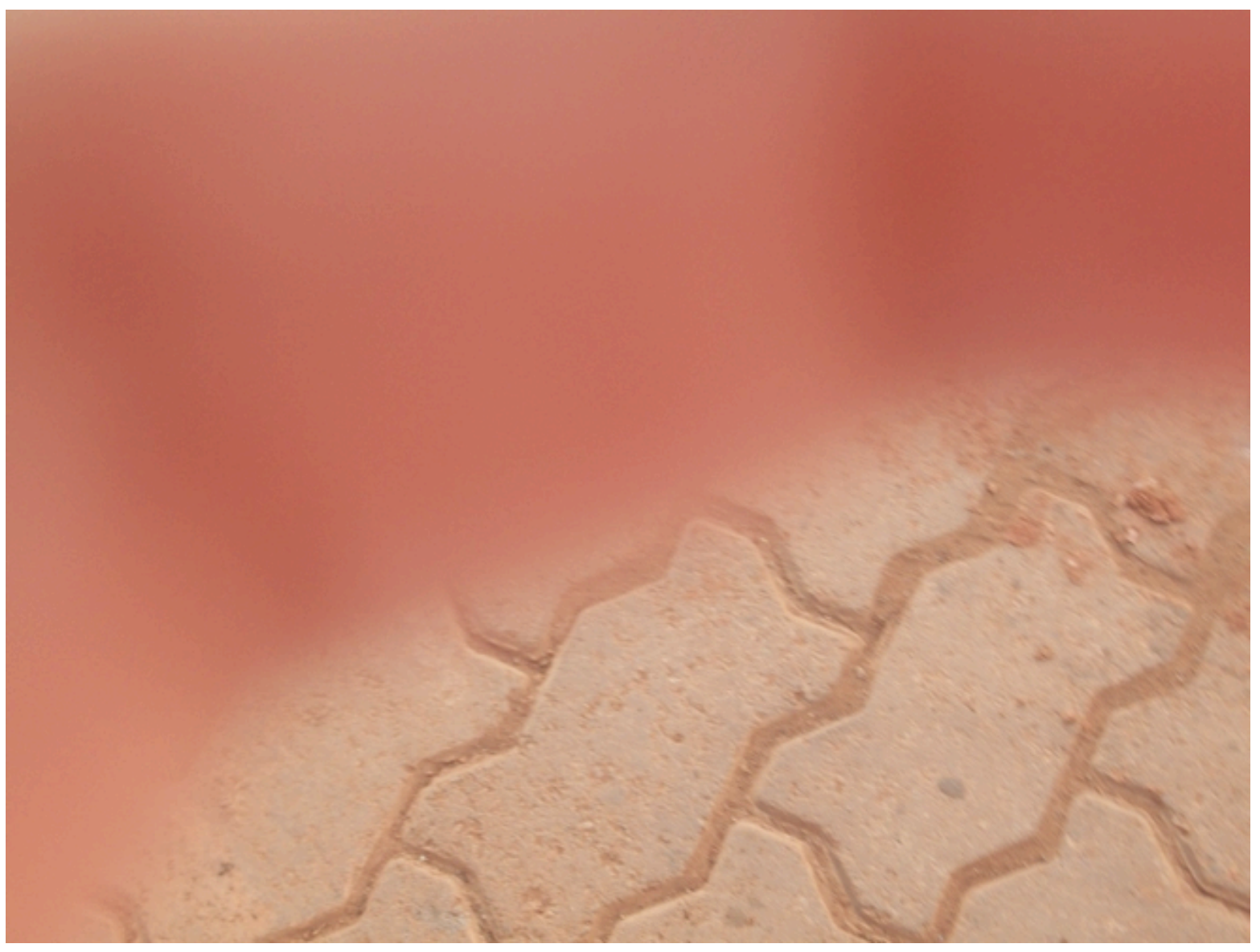

Ilustração 15 - Cassi. Chão vermelho. Imagem fotográfica, 03 de maio de 2012

As crianças aproveitaram para brincar com o fato: "pode falar que você mostrou dedo para câmera", disse Pedro. De fato, esta foto registra um descontentamento com a condição das ruas, pois muitos deles já quase perderam chinelos e caíram ao andar pela lama na rua e, em época de seca, ficaram com os pés todos sujos de terra.

A situação ainda fica pior, porque, em meio à terra, há também muito lixo nas ruas. Fran nos relatou que em todas as ruas pelas quais passa sempre encontra lixo. Pedro fica com raiva diante da situação, que eles caracterizam 
como cerceamento ou ausência de direitos de andar pela cidade e estar em um lugar limpo.

Nesse caso, o governo não dá o direcionamento apropriado ao lixo e as próprias pessoas não contribuem: jogam lixo por todos os lugares. Para as crianças, este lixo além de deixar a paisagem feia, prejudica as próprias pessoas que se veem obrigadas a circular pela cidade em meio à sujeira.

Vejamos as fotos abaixo:

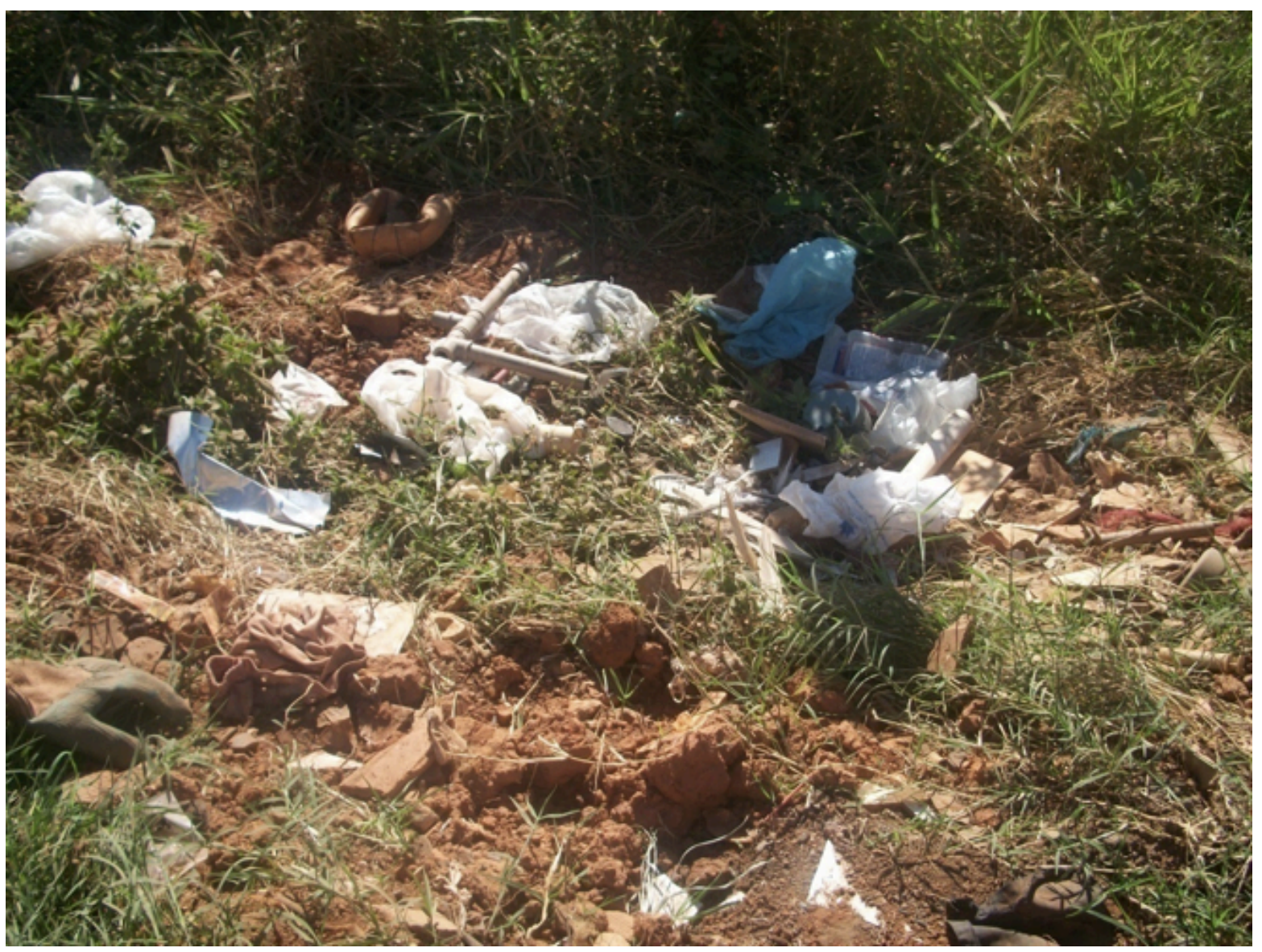

Ilustração 16 - Fran. Lixo ruim na rua. Imagem fotográfica, 08 de maio de 2012 


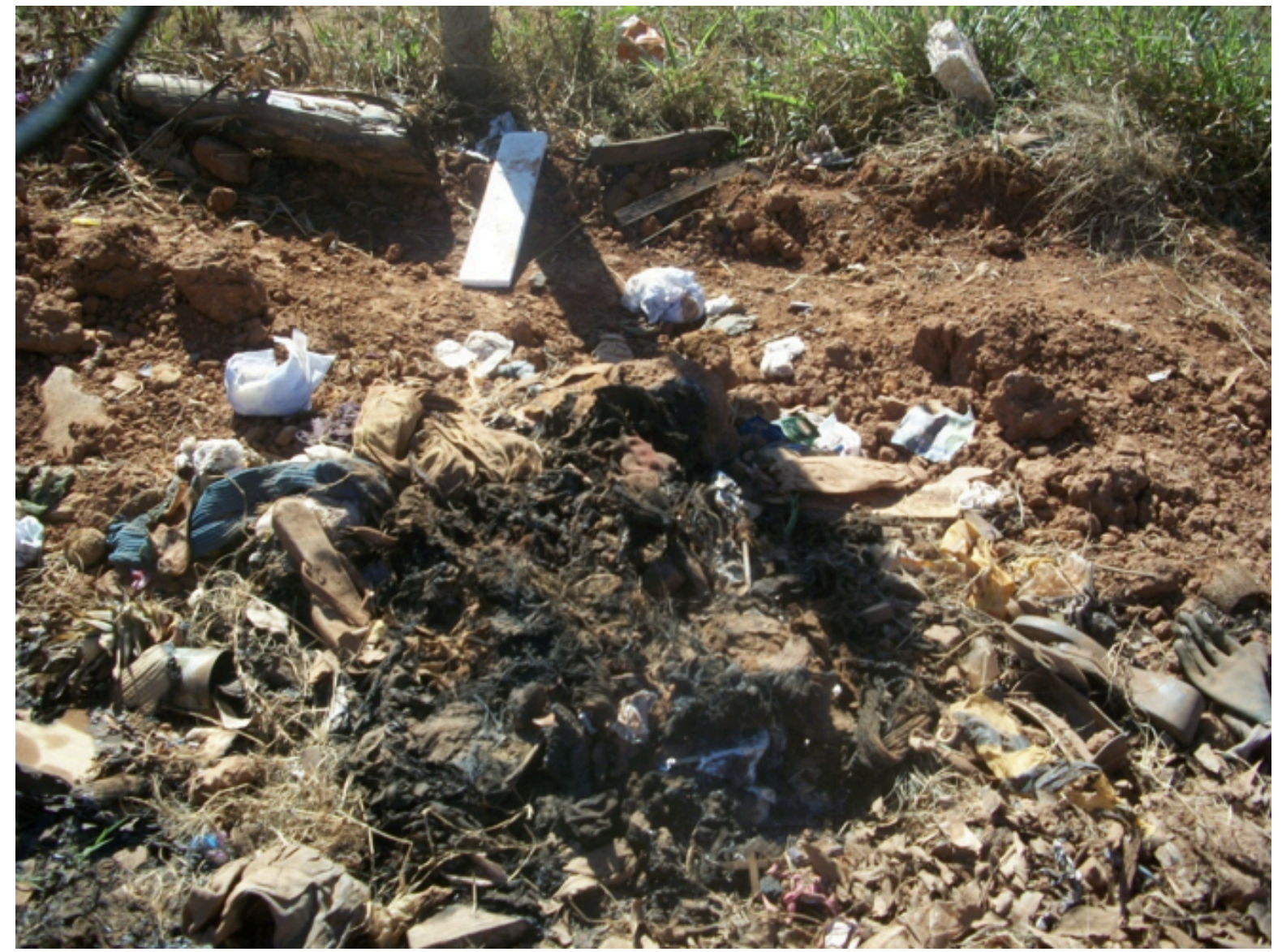

Ilustração 17 - Pedro. Lixão. Imagem fotográfica, 08 de maio de 2012 


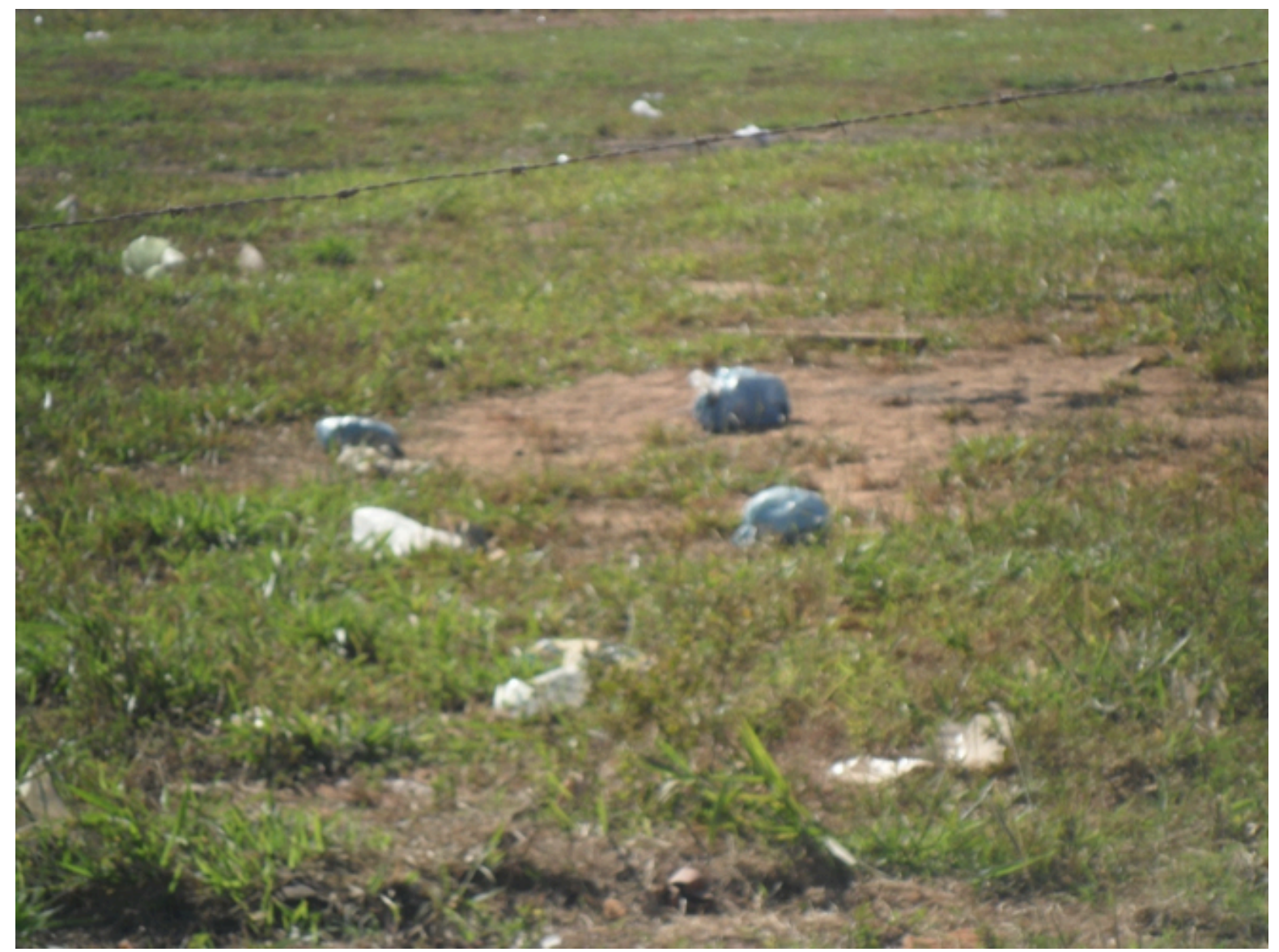

Ilustração 18 - Yohanninha. Lixo no campinho. Imagem fotográfica, 08 de maio de 2012

Como se pode perceber nas imagens acima, diferentes tipos de materiais podem ser encontrados em vários lugares da cidade. Ainda que a foto de Pedro seja intitulada Lixão, ela não foi tirada no local onde é depositado o lixo do DF; foi tirada em uma das ruas a caminho das "casinhas". Podemos perceber que, embora muitas famílias não tenham sua renda derivada da coleta de recicláveis, o lixo (que, da forma como é destinado, contém recicláveis e não recicláveis) ainda participa da vida das pessoas.

No texto Saindo pela Rua, elaborado coletivamente a partir das leituras das fotografias em uma atividade (durante o encontro 7), é possível perceber o quanto ele faz dialogar vários aspectos da vida na Cidade Estrutural. Segue abaixo o texto na íntegra: 
Saindo pela rua da cidade estrutural vi muitas pessoas, também vi lixo. Encontrei meus amigos e primos para ir brincar tipo a Carol, Monique, Bruna, Lucinara, tifani, Angélica, Roberta, Gabriel, Kenedy, João Vitor, Ramon, Tainara e Sâmara.

Hoje também fui para casa da minha tia.

Eu gostei. Mas ao andar pelas ruas lá perto das casinhas, tropecei no lixo.

Então, isso não pode ser assim,

Não se pode deixar o lixo no chão.

Eu vi um bocado de lixo na rua.

Lugar de lixo é na lixeira!

Ou no lixão?

Lá no lixão não é um lugar legal para se jogar lixo

Já basta o lixo que tem lá

Se não tiver mais lixão, e quem lá trabalha?

Cata latinha ue!

No lixo? Na lixeira? Ou na rua?

Mas com luvas

Ou arruma outro emprego

Mas é difícil arrumar emprego

O texto mostra a narrativa de uma criança sobre o que vivenciou em um dia, ao percorrer a cidade bem como destaca aspectos do processo histórico de consolidação da cidade.

Como dos 25. 732 habitantes das Cidade Estrutural 35,2\% são crianças de até 14 anos (PDAD, 2011), o fato de a criança da história encontrar muitos de seus colegas e possíveis familiares ilustra a caracterização da população, composta, em grande parte, por crianças e por pessoas que vieram para a cidade pora acompanhar parentes. A pesquisa revela que grande parte das 13.493 pessoas que lá chegaram de outros estados foram motivadas pela procura de trabalho $(44,8 \%)$ ou por acompanhar parentes (52,2\%). Em 2011, o número de pessoas desempregadas era 1.350; sem atividade era 715 , ao passo que 9.196 tinham trabalho remunerado (PDAD, 2011).

O lixo apontado anteriormente nas fotografas como problema, por poluir o ambiente, também é destacado como oportunidade para quem do lixo retira materiais recicláveis como forma de auferir renda e estabelecer uma nova forma de inclusão. Só que essa oportunidade esta sendo desafiada pelos limites em termos de espaço para destinação dos resíduos e impactos ambientais em virtude da forma como que o lixo é armazenado, e o texto já indica a 
preocupação com as famílas que tem como fonte de renda, o que é vendido com a coleta de recicláveis. 


\section{CONSIDERAÇÕES FINAIS}

A partir da leitura das fotografias, percebemos na narrativa construída uma abordagem complexa das questões socioambientais, apresentadas interrelacionada à uma construção específica de interação com ambiente e visão de natureza-sociedade, em consonância com as bases da formação em educação ambiental e assim, com o paradigma do saber ambiental. A narrativa dialogou com o contexto da vida das crianças, em especial do processo de desenvolvimento e construção da percepção e vivências na perspectiva de garantia de seus direitos.

A complexidade se debruça "na compreensão socio-ambiental da realidade" (VIEGAS, 2005, p.73) rompendo com o paradigma cartesiano, linear e interpretando-a e interrelacionando-a com elementos da sociedade e da natureza.

A abordagem complexa se revelou uma vez que as crianças, ao apontarem motivações para o registro e descreverem as imagens, destacavam sentimentos, situações e interrelacionavam os temas por meio de uma abordagem integradora aproximando a perspectiva de sociedade e natureza. Por exemplo, podemos perceber que o que era apresentado como ruim, de alguma forma era mitigado por aquilo que mostravam como bom ou de forma livre, como o que foi colocado por Cassi em Chão Vermelho e em Corrida, fotografias que retratam a mobilidade na Cidade Estrutural.

Se um campinho com áreas verdes era valorizado,em uma das imagens selecionadas,em outra, a presença do lixo o tornava ruim, desnecessário. Se as áreas verdes e de lazer eram valorizadas, elas também eram colocadas como ameaçadas pelo processo de ocupação.Também se o hábito de plantar folhagens em áreas públicas era destacado, o hábito de jogar lixo no chão também era, revelando, assim algumas contradições, possibilidades e limitações.

Ao longo da narrativa a percepção do ambiente estava baseada no contexto histórico de ocupação do espaço, nos significados atribuídos aos 
espaços e as formas de ocupação e gestão, nas características físicas de conformação do local e elementos psicossociais como vínculos afetivos vinculados a interação com o ambiente e seleção de imagens em consonância com o que Kuhnen (2011) destaca sobre o processo perceptivo.

Do que foi possível registrar no passeio pela cidade realizado, ao se caminhar a pé pelas ruas da região de moradia das crianças, as questões relacionadas aos temas convivência familiar e comunitária, lazer, áreas verdes, infraestrutura, mobilidade e resíduos sólidos se destacaram.

Ademais, os temas eram colocados de forma interconectada - como se pode ver no texto Saindo pela rua e nas fotos Criança na árvore, Dentro do mato - em uma rede complexa de relações e acontecimentos imbricados na dinâmica de interação do ambiente e nas consequências da ocupação do mesmo, sinalizando o que as intervenções "vem rompendo a capacidade de suporte desse ambiente se auto-equilibrar através de sua dinâmica natural"( GUIMARÃES, 2006, p.16).

Assim no processo de construção da narrativa, ao longo da oficina, desempenhamos uma prática educativa ambiental:

“ que vai muito além da aquisição de informações, sensibilização, explicação causal de fenômenos e mudança de comportamentos. É praxis, problematização e atuação transformadora da sociedade" ( Loreiro, 2006, p.132)

Conhecer a representação das crianças no âmbito de sua percepção contribuiu para reflexão, produção de novos conhecimentos e se revelou importante no trabalho educativo. De acordo com Veiga (2005, p.74) "a tentativa de compreendermos um mundo complexo é uma permanente superação da nossa capacidade de entender o mundo". Nesse sentido a compreensão da realidade provoca a apreensão de novos elementos que fazem com que um novo real se estabeleça de acordo com o enfoque dado. 
Sendo assim, ao revelar uma narrativa que traz como basilar elementos relacionados à convivência familiar e comunitária e lazer, a percepção das crianças sobre as questões sociambientais além de reiterar a perspectiva trazida na proposta de proteção integral normatizada ECA da qual traz destaque para efetivação de direitos em alguns campos, também sinaliza a necessidade de efetivação de direitos relacionados à outros campos como os relacionados à questões de infra-estrutura mobilidade e resíduos sólidos, não explicitadas no ECA. Isso sugere a existência de temas específicos dos quais as crianças, dariam mais ênfase, que poderiam ser considerados na formulação e execução de políticas sociais voltadas para proteção da criança e adolescente e integrados à outras normatizações como o Estatuto das Cidades.

Em relação às questões socioambientais, com a leitura das fotografias, também podemos identificar a construção de uma narrativa que reforça a perspectiva apontada no estudo de Higuchi (2008) sobre a forma de compreensão da noção do espaço das cidades vividos pelas crianças interrelacionada ao processo de desenvolvimento da percepção, tendo o núcleo familiar, para crianças na idade das que participaram da pesquisa, como central para constituição da representação dos espaços. Isso pode ser observado uma vez que no passeio pela cidade, percorremos prioritariamente as ruas próximas as suas residências e as crianças selecionaram momentos de convivências familiar como elementos positivos e livres da vivência pela cidade. Tal perspectiva foi considerada no trabalho educativo realizado.

Nesse caso, aspectos das imagens mentais criadas pelas crianças foram desvelados como parte de um processo de confrontação de indícios com ideias anteriormente criadas e recordações das pessoas do grupo. Como vimos, na interação social, a partir da experiência sensório-motora e mediante o processo perceptual, as imagens mentais são criadas, contribuindo, assim, para a apreensão da realidade e para o estabelecimento de relações substanciais que acabam por ser ícones simbólicos, impregnados de significação (FISCHER,1994; KUHNEN, 2011) Assim, a medida que íamos produzindo as imagens e analisando-as, reorganizávamos nosso esquema de referências do lugar de 
moradia das crianças e discutíamos as questões socioambientais na perspectiva de formação de sujeitos ecológicos.

No decorrer da oficina, o grupo foi se formando e se conhecendo um espaço de diálogo e respeito foi criado enquanto os conteúdos foram trabalhados. Mas como este trabalho não tinha como objeto de reflexão o processo pedagógico, algumas situações ocorridas não foram estudadas. Sugere-se que a interface do uso de fotografias em ações educativas sejam aprofundadas em outros estudos, bem como a articulação do estudo e aprendizado dos conteúdos dos componentes curriculares com as atividades desenvolvidas na oficina.

Do que foi investigado, podemos apontar que desenvolvemos um processo de educação ambiental envolvendo a conscientização das crianças em relação aos processos de garantias de direitos, afirmando a infância enquanto tempo de direitos e destacando-as como sujeitos destes direitos, contribuindo, assim para reafirmar o compromisso social pactuado na promulgação das legislações e fortalecendo os processos para a gestão urbana.

Para a efetivação do processo de garantia de direitos ainda é necessário articular o trabalho pedagógico desenvolvido a processos de mobilização social, envolvendo outros atores estratégicos. Tais processos podem se realizar por meio de programas, projetos e eventos culturais de forma a dar continuidade ao trabalho realizado. Não tivemos a oportunidade no decorrer da pesquisa de envolver a comunidade e trabalhar as questões apresentadas de forma ampla, sendo assim sugere-se que, a partir deste trabalho, sejam desenvolvidos instrumentos para envolver mais sujeitos, tanto familiares quanto membros das comunidades e maior número de crianças, pois outros aspectos que não se apresentavam enquanto objetivo de investigação acerca do mundo da criança poderão se mostrar evidentes, como a influência do contexto sócio-histórico na vida das crianças que lá moram e a inter-relação delas com outras pessoas da comunidade. 


\section{REFERÊNCIAS}

ABRAMOVAY, M. Violência nas escolas. Brasília: UNESCO, 2002.

ACSELRAD, H.; HERCULANO, S; Pádua. J. A. (Orgs.). Justiça ambiental e cidadania. Rio de Janeiro: Relume Dumará, 2004.

ACSERALD, H. Discursos da sustentabilidade urbana. Revista Brasileira de Estudos Urbanos e Regionais, Campinas, n.1, p. 79-90, maio. 1999.

ARROYO, M G. Educação de jovens-adultos: um campo de direitos e de responsabilidade pública. In: SOARES, L; GIOVANETTI, M.A. G. C.; GOMES, N. L (orgs.). Diálogos na educação de jovens e adultos. Belo Horizonte: Autêntica, 2005. p. 19- 50.

BAITELO JÚNIOR, Norval. A era da iconofagia. São Paulo: Hacker Editores, 2005.

BRASIL. Lei n. 10.257 de 19 de julho de 2001 - Estatuto da Cidade. Regulamenta os arts. 182 e 183 da Constituição Federal, estabelece diretrizes gerais da política urbana e dá outras providências. Disponível em:

$<$ http://www.planalto.gov.br/ccivil_03/leis/LEIS_2001/L10257.htm.> Acesso em: 02 de março de 2012.

CAVAlCANTE, S; NOBREGA, L. M. A. Espaço e lugar. In: CAVALCANTE, S; ELALI, G. A. Temas Básicos em psicologia ambiental. Petrópolis: Vozes. p. 182-190.

CARVALHO, Isabel Cristina Moura. Educação ambiental: a formação do sujeito ecológico. São Paulo: Cortez, 2008.

.Educação Ambiental Crítica: nomes e endereçamentos da educação. In: Philippe Pomier Layrargues.Identidades da Educação Ambiental no Brasil.Brasília, Ministério do Meio ambiente. 2004,

CODEPLAN, Companhia de planejamento do DF. Retrato da Infância e da Adolescência do Distrito federal. 2012. Disponível em: <http://www.codeplan.df.gov.br> Acesso em:02/06/2012.

CORRÊA, Kátia Simone Marscicano. A ocupação urbana no entorno de unidade de conservação: omissão, descaso ou oportunismo? O caso da invasão da Estrutural no entorno do Parque Nacional de Brasília. 2002. 189f. Dissertação (Mestrado em Planejamento e Gestão Ambiental) Universidade Católica de Brasília, Brasília, 2002.

COSTA, Cláudia Moraes da. Reciclagem e cidadania: a trajetória de vida dos catadores de material reciclável da comunidade reciclo. 2008. 168f. Dissertação (Mestrado em Educação). Universidade de Brasília, Brasília, 2008.

COSTA, T. S. O. Participação Cidadã. Poder de conquista ou negação? 2011. 84f. Trabalho de Conclusão de Curso (Graduação em Pedagogia). Universidade de Brasília, Brasília, 2011. 
DEL RIO, V.; OLIVEIRA, L. (Orgs.). Percepção Ambiental: a experiência brasileira. São Carlos : Editora da UFSCar, 1996

DISTRITO FEDERAL. Estudo de Impacto Ambiental/Relatório de Impacto Ambiental.

Brasília: Terracap, 2004. 430p.

DISTRITO FEDERAL. Programa Brasília Sustentável. Relatório de Avaliação Ambiental. Brasília: Adasa, 2005.

DISTRITO FEDERAL. Pesquisa Distrital por Amostra de Domicílios - Scia - Estrutural 2011. Brasília: Codeplan, 2011. Disponível em: <http://www.codeplan.br $>$ Acesso em: $02 / 06 / 2012$.

DISTRITO FEDERAL. Diagnóstico do desenvolvimento social do Distrito Federal. Brasília, Sedest. Disponível em <http://www.sedest.df.gov.br> Acesso em: 02/06/2012.

DOSSIÊ DAS PRINCIPAIS DENÚNCIAS DO FÓRUM DE MONITORAMENTO DO PROGRAMA BRASÍLIA SUSTENTÁVEL NA CIDADE ESTRUTURAL, BRASÍLIA-DF. Disponível em: http://forumestrutural.blogspot.com/ Acesso em 12/06/2012.

FEDERAL, G. ESTATUTO DA CRIANCA E DO ADOLESCENTE, lei federal 8069/1990. 6 ed. 20 anos do ECA, 2010. Disponível em: <http:// www.sedh.gov.br $>$ Acesso em:17/03/2012.

FEDERAL, G. ESTATUTO DAS CIDADES Lei federal no 10257 de 2001 Disponível em: $<$ http://www2.camara.gov.br/legin/fed/lei/2001/lei-10257-10-julho-2001-327901-norma-pl.html> Data de acesso 17/03/2012.

FISCHER, G. Psicologia Social do Ambiente. Lisboa: Instituto Piaget.1994.

FREIRE, P. Educação como prática de liberdade. Rio de Janeiro: Paz e Terra, 1967.

FREIRE, P. Pedagogia do oprimido. Rio de Janeiro: Paz e Terra, 1988.

GADOTTI, Moacir. Educação e Poder: introdução à pedagogia do conflito. São Paulo, Cortez Autores Associados, 1981.

Pedagogia da Terra. São Paulo, Fundação Peirópolis, 2000.

GUIMARÃES, Mauro. Educação ambiental crítica. In: Philippe Pomier Layrargues.Identidades da Educação Ambiental no Brasil. Brasília, Ministério do Meio ambiente. 2004. p. 25-34

HIGUCHI, M. I. G. Making sense of dwelling Place: a study among urban amazonian children. Médio Ambiente y Comportamento Humano - An International Environmental Psycology Reviw, vol 9, n 1-2, p. 149-170, 2008. 
HIGUCHI, M. I. G.; KUHNEN, A. Percepção e representação ambiental- Métodos e técnicas de investigação para Educação Ambiental. In: PINHEIRO, J. G; GUNTHER, H. (Orgs.). Métodos e técnicas de pesquisa pessoa-ambiente. São Paulo: Casa do psicólogo, 2008. p. 181-215

HIGUCHI, M. I. G.; KUHNEN, A ; BONFIM, Z. A. C. Cognição Ambiental. In: CAVALCANTE, S; ELALI, G. A. Temas Básicos em psicologia ambiental. Petrópolis: Vozes, 2011. p. 105-121.

HUMBERTO,L. Fotografia, a poética do banal. São Paulo: Imprensa Oficial do Estado,2000.

KOSSOY, B. Realidades e fiç̧̃̃es na trama fotográfica. Cotia: Ateliê Editorial, 2002.

KOSSOY, B. Fotografia e História. 3. ed. rev. e ampl..São Paulo: Ateliê Editorial, 2009.

KUHNEN, A. Percepção ambiental. In: CAVALCANTE, S.; ELALI, G. A. Temas Básicos em psicologia ambiental. Rio de Janeiro: Petrópolis,Vozes, 2011.p250-222.

KUHNEN, A. HIGUCHI, M. I. G. Campos de encontro da psicologia e educação na construção de comportamentos socioambientais. Utopia y Práxis Latinoamericana, ano 14, n. 44, p. 101108, 2009.

LAYRAGUES, P. P. Educação ambiental como compromisso social: o desafio da superação das desigualdades. In: LOUREIRO, C. F. B.; LAYRAGUES, P. P.; CASTRO, R. S. (Orgs.). Repensar a Educação Ambiental: um olhar crítico. São Paulo: Cortez, 2009. p 11-32

LOUREIRO, C.F.B. Teoria crítica. In AMBIENTE, M.M Encontros e caminhos: formação de educadoras( es) ambientais e coletivos educadores.Brasília: 2005

. Problematizando conceitos in LOUREIRO,C.F,B ; LAYRAGUES, P. P. Pensamento complexo, dialética e educação ambiental. São Paulo: Cortez, 2006.

LYNCH, A. A imagem da cidade. São Paulo: Martins Fontes, 1980.

Some Childhood memories of the city (1956). In LYNCH, K; BANERJEE, T.; SOUTHUWORTH, M. City sense and city design: writings and projects of Kevin Lynch. Cambridge, Mass: MIT Press, 1995.

LOPES, José Sérgio Lopes (Coord.). A Ambientalização dos conflitos sociais. Rio de Janeiro: Relume Dumará, 2004.

LURIA, A. R. Curso de Psicologia Geral. vol 2. Rio de Janeiro: Civilização Brasileira, 1979. 
LUDKE, M.; MARLI, E. D. A pesquisa em educação: abordagens qualitativas. São Paulo: EPU, 1986.

NUNES, A.O Como restaurar a paz nas Escolas. São Paulo. Contexto 2011

MARIN, A. A. Pesquisa em Educação Ambiental e percepção ambiental. Pesquisa em

Educação Ambiental, vol 3, n. 1, p. 2003-222, 2008.

Morin,E. . Introdução ao pensamento complexo. Porto Alegre: Sulina 3.ed. 2007

MUCHOW, M. \& MUCHOW, H. H. The life space of urban child .1936/1978 data do original em Alemão. Tradução de Hartmurt Gunther ( texto não publicado) .

PIAGET, J. Seis estudos sobre psicologia. Rio de Janeiro: Forense, 1978.

PIAGET, J.; INHELDER, B.The child`s conception of Space. Londres: Routhedge \& Kegan Paul, 1967.

PROJETO DOCES MATAS. Brincando e aprendendo com a mata: manual para excursões guiadas. Belo Horizonte, 2002.

SIMON, R. Ficções e poéticas imagéticas: fotografia de projetos socioculturais. 2010. $117 \mathrm{f}$.

Dissertação (Mestrado em Comunicação). Universidade de Brasília. Brasília, 2010

THEODORO, S. H. (Org.). Mediação de conflitos socioambientais. Rio de Janeiro: Garamond, 2005.

VIÉGA, A. Complexidade. In AMBIENTE, M.M Encontros e caminhos: formação de educadoras( es) ambientais e coletivos educadores.Brasília: 2005

ZANETI, Isabel. Inclusão social, resíduos sólidos e reciclagem. Uma ação transdiciplinar em busca da sustentabilidade. CONGRESSO MUNDIAL DE TRANSDICIPLINARIDADE, 2, cidade. Anais... Vitória, 2005. 


\title{
APÊNDICE A - Autorização da Entidade
}

Solicitação de Pesquisa

Autorizamos Fernanda Fagundes Alves, aluna de Mestrado em Educação da Universidade de Brasília-UNB realizar pesquisa ao desenvolver a Oficina Imagens da cidade, fotografando o ambiente, sob orientação de Cláudia Pato, professora do programa de Pós-Graduação da UnB.

Para a realização da atividade, o Coletivo da Cidade irá ceder o espaço e disponibilizar dados das fichas de cadastro das crianças pertinentes à pesquisa, que serão tratados e analisados de forma ética conforme previsto no Estatuto da Criança e Adolescente - ECA. A pesquisadora irá providenciar todo o material necessário para o desenvolvimento da atividade.

Participarão da pesquisa crianças atendidas pelo Coletivo da Cidade que manifestaram interesse em compartilhar da Oficina e que tenham autorização dos pais.

Informamos que o projeto de pesquisa e o planejamento da oficina foi analisado, estando em conformidade com a proposta pedagógica da entidade.

Atenciosamente,

\author{
Coordenação Colegiada do Coletivo da Cidade
}




\section{APÊNDICE B - Carta aos responsáveis legais}

Sr(a)s responsáveis,

No Coletivo da Cidade será realizada a oficina Imagens da cidade, fotografando o ambiente, como parte da pesquisa realizada por Fernanda Fagundes Alves, sob orientação da professora Dra. Claudia Pato, para o mestrado em Educação da Universidade de Brasília-UnB.

O objetivo da pesquisa é compreender as imagens que as crianças que residem na Cidade Estrutural têm sobre o lugar onde moram.

As crianças participantes terão a oportunidade de explorar a fotografia com o uso de máquinas fotográficas fornecidas pelo projeto, para contarem um pouco sobre como percebem a cidade em que vivem.

Para tanto, estão previstos dois encontros no Coletivo da Cidade, em que as crianças participarão de rodas de diálogos e jogos, para os quais serão orientadas a fazerem registros fotográficos. Além disso, será feito um passeio a pé pela cidade, em especial pela quadra próxima à residência da criança, em data e horário a ser combinado com o senhor(a), para facilitar o registro de aspectos familiares. O passeio será realizado com a companhia da responsável pela atividade. Todas as atividades serão gravadas e os resultados de todo o processo, após análise e interpretação, serão usados na pesquisa e divulgados de acordo com princípios éticos e de responsabilidade.

Essa atividade poderá contribuir para desenvolvimento de material pedagógico, capacitação de profissionais da educação e novos trabalhos e atividades a serem realizados na Estrutural em momento posterior.

manifestou interesse e foi sorteado(a)para participar da oficina

de fotografia. Por isso estamos entrando em contato com o(a ) senhor( a) para pedir sua autorização. Somente com a sua autorização por escrito, ele(a) poderá participar dessa atividade. A autorização deverá ser preenchida e entregue no coletivo da Cidade até o dia maiores informações, estamos disponíveis no Coletivo da Cidade (contato com Jackeline). Desde já, agradecemos a sua colaboração e atenção.

Atenciosamente,

Fernanda Fagundes Alves

Matrícula 10-0044476 UNB-PPGE 


\section{APÊNDICE C - Autorização dos responsáveis legais}

Eu, responsável legal por autorizo a participação dele (a) na

oficina Imagens da cidade, fotografando o ambiente, que será realizada no Coletivo da Cidade no período de 25 de abril a 9 de maio, como parte das atividades de pesquisa realizada por Fernanda Fagundes Alves, sob orientação da Prof ${ }^{a}$ Dr $^{\mathrm{a}}$ Claudia Pato, da Universidade de Brasília.

Estou ciente dos objetivos e procedimentos, sobretudo que

fará um registro fotográfico pelas ruas da

cidade em uma data a ser combinada comigo, sob a companhia da pesquisadora, e também será entrevistado (a) para fins acadêmicos, conforme princípios de ética e responsabilidade, podendo o resultado ser divulgado para fins acadêmicos e pedagógicos.

Brasília, de de 2012.

Assinatura do Responsável 


\section{APENDICE D - Ficha de cadastro}

\section{Questionário numero}

Nome do aluno *

Nome a ser usado na pesquisa* ( nome a ser definido pelo próprio aluno em atividade na oficina)

Série escolar *

Responsável legal e contato

Endereço

Referências do endereço *

Vive na Cidade Estrutural a quanto tempo *

Forma com que se desloca escola -casa *

( ) a pé ( ) de carro ( )de bicicleta

( ) sozinho ( ) em companhia de responsável ( ) em outra companhia

Condições da residência do aluno*

$$
\text { - Condições de ocupação }
$$

( )posse ( ) proprietário ( ) aluguel ( ) lote regularizado

( ) invasão

- Destino dado aos dejetos de sua residência

( )Esgoto ( ) Fossa séptica ( ) Fossa seca ( ) céu aberto ( ) outro

1- Origem da água

( ) encanada ( ) vizinho ( )cacimba ( ) poço artesiano ( ) outro

Pessoas vinculadas ao núcleo familiar *

\section{2- Dados que poderão ser divulgados no trabalho final}




\section{APÊNDICE E - Roteiro de atividades}

\section{Encontro 1}

\begin{tabular}{|c|c|c|c|}
\hline $\begin{array}{l}\quad \text { ETAPA } \\
\text { No início, explica- se } \\
\text { aos participantes a } \\
\text { proposta desse primeiro } \\
\text { momento }\end{array}$ & $\begin{array}{c}\text { TEMPO } \\
2 \mathrm{~h}\end{array}$ & ATIVIDADE & MATERIAL \\
\hline \multirow{3}{*}{ Integração } & $20 \mathrm{~min}$. & $\begin{array}{l}\text { Elaboração de crachá: entregar } \\
\text { o crachá e solicitar que seja } \\
\text { escrito o nome de um lado e um } \\
\text { outro nome escolhido pela } \\
\text { pessoa para ser o nome artístico } \\
\text { a ser usado no trabalho. Ao } \\
\text { final, todos compartilham seus } \\
\text { nomes criados. } \\
\\
\text { mento importante para } \\
\text { integração do grupo. Uma } \\
\text { atividade usada tanto para que } \\
\text { os participantes se apresentem } \\
\text { quanto para identificar a forma } \\
\text { de referência a eles no âmbito } \\
\text { da pesquisa e aproveitar para } \\
\text { criar um ambiente para abertura } \\
\text { à comunicação e exposição de } \\
\text { ideias, valorizando a } \\
\text { experiência e proposta de cada } \\
\text { um. }\end{array}$ & $\begin{array}{l}\text { Cartolina cortada em } \\
\text { retângulos, barbante, } \\
\text { lápis de cor e/ou } \\
\text { canetinha. }\end{array}$ \\
\hline & & & \\
\hline & $8 \mathrm{~min}$. & $\begin{array}{l}\text { Olhar pela Moldura (adaptação } \\
\text { da atividade "O mundo de ponta } \\
\text { a cabeça", do Projeto Doces } \\
\text { Matas. Brincando e aprendendo } \\
\text { com a mata. Manual para } \\
\text { excursões guiadas. Belo } \\
\text { Horizonte, 2002): solicita-se aos } \\
\text { participantes que andem pelo } \\
\text { ambiente carregando uma } \\
\text { moldura pintada com papelão. } \\
\text { Quando o facilitador fala "foto", } \\
\text { todos experimentam olhar de } \\
\text { formas variadas através da } \\
\text { moldura, de acordo com os } \\
\text { comandos dados - 1) olhe para } \\
\text { frente; 2) incline a cabeça para } \\
\text { lado direito e para baixo e olhe; } \\
\text { 3) olhe para trás; 4) olhe entre } \\
\text { as pernas; 5) abaixe e olhe para }\end{array}$ & $\begin{array}{l}\text { Sala de aula, sem } \\
\text { cadeiras dispostas no } \\
\text { meio ou ambiente ao }\end{array}$ \\
\hline
\end{tabular}




\begin{tabular}{|c|c|c|c|}
\hline & & $\begin{array}{l}\text { o teto; 6) incline só a cabeça e } \\
\text { olhe para o lado esquerdo. } \\
\text { Após esse momento, reúna os } \\
\text { participantes e pergunte o que } \\
\text { viu, se era algo novo ou } \\
\text { diferente. } \\
\text { Obs: nesta atividade é possível } \\
\text { já abordar sobre o } \\
\text { enquadramento na fotografia e } \\
\text { as realidades fotográficas. Além } \\
\text { disso, trabalha-se com o grupo o } \\
\text { desvelamento do momento em } \\
\text { que o registro é feito e a } \\
\text { construção de narrativas. }\end{array}$ & $\begin{array}{l}\text { ar livre; retângulos } \\
\text { feitos com papelão } \\
\text { com dimensões } \\
15 \times 21 \mathrm{~cm} .\end{array}$ \\
\hline & $10 \mathrm{~min}$. & $\begin{array}{l}\text { Esclarecimentos sobre a } \\
\text { proposta da oficina: gravação, } \\
\text { período, vinculação com a } \\
\text { pesquisa, metodologia. } \\
\text { Elaboração coletiva das regras } \\
\text { de convivência no local. }\end{array}$ & \\
\hline Sensibilização & 15 min. & $\begin{array}{l}\text { Máquina e fotógrafo com } \\
\text { revelação (adaptação da } \\
\text { atividade "O mundo de ponta a } \\
\text { cabeça" do Projeto Doces } \\
\text { Matas. Brincando e aprendendo } \\
\text { com a mata. Manual para } \\
\text { excursões guiadas. Belo } \\
\text { Horizonte. 2002): solicita-se aos } \\
\text { participantes que se dividam em } \\
\text { duplas. Uma pessoa da dupla } \\
\text { passa a ser a máquina e a outra a } \\
\text { fotógrafa. A pessoa que } \\
\text { representa a máquina fecha os } \\
\text { olhos, a fotógrafa conduz a } \\
\text { "câmera" (segurando em seu } \\
\text { ombro). A fotógrafa procura } \\
\text { imagens interessantes, cuidando } \\
\text { bem da máquina que está em } \\
\text { suas mãos. Quando descobre } \\
\text { algo, dá um toque no ombro } \\
\text { direito da "câmera" que } \\
\text { imediatamente, abre os olhos, } \\
\text { fazendo o registro da imagem. } \\
\text { Depois inverte: quem era } \\
\text { máquina passa a ser fotógrafo e } \\
\text { quem era fotógrafo passa a ser } \\
\text { máquina. Em seguida, cada um } \\
\text { faz um desenho com giz branco } \\
\text { na folha de algo que tenha } \\
\text { registrado e depois revela, } \\
\text { passando a folha da vasilha com } \\
\text { água com anilina. Deixam-se as } \\
\text { folhas em um varal montado na } \\
\text { sala para secar e todos verem as }\end{array}$ & $\begin{array}{l}\text { Folha A4, anilina } \\
\text { colorida, forma de } \\
\text { bolo ou vasilha } \\
\text { grande retangular, } \\
\text { água, giz branco. }\end{array}$ \\
\hline
\end{tabular}




\begin{tabular}{|l|l|}
\hline & $\begin{array}{l}\text { imagens reveladas. } \\
\text { Para concluir, discutem-se os } \\
\text { desenhos, destacando as } \\
\text { diferenças de temas e de } \\
\text { elementos a eles vinculados, de } \\
\text { formas de representação. }\end{array}$ \\
& $\begin{array}{l}\text { Obs: nesta atividade pode-se } \\
\text { trabalhar a questão do cuidado } \\
\text { com o equipamento fotográfico, } \\
\text { despertar a confiança entre as } \\
\text { pessoas do grupo, as } \\
\text { particularidades das percepções } \\
\text { de cada um, o respeito ao } \\
\text { trabalho do colega. }\end{array}$ \\
\hline
\end{tabular}

\section{Encontro 2}

\begin{tabular}{|c|c|c|c|}
\hline ETAPA & $\begin{array}{c}\text { TEMPO } \\
2 \mathrm{~h} \\
\end{array}$ & ATIVIDADE & MATERIAL \\
\hline $\begin{array}{l}\text { Integração } \\
\qquad \text { Como preparação, o } \\
\text { mapa da cidade será } \\
\text { providenciado e o } \\
\text { percurso indicado na } \\
\text { ficha de inscrição será } \\
\text { ilustrado. }\end{array}$ & $5 \mathrm{~min}$. & $\begin{array}{l}\text { Caminhos do passeio: } \\
\text { apresenta-se o mapa da cidade, } \\
\text { identificam-se as principais } \\
\text { referências, confirma-se o } \\
\text { trajeto percorrido pela criança } \\
\text { de cada ao espaço educativo. } \\
\text { Nesta atividade procura-se } \\
\text { deixar que a criança se situe no } \\
\text { mapa; caso haja dificuldade, } \\
\text { auxiliam-se as crianças, } \\
\text { sugerindo lugares e caminhos. }\end{array}$ & $\begin{array}{l}\text { Mapa com as } \\
\text { referências das } \\
\text { moradias. }\end{array}$ \\
\hline
\end{tabular}




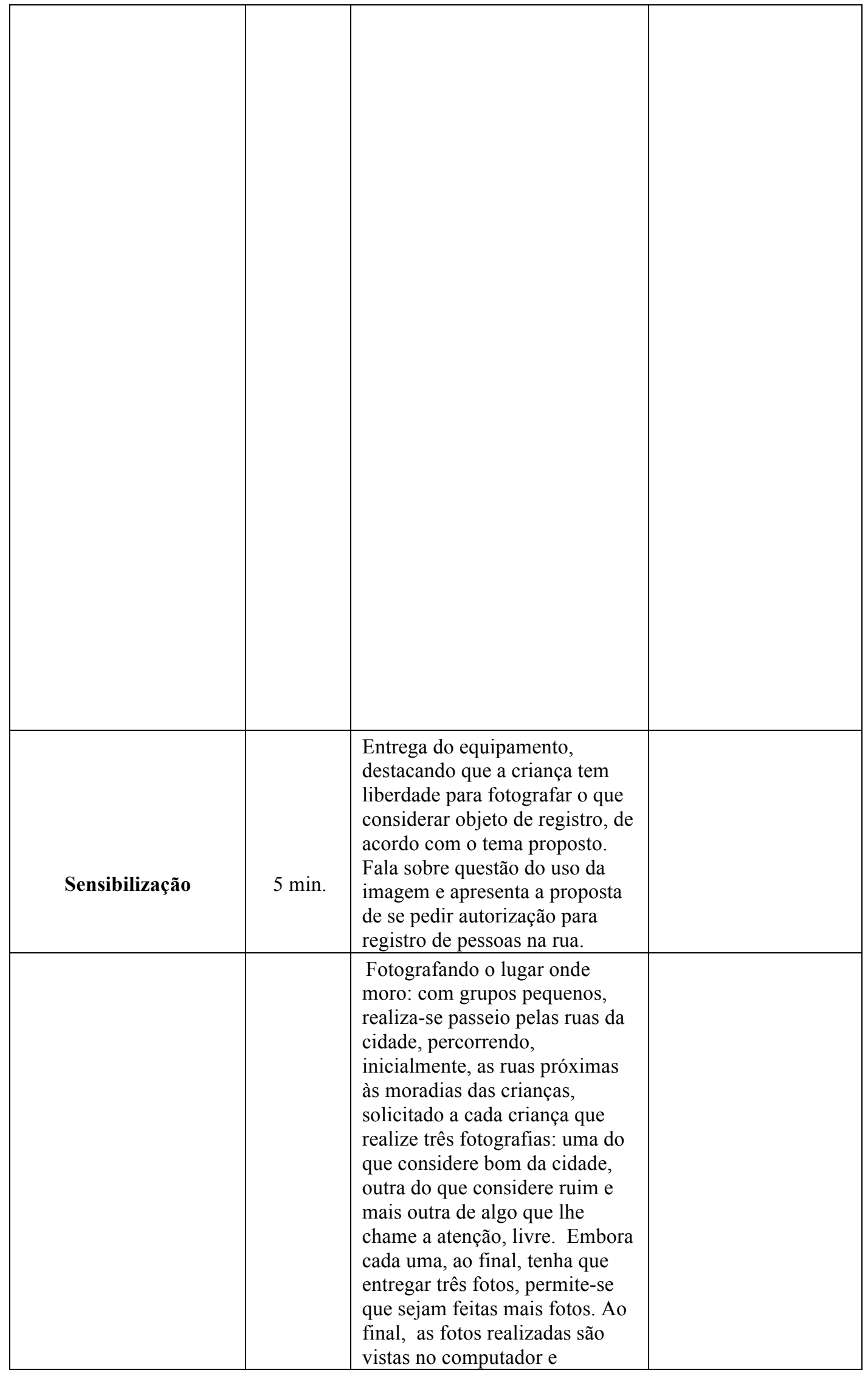




\begin{tabular}{|c|c|c|c|}
\hline Criação & $1 \mathrm{~h} 30 \mathrm{~min}$ & $\begin{array}{l}\text { selecionadas pelas crianças, } \\
\text { bem como discutidas, a partir } \\
\text { das seguintes questões : } \\
\text {-Como foi a experiência de } \\
\text { percorrer esse trajeto. (aguarda } \\
\text { resposta e depois pergunta Você } \\
\text { sentiu cheiros? Que cores } \\
\text { destacaram? Barulhos? Viu algo } \\
\text { novo?) } \\
\text {-O que sentiu ao segurar a } \\
\text { máquina e realizar o registro? } \\
\text {-Descreva para mim cada uma } \\
\text { das imagens (o que está } \\
\text { presente nela que você vê) } \\
\text {-O fotografado o faz lembrar } \\
\text { alguma experiência que teve } \\
\text { anteriormente? } \\
\text {-Na imagem sobre algo ruim, } \\
\text { você, o que está sendo narrado, } \\
\text { o incomoda no dia a dia? Por } \\
\text { quê? } \\
\text {-Na imagem sobre algo bom, } \\
\text { você tem a oportunidade de ver } \\
\text { e viver isso no dia a dia? }\end{array}$ & $\begin{array}{l}\text { Uma máquina } \\
\text { fotográfica digital } \\
\text { para cada } \\
\text { participante. }\end{array}$ \\
\hline Fechamento & $\begin{array}{l}\text { Não mais } \\
\text { que } 40 \\
\text { min. }\end{array}$ & $\begin{array}{l}\text { Acerta os detalhes para o } \\
\text { próximo encontro e faz uma } \\
\text { avaliação do dia. }\end{array}$ & \\
\hline
\end{tabular}

\section{Encontro 3}

\begin{tabular}{|c|l|l|l|}
\hline ETAPA & TEMPO & \multicolumn{1}{|c|}{ ATIVIDADE } & MATERIAL \\
\hline Integração & $5 \mathrm{~min}$. & $\begin{array}{l}\text { Caça ao tesouro: uma pessoa } \\
\text { coloca o prêmio aos } \\
\text { participantes, "tesouro", em um } \\
\text { lugar, outra pessoa dá as dicas } \\
\text { para que os demais possam } \\
\text { encontrar. Quando o tesouro é } \\
\text { encontrado, o prêmio é dividido } \\
\text { por todos. }\end{array}$ & $\begin{array}{l}\text { Algo para servir de } \\
\text { tesouro. }\end{array}$ \\
\hline Sensibilização & $\begin{array}{l}\text { Título da foto: cada participante } \\
\text { recebe as imagens feitas na } \\
\text { atividade fotografando o lugar } \\
\text { que moro, impressas em papel } \\
\text { fotográfico e elabora um título } \\
\text { para cada foto. }\end{array}$ & $\begin{array}{l}\text { Fotos impressas, lápis } \\
\text { e papel. }\end{array}$ \\
\hline & $\begin{array}{l}\text { Apresentando imagens: nesse } \\
\text { momento cada participante } \\
\text { apresenta aos colegas suas }\end{array}$ & $\begin{array}{l}\text { Papel com as } \\
\text { instruções da } \\
\text { atividade } a \text { imagem }\end{array}$ \\
\hline
\end{tabular}




\begin{tabular}{|c|l|l|l|}
\hline & fotos, destacando a experiência \\
do registro. O educador pode, \\
anteriormente, realizar a leitura \\
das imagens e destacar alguns \\
pontos. As fotos são recolhidas, \\
distribuídas aleatoriamente aos \\
Criação
\end{tabular}

\section{Encontro 4}

\begin{tabular}{|c|c|l|l|}
\hline ETAPA & TEMPO & ATIVIDADE & MATERIAL \\
\hline Integração & $5 \mathrm{min.}$ & Uso livre do computador. & $\begin{array}{l}\text { Mapa com as } \\
\text { referências das } \\
\text { moradias. }\end{array}$ \\
\hline Sensibilização & & $\begin{array}{l}\text { Discussão sobre as } \\
\text { possibilidades de uso do } \\
\text { computador em pesquisas } \\
\text { escolares e trabalhos. }\end{array}$ & \\
\hline Criação & $\begin{array}{l}\text { Apresentação dos textos feitos e } \\
\text { pesquisa na internet sobre } \\
\text { trabalhos de fotógrafos, bem } \\
\text { como formas de apresentação. }\end{array}$ & \\
\hline Fechamento & $\begin{array}{l}\text { Acerto da atividade do próximo } \\
\text { encontro e avaliação. }\end{array}$ & \\
\hline
\end{tabular}

\section{Encontro 5}

\begin{tabular}{|c|c|l|l|}
\hline ETAPA & TEMPO & ATIVIDADE & MATERIAL \\
\hline Integração & $5 \mathrm{min.}$ & $\begin{array}{l}\text { Conversa no caminho, dentro } \\
\text { do carro. }\end{array}$ & \\
\hline Sensibilização & & $\begin{array}{l}\text { Apresentação da proposta de } \\
\text { cada exposição visitada. }\end{array}$ & \\
\hline Criação & $\begin{array}{l}\text { Passeio pelas galerias, } \\
\text { destacando a forma como os } \\
\text { trabalhos artísticos foram }\end{array}$ & \\
\hline
\end{tabular}




\begin{tabular}{|c|c|}
\hline & apresentados. \\
\hline Fechamento & $\begin{array}{l}\text { Chuva de ideias sobre como os } \\
\text { trabalhos podem ser } \\
\text { apresentados e acerto dos } \\
\text { detalhes dos próximos } \\
\text { encontros. }\end{array}$ \\
\hline
\end{tabular}

\section{Encontro 6}

\begin{tabular}{|c|c|c|c|}
\hline ETAPA & $\begin{array}{c}\text { TEMPO } \\
2 \mathrm{~h} \\
\end{array}$ & ATIVIDADE & MATERIAL \\
\hline Integração & $5 \mathrm{~min}$. & Uso livre do computador. & $\begin{array}{l}\text { Mapa com as } \\
\text { referências das } \\
\text { moradias. }\end{array}$ \\
\hline Sensibilização & & $\begin{array}{l}\text { Teia da Vida (origem } \\
\text { desconhecida): nesta atividade o } \\
\text { grupo forma um círculo e uma } \\
\text { pessoa começa falando uma } \\
\text { palavra que represente o que } \\
\text { achou mais legal da experiência } \\
\text { da oficina, segurando um rolo } \\
\text { de barbante e passa para outra } \\
\text { pessoa. Ao final, a facilitadora } \\
\text { destaca a nossa conexão, o que } \\
\text { acontece se uma pessoa solta o } \\
\text { fio. }\end{array}$ & Barbante. \\
\hline Criação & & $\begin{array}{l}\text { As imagens são vistas e } \\
\text { discutem-se as formas de } \\
\text { apresentação delas. }\end{array}$ & $\begin{array}{l}\text { PC com internet para } \\
\text { crianças. }\end{array}$ \\
\hline Fechamento & & & \\
\hline
\end{tabular}

\section{Encontro 7}

\begin{tabular}{|c|c|l|l|}
\hline ETAPA & TEMPO & \multicolumn{1}{|c|}{ ATIVIDADE } & MATERIAL \\
\hline Integração & $5 \mathrm{~h}$ min. & $\begin{array}{l}\text { Visualização das imagens } \\
\text { realizadas na oficina e } \\
\text { aproximação por temas e } \\
\text { questões provocadas pela leitura } \\
\text { de imagens. }\end{array}$ & $\begin{array}{l}\text { Fotos impressas, } \\
\text { mural de metal e } \\
\text { imãs. }\end{array}$ \\
\hline Sensibilização & $\begin{array}{l}\text { Visualização de trabalhos } \\
\text { divulgados na internet. }\end{array}$ & $\begin{array}{l}\text { Computador com } \\
\text { acesso à internet }\end{array}$ \\
\hline Criação & $\begin{array}{l}\text { Criação de peças para uma } \\
\text { possível exposição, visita ao } \\
\text { Ponto de memória para } \\
\text { conhecer um local onde se } \\
\text { trabalha com a memória da } \\
\text { cidade e foi realizada uma } \\
\text { exposição. }\end{array}$ & \\
\hline
\end{tabular}




\begin{tabular}{l|l|l} 
Fechamento & & Avaliação do dia e lanche.
\end{tabular}

\section{Encontro 8}

\begin{tabular}{|c|c|c|c|}
\hline ETAPA & $\begin{array}{c}\text { TEMPO } \\
2 \mathrm{~h} \\
\end{array}$ & ATIVIDADE & MATERIAL \\
\hline Integração & & $\begin{array}{l}\text { Visualização de fotos de toda a } \\
\text { oficina. }\end{array}$ & $\begin{array}{l}\text { Projetor e } \\
\text { computador }\end{array}$ \\
\hline Sensibilização & & $\begin{array}{l}\text { Apresentação do trabalho feito } \\
\text { no encontro anterior. }\end{array}$ & $\begin{array}{l}\text { Painel com história, } \\
\text { imagens. }\end{array}$ \\
\hline Criação & & $\begin{array}{l}\text { Elaboração de peças sobre as } \\
\text { imagens. }\end{array}$ & Folha e caneta \\
\hline Fechamento & & $\begin{array}{l}\text { Avaliação oral e espontânea das } \\
\text { atividades feitas. }\end{array}$ & \\
\hline
\end{tabular}




\section{APENDICE F- Termo de autorização de uso de imagem}

$\mathrm{Eu}$ ,CPF

, RG

depois de conhecer e entender os objetivos, procedimentos metodológicos, riscos e benefícios da pesquisa e atividade pedagógica, bem como de estar ciente da necessidade do uso de minha imagem e/ou depoimento, AUTORIZO, através do presente termo, a realização das fotos que se façam necessárias por , participante da

Oficina Imagens da cidade, fotografando o ambiente. A oficina está sob a responsabilidade de Fernanda Fagundes Alves como parte das ações de pesquisa sob orientação da professora Dra. Claudia Pato, para o mestrado em educação da Universidade de Brasília-UnB.

Ao mesmo tempo, libero a utilização destas fotos para fins científicos, de estudos e de divulgação (livros, artigos, slides, transparências e exposições), em favor dos participantes da oficina e da pesquisadora, obedecendo a princípios da ética e da responsabilidade.

Brasília,__ de

e de 2012

Responsável pela oficina

Sujeito participante do registro fotográfico

Responsável Legal (Caso o sujeito seja menor de idade) 